\title{
SOCIAL ENTREPRENEURSHIP AND SOCIAL ENTERPRISE PHENOMENON: ANTECEDENTS, PROCESSES, IMPACT ACROSS CULTURES AND CONTEXTS
}

\author{
Edited by \\ Marzena Starnawska \\ Agnieszka Brzozowska
}

Volume 14 Issue 2

2018 


\section{Contents}

Editorial Paper. Social Entrepreneurship and Social Enterprise Phenomenon: Antecedents, Processes, Impact across Cultures and Contexts

Marzena Starnawska, Agnieszka Brzozowska

Bricolage and Social Entrepreneurship to Address Emergent Social Needs:

A "Deconstructionist" Perspective

Lamberto Zollo, Riccardo Rialti, Cristiano Ciappei, Andrea Boccardi

Unpacking Social Entrepreneurship: Exploring the Definition Chaos and Its Consequences in England

Tanja Collavo

A New Runway for Journalists: On the Intentions of Journalists to Start Social Enterprises

Huei-Ching Liu, Ching Yin Ip, Chaoyun Liang

Social Initiatives in Food Consumption and Distribution as Part of Sustainable Consumption and Sharing Economy

Katarzyna Bachnik, Justyna Szumniak-Samolej

Book Review

Tadeusz Falencikowski 


\section{Editorial Paper}

\section{Social Entrepreneurship and Social Enterprise Phenomenon: Antecedents, Processes, Impact across Cultures and Contexts}

\section{Marzena Starnawskaํ, Agnieszka Brzozowska²}

\section{INTRODUCTION}

Social entrepreneurship ${ }^{3}$, as a field of research, has gained enormous interest of academics in management and entrepreneurship literature for almost 30 years now. Also, scholars in other intellectual domains like economics, finance, marketing, political science, sociology and few others, have found it fascinating. As a term, it is common in public discourses and has found interest among policy makers, corporations, media, different groups of practitioners and professionals. As a phenomenon it is not new, although the SE term has been only recently coined (Banks, 1972; Drucker, 1979). For far more than two centuries great individuals and groups have tried to tackle the societal challenges, using economic means, such as the Rochdale Pioneers who inspired cooperative ideals, and Florence Nightingale - an English nurse and social activist, who changed the patient care landscape (Nicholls, 2006). Many of the ventures and actions of social initiatives can be traced to the earlier, medieval or even ancient times. Today, social initiatives and social enterprise have emerged in particular countries and regions as a result of

\footnotetext{
1 Marzena Starnawska, Ph.D., Gdańsk University of Technology, Faculty of Management and Economics, Narutowicza 11/12, 80-233 Gdańsk, Poland; e-mail: mstarnaw@wp.pl.

2 Agnieszka Brzozowska, Ph.D., University of Warsaw, Faculty of Management, Szturmowa 1/3, 02-678 Warsaw, Poland; e-mail: abrzozowska@wz.uw.edu.pl.

3 For the purpose of this paper, acronym SE is used for social entrepreneurship.
} 
their historical institutional trajectories, and "social enterprise landscape ZOO" (Young \& Brewer, 2016) has become very heterogeneous.

The interest of management and entrepreneurship research into the phenomenon has resulted in an unprecedented increase in scholarly output. The historical analysis of SE research (Moss, Lumpkin \& Short, 2017) published in key journals and databases shows an increase from one paper to 45 papers published per year between 1990 and 2010. SE centers established in universities like Oxford, Harvard and Cambridge have designed degree programmes, dedicated textbooks, and separate SE conferences, special journals like Social Enterprise Journal, Journal of Social Entrepreneurship and many more have been introduced for educational and publication purposes. SE has become popular as a response to the inabilities of governments and business to solve pressing social problems, including poverty, social exclusion, and environmental issues. All of the above are manifested in the diversity of different SE initiatives. Thus, we express our interest to explain and predict SE and social enterprise as phenomena, to identify related antecedents and outcomes, but also to look into the box of SE processes. This special issue attempts to respond to this interest. Diverse methodological approaches including descriptive, explanatory or exploratory ones are included in the papers in this issue. SE phenomenon is studied on an individual, organizational, and even a macro level. Different data is employed: current or archival data, primary or secondary, referring to different country settings such as Taiwan, Poland, Italy and England. Through the inclusion of such diverse perspectives and context, this issue works as a holistic approach to the phenomenon under analysis.

In the following sections of this paper, we first provide a succinct overview of SE as a phenomenon and research field. We summarize the definitional debate and point to valuable theoretical frameworks for studying SE. Next, we introduce individual authors' contributions to the issue and, finally, we propose further suggestions for future research.

\section{Theoretical and analytical approaches in social entrepreneurship and social enterprise studies}

SE and social enterprise research is strongly practice (i.e., phenomenon) driven and based on anecdotal evidence as the majority of studies are based on exemplary case studies (Alvord, Brown \& Letts, 2014; Mair \& Marti, 2006; Starnawska, 2016a). Most research is descriptive and not contextualized in theory (Dacin, Dacin \& Tracey, 2011), with the exception of some theoretical frameworks we propose further. Many studies evidence small sample cases (Perrini \& Vurro, 2006; Tracey \& Jarvis, 2007; Sharir \& Lerner, 2006; 
Weerawardena \& Mort, 2006). However, large sample studies are rare. For example, Shaw and Carter's (2007) study is an exception based on a large sample of interviews, and there are two large panel and population studies like Global Entrepreneurship Monitor (GEM) or Panel Study of Entrepreneurial Dynamics (PSED). There is no doubt about the lack of large-scale studies and databases of social enterprise and social entrepreneurs too (Dacin et al., 2011). Hockerts and Wustenhagen (2010) call for more longitudinal, even long-term retrospective studies, paralleling to the need for studies on more common large sample research empirical studies. Research infrastructure on SE is weak (Lee, Battilana \& Wang, 2014). This is the result of the lack of databases on social enterprise and social entrepreneurs. Also, there is still a lack of coherent, clear and universal research methods that encompass the SE phenomenon.

There are some discussions about the subject of SE field of research. Dacin and authors (2011) argue that "defining social entrepreneurship through individual-level characteristics, processes will inevitably lead to more discussion and debate about how these characteristics should be." Therefore, although individual level analysis is a universal subject of research, for outlining the scope of the SE phenomenon, the study of entrepreneurs individual features may lead again, like in conventional entrepreneurship research, to unresolved debate about what constitutes the core of SE. The majority of individual-level studies in this field focus on entrepreneurial intentions, which are conducted in the GEM project and north-American PSED. The studies on entrepreneurial personality or specific social entrepreneurial traits are limited (Stephan \& Drencheva, 2017). There is also limited work on values, motives, identity or skills of these. Stephen and Drencheva (2017) suggest that this is due to practitioners narratives of "hero" social entrepreneurs who manage to combat multiple barriers (Borstein, 2004; Leadbeater, 1997). Also, organizational level studies, lead to confusion. As mentioned earlier, there are various SE operation models, specific for particular countries and regions, determined by historical and institutional trajectories (Defourny \& Nyssens, 2012; Ciepielewska-Kowalik, Pieliński, Starnawska \& Szymańska, 2015). Therefore, the heterogeneity of SE is omnipresent, and it is impossible to approach the "social enterprise zoo" (Young \& Brewer, 2016) like a homogenous population of organizations.

The overview of research infrastructure provided by Lee and authors (2014) shows that the majority of key texts in academic literature is focused on an organizational level (76\%) whereas only $16 \%$ employ an individual level. These two distinct streams in the SE literature reflect the two groups of studies undertaken in the SE field. The former individual level focused work is characteristic for mature intermediate studies. Lee and authors (2014) employ this category from Edmondson and McManus (2007) explaining that such studies build on existing research and constructs, and therefore 
allow for testing causal patterns. Whereas organization-level work belongs to a nascent studies group which treats the studied subject as novel, not explained and makes an effort to explore new constructs and patterns.

There are some research opportunities as theoretical contexts are concerned. It is suggested for the SE field to incorporate network related theories, institutional theory and structuration theory (Mair \& Marti, 2006; Dacin et al., 2011; Short, Moss \& Lumpkin, 2009). The network theories include social capital and stakeholder theory. Social enterprise embeddedness in the local community is more pronounced when compared with commercial entrepreneurship (Starnawska, 2017). The importance of building relationships and relying on a social network of entrepreneurs is essential for leveraging resources and building legitimacy across different sectors and different logics. It is also visible that the SE community is being strengthened by many global Foundations, like Ashoka or Skoll, which aim to support them. Moreover, in the end, a network approach can help to explain the potential for generating social impact. The institutional approach suggestion helps to provide insights into the need of SE legitimation as a separate field or subfield of entrepreneurship practice and research. This theoretical framework also responds to the institutional barriers entrepreneurs face, and this is of particular importance for SE organizations that are set between conflicting logics. This includes the emergence of social enterprise in a variety of settings and can be, for example, explained by a social movement's theory. Also, it helps to add to the understanding of the institutionalization of SE as a field of research and practice, and what powers and institutional actors are at play. Moreover, social innovations generate institutional change, and social entrepreneurs can be analyzed as institutional entrepreneurs (Mair \& Matri, 2006; Starnawska, 2017). The focus on the concept of a social entrepreneur as an institutional agent is in line with the structure-agency debate and provides opportunities for discussion on the transformative, change the potential of SE. The institutional and social capital approaches, provide arguments for more engagement of the academic community to employ more interpretivist lenses, through social constructionist approaches, which requires more in-depth and more longitudinal data collection and analysis, with more qualitative approaches, to study the complex and contextual phenomenon of SE (Starnawska, 2016b, 2018).

\section{Research streams in social entrepreneurship and social enterprise}

There are two streams of thought in the current SE research field which are not explicitly distinguished by the academic community. There is a growing pressure to make it a distinct and legitimate field of inquiry. Nicholls (2010) finds SE as at a pre-paradigmatic stage and therefore the SE field of research 
and practice is undergoing a process of maturation (Nicolopoulou, 2014). Other researchers seem not to follow this way of thinking and do not regard the SE field as a domain of its own right, with its own theories (Dacin, Dacin \&Tracey, 2011). This latter, critical approach stems from the already existing fragmentation of the entrepreneurship field, and it questions what additional value to the theory can be provided by studying another, separate field of SE.

Most of the current SE research has focused so far on the definitional debate (Dacin, Dacin \& Matear, 2010), especially in terms of scope and purpose as a subject of activity (Nicolopoulou, 2014). As Dacin and others (2010) summarize, the common issue in all SE definitions is the social aim, but it is still debatable what the "social" element in the concept of SE is (Nicholls, 2006), and there is still some discussions about what is meant by the "entrepreneurship" element. The very juxtaposition of the "social" and "entrepreneurship" generates some essentialist debates between relevant homo politicus and homo economicus (Nyborg, 2000). A high number of definitional debates have been determined by geographical, political and social antecedents, acknowledging the key role of institutional and historical contexts for social enterprise and SE emergence. These contexts vary between countries, regions, continents.

Overall, three main academic schools of thought on social enterprise have developed (Dees \& Anderson, 2006; Defourny \& Nyssens, 2012): social innovation, earned income, and the EMES approach. The first school deals mainly with the notion and phenomenon of social entrepreneurship, whereas the second and the third with the notion and phenomenon of social enterprise. Social innovation focuses on social innovators as individual heroes, change makers and leaders. Here the discourses are focused on "change agency" and "leadership" (Baron, 2007; Nicolopoulou, 2014) and reflect entrepreneurship approaches dominant in the mainstream literature. A lot of this discussion is generated thanks to the Ashoka Foundation promoting its fellows and similar other foundations promoting the discourse on individual change makers (Bornstein, 2004). In this area, there is intense academic work referring to SE (social entrepreneurship). The second school, on "earned income," emphasizes the capability of social enterprise to achieve social aims through earned income. This approach also has roots in America, where in the late 80's there was a need for non-profit organizations to generate revenues to realize their own social mission and to survive in the market at the same time (Dees \& Anderson, 2012). This approach has also dominated the UK agenda of social enterprise, working on non-profits to move away from grant dependency (Tracey, Philips \& Haugh, 2005). Following the effort of scholars from different countries, an EMES project under the leadership of Defourny and Nyssens (2013) put forward nine Weberian "ideal type" criteria, reflecting: social, 
economic and governance dimensions of an "ideal social enterprise" which altogether constitute a constellation of guiding directions for comparative purposes. The EMES spin-off project called International Comparative Social Enterprise Models (ICSEM) has gathered together researchers from more than 50 countries worldwide who have proposed social enterprise models for their countries, to consider their institutional trajectories ${ }^{4}$. A recent attempt at universal typology of social enterprise models has been recently proposed by Defourny and Nyssens (2016) as a key finding from the ICSEM project: entrepreneurial non-profit organizations, social business, social cooperative and public sector social enterprise. Both schools, the second and the third, refer to social enterprise as a notion referring to different types of social enterprises, employing it as an "umbrella" concept encompassing a diverse population of organizations set in different institutional contexts.

Some scholars claim that the literature needs to link the gap between "social" and "entrepreneurship" (Chell, 2007) whereas others consider SE as a version of entrepreneurship (Martin \& Osberg, 20007; Nicolopoulou, 2014). There is no agreement on the domain (field of research), boundaries, and definitions (Short, Moss \& Lumpkin, 2009; Dacin, Dacin \& Matear, 2010; Peredo \& McLean, 2006). The challenges in theory development lie in SE discourses which are conventional and propose idealistic visionary narratives (Steyaert \& Dey, 2010). Thus, moving away from exemplary cases of social enterprise and their leaders, may lead researchers to more critical and advanced approaches to the studies in the field, including the examples on the borders and the margins of the practice field, but also discovering "unsuccessful stories." What is also problematic is that there is a widespread positive image of SE as a phenomenon in academic literature (Dey, 2010, p.121) and the existence of a "high profile" SE with its roots in entrepreneurship studies, as pursued in business schools, feeding on business rhetoric and practices, and emphasizing scaling and vision, as important elements (O'Connor, 2010, pp. 79-82).

\section{Contributions}

The papers in this special issue provide insights into SE and social enterprise across different institutional contexts and countries while employing different methodological approaches and different theoretical frameworks. They help us understand the diversity of the SE phenomenon, and their methodological approaches manifest a richness of research methods that can be applied in the SE field. All of the authors recognize the unique contextualization of social enterprise and SE development in the field of practice and research

The first paper authored by Lamberto Zollo, Ricardo Rialti, Cristiano Ciappei and Andrea Boccardi (2018) "Bricolage and social entrepreneurship to address

4 For almost 40 countries diverse social enterprise models have been proposed. 
emergent social needs: A "deconstructionist" perspective" employ Derrida's $(1976,1988)$ deconstructionist approach to provide insights into bricolage in a SE context. The researchers employ a retrospective longitudinal case study of an Italian SE organization which is one of the oldest non-profit organizations in the world, yet it still impacts upon the social and healthcare landscape in Italy - Misericordia. This organization exemplifies how everyday emergencies are dealt with, which makes it a suitable setting for studying social entrepreneurial solutions and social bricolage as a response manner. The case is chosen as an extreme one (Pettigrew, 1990) against the background of the exploratory nature of the study and the limited research on bricolage in an SE context. They make attempts to see if the bricolage concept can be applied in the SE context. This exploratory case analysis is done through the usage of historical and current data from archival sources, current literature including magazines, reports, communication tools, and transcripts from semi-structured interviews held with Misericordia people. The authors provide a conceptual typology of social bricolage as an entrepreneurial solution to social needs. Five strategies are identified: a rigid efficient arrangement, a flexible and effective arrangement, an inertial momentum arrangement, an elusive arrangement and a structural delay arrangement; as different institutional and entrepreneurial solutions to social needs. The findings show how Misericordia employs these strategies. The contribution of this paper is a conceptual framework on the bricolage approach in addressing emerging social needs. The paper deepens our understanding of possible applications of the bricolage concept in SE studies. It broadens the literature on entrepreneurship and, in particular, SE working with the application of a bricolage approach.

The second paper by Tanja Collavo (2018) - "Unpacking social entrepreneurship: Exploring the definition chaos and its consequences in England" focuses on the organizational level factors determining definitional confusion in SE and social enterprise. Also, the paper aims to explore what the consequences of this state of the art are for social entrepreneurs, social investors, social enterprises and policy makers. The study setting is England, where the SE sector has had a long tradition and has been subject to influences from different actors and organizations in the USA and the EU. The author makes efforts to empirically find out what the long-term effects of this definitional diversity are on multiple stakeholders. The paper uses an exploratory case study approach, where England is treated as a case. For this purpose the author analyses historical secondary data, taken from the period 1995-2016, including archival data such as newspapers, magazines, academic papers, reports produced by government and national think-tanks, to trace the development of the sector in England and factors leading to the current definitional debate. This historical approach is further employed 
in a complementary analysis of archives and content from 69 archived interviews held with different stakeholders from the sector such as employees of sector intermediaries, representatives of charities, social entrepreneurs, academics, and representatives of businesses. The findings help the author to outline three dominant schools of thought in practitioner's discourse: one school on social enterprises as businesses, another on social entrepreneurs as innovators and the last as a community-related phenomenon. These are in line with the 3 schools of thought suggested in the literature on social enterprise (Defourny \& Nyssens, 2013) who, apart from social innovation and the "earned income" school, put forward the aforementioned EMES approach. However, it is interesting to see that the model proposed for England represents an "earned income" school approach (Tracey, Philips \& Haugh, 2005; Teasdale, 2012). In further findings, the author resumes 3 categories of opinions on how the definitional debate impacts the sector. For some, this debate brings opportunities, as it generates inclusiveness and interest in social enterprise. For others, it is a negative phenomenon, as it generates disagreements in the sector, hardens access to funding and creates confusion in making public policies. The study shows that the definitional debate in England raises discussions in practice, and shows that research and practice face similar challenges.

The next paper by Huei-Ching Liu, Ching Yin Ip and Chaoyun Liang (2018) "A new runway for journalists: On the intentions of journalists to start social enterprises" focuses on the entrepreneurial intentions of present and former journalists towards starting a social enterprise. The authors set their hypotheses in the context of the similarities between entrepreneurs and journalists, and analyze how personal traits, creativity and social capital determine the entrepreneurial intentions of journalists. Their research is based on an on-line survey run in social media groups for journalists and covers valid answers from a sample of 401 participants. The findings show no significant influence of personality traits, and the authors explain that this is due to the construction of the research hypotheses based on classic entrepreneurship literature. Another important finding is that creativity and bridging social capital has a positive significant influence on social entrepreneurial intentions. The latter is an essential message as creativity is vital in overcoming the institutional barriers (Dacin et al., 2010) that SE faces. Also, social capital is an important element in SE development, which itself is more strongly emphasized in SE literature, recognizing the role of stakeholders in social enterprise, and a strong pronouncement of embeddedness of social enterprise in a social context. The study throws light on social entrepreneurial intentions among journalists, whom themselves constitute an interesting population. Assigning the role of social entrepreneurs to journalists leads to 
advocacy functions for many societal challenges. It can influence social impact thanks to potentially higher media coverage of social issues. Although the main findings are in line with the mainstream literature on entrepreneurial intentions towards conventional entrepreneurship, the subject and setting of the study in Taiwan is a very inspiring and interesting context, when discussing who social entrepreneurs are.

The last paper by Katarzyna Bachnik and Justyna Szumniak-Samolej (2018) "Social initiatives in food consumption and distribution as part of sustainable consumption and sharing economy" aims to describe and characterize social initiatives in food consumption and distribution in Poland. They present their study on the purposive sample of social initiatives in food consumption and the distribution area. In particular, reference is made to goals, operating models ("ways of acting") and their linkages to sustainable consumption and sharing economy. Four mini-cases of social initiatives in this area, established between 2013- 2016 and located in two main cities in Poland: Cracow and Warsaw, are purposively chosen as the subject of the study. These initiatives are chosen in accordance with sustainability and sharing economy criteria, presented in the paper. The authors use existing secondary data together with related social media and website content material for the case analysis. The described social ventures are grass-roots initiatives, resulting from the bottom up activity of individuals and groups. The key findings of this paper show a variety in their organizational and legal forms, varying from an initiative undertaken by volunteers, a project undertaken by students, to an informal group that set up a non-profit organization. Also, the evidence shows diverse linkages to sustainable consumption and sharing economy across the mini cases. These are involved in purchases of healthy food, promotion of responsible food consumption, being sensitive to food waste issues, motivations to care for the greater good and for nature and for others. The sharing economy dimension is visible not only through sharing food with others but also sharing on the level of building trust and community. The authors plan to undertake a study of organizational and individual behaviors in further quantitative research followed by in-depth interviews with representatives of initiatives in sustainable consumption and sharing economy, to provide more generalizable conclusions. Their minicase study of secondary data shows the urging need for more empirical, wider scale studies. However, it needs to be emphasized that many of these initiatives are novel ones, and reflect new social movements, and are not significant in numbers. Therefore, it comes as no surprise why some research on social enterprise is still anecdotal and SE organizations and ventures are slowly occupying the SE landscape in Poland, i.e., moving towards a variety of sustainability and responsibility related initiatives, beyond a pure welfare 
focus. When, in western European countries, social cooperative enterprise initiatives have become quite abundant, representing new-movements in food, environmental, cultural, educational spheres, in many central and eastern European countries, the rebirth of civil society into social initiatives and social enterprise needs more time for development (Ravensburg, Lang, Poledrini \& Starnawska, 2017).

\section{Future research}

In this part of the paper, we deliver summarizing suggestions for future research directions while recognizing the research gaps identified by authors in this issue. We aim to propose new ideas that can deliver insights into the SE phenomenon. The papers provide findings and conclusions relevant to the practice and research field, and emphasize the value of retrospective case studies; employing the analysis of historical data; the ongoing need of caseand small-scale studies of SE ventures and organizations in contexts where the SE phenomenon is not common; the potential of large-scale studies on individuals and their social entrepreneurial intentions; and the strong potential in the qualitative content analysis of practitioners' discourses as a methodological tool in studying the SE phenomenon.

In their work, Zollo, Rialti, Ciappei and Boccardi (2018) propose a theoretical framework encompassing the typology of social bricolage, depending on social needs and the institutions entrepreneurs cope with, and depending on entrepreneurial and institutional solutions to these social needs. This framework is studied in exploratory, longitudinal case analysis. This study has relevance for SE researchers as it provides a systematic overview of social bricolage approaches to emerging social needs. The chosen exploratory retrospective approach is also a valuable example of how archival data can be employed in a complementary manner with current primary data while studying social enterprise with long traditions. For further research, it is required to validate the proposed framework in other SE organizations and to study the assumption that bricolage is a significant opportunity for social entrepreneurs to address emergent social needs. This paper also works as an exemplary work of retrospective, longitudinal studies on SE organizations. The arguments put forward by Hockerts and Wüstenhagen (2010) regarding the need for such studies, may refer to work on historical and current data as well.

Covallo (2018) shows how qualitative analysis of existing secondary data can contribute to the understanding of the complexity of SE. This methodological approach is rather uncommon and it shows that analyses of current texts of narratives, discourses and, rhetoric, can provide a deeper understanding of the SE phenomenon, as socially constructed. This can also show the power and interplays between a variety of institutional actors 
(Nicholls, 2010). A new stream of literature is emerging and this work is an exemplary example of how narrations of social enterprise can shape SE culture. For tracing the nature of the SE phenomenon, narratives from different actors could be heard to understand the complexity of the studied subject. In this sense, the recognition of practitioners' voices broadens the spectrum of studied populations. It is of particular importance, as social enterprise has not been legally framed in many institutional country contexts. For many countries, social enterprise models have been recognized (Defourny \& Nyssens, 2013), but Covallo (2018) takes a parallel step to analyze practitioners' and other stakeholders' discourses on what social enterprise is. Additionally, T. Covallo's work serves as an exciting example of how qualitative content data analysis can be employed in future studies, in the light of the scarcity of widely available data on SE, and interesting and valuable findings can be generated thanks to the existing discourses and narratives.

The research of Liu, Ip and Liang (2018) confirms existing mainstream literature on conventional entrepreneurship. Their evidence from the journalist community in Taiwan shows that personal traits have no significant impact upon social entrepreneurial intentions. However creativity and bridging social capital are recognized as significant variables. The research is of particular interest, as it does not refer to entrepreneurial intentions among students or graduates or general populations, but is limited to the population of active and former journalists. Further research could potentially explain social entrepreneurial intentions in other professions and be next stage research leading to comparative analyses. The results of this research show the importance of bridging social capital which has practical implications at policy and practitioner level. To extend the SE community, other professional groups can become more and more involved in the societal challenges, which in the end can lead to higher start-up rates of social enterprises, but also strengthen many of them with professional expertise. The findings also confirm the need to employ more network related theories for SE future studies.

Bachnik and Szumniak-Sulej (2018) provide insights into Polish social initiatives in food consumption and distribution, against the background of the understudied nature of the phenomenon. The authors select a purposive sample of diverse cases of such initiatives and provide a descriptive overview of their goals, organization, and links with sustainable consumption and sharing economy. The paper works as exemplary evidence, that the majority of social venture studies are based on small samples of anecdotal evidence, as highlighted at the beginning of the paper. Therefore, having based their research on secondary data, the authors call for further research including primary data collection and more longitudinal observation. As these initiatives are still novel and grass-roots ventures, further qualitative 
and exploratory approaches would be required. As the authors claim, the responsible consumption and sharing economy have become very popular in digital community, and consumer attitudes have a significant impact upon the sustainability of such initiatives.

The work presented in this issue confirms the need for more insightful qualitative studies set in varied institutional contexts, and at the same time for more large-scale studies on populations of nascent or existing social entrepreneurs or social enterprises. In the case of the former, more constructivist and network related approaches can be of further value (Starnawska, 2016a, 2018). In the case of the latter, researchers from different institutional contexts could make attempts at setting the foundations of comparative studies across countries (e.g., Ravensburg et al., 2017) but on large social enterprise populations. Also, with the growing legitimacy of SE in an educational setting (Starnawska, 2018), there lies great potential in evaluating social entrepreneurial attitudes among students and graduates and other populations such as different professions. In parallel, the work presented in this issue shows excellent opportunities in analyzing historical data, since SE is not a novel phenomenon.

\section{Acknowledgment}

The contribution of Marzena Starnawska to this paper and to the editorial work on the issue "Social Entrepreneurship and Social Enterprise Phenomenon: Antecedents, Processes, Impact across Cultures and Contexts" (JEMI 2018) is a result of the project financed by the Polish National Science Centre (Narodowe Centrum Nauki) Dec.no DEC-2011/03/D/HS4/04326.

\section{Acknowledgments}

On behalf of all authors, we would like to express our gratitude to several reviewers who provided their feedback for the submitted papers. We are also extremely grateful to Dr. Anna Ujwary-Gil, Editor in Chief for JEMI, for her invitation to submit a call, her extremely professional support and continuous patience, care. As editors of this thematic issue, we express our thanks to all the authors who submitted their papers to our call.

\section{References}

Alvord, S., Brown, D., \& Letts, S. (2004). Social entrepreneurship and social transformation: An exploratory study. Journal of Applied Behaviour Science, 40(3), 260-281.

Bachnik, K., \& Szumniak-Samolej, J. (2018). Social initiatives in food consumption and distribution as part of sustainable consumption and sharing economy. Journal of Entrepreneurship, Management and Innovation, 14(2), 101-123. 
Banks, J.A. (1972). The Sociology of Social Movements. London: MacMillan.

Baron, D.P. (2007). Corporate social responsibility and social entrepreneurship. Journal of Economics and Management Strategy, 16(3), 683-717.

Bornstein, D. (2004). How to change the world: Social entrepreneurship and the power of new ideas. New York, NY: Oxford University Press.

Chell, E. (2007). Social enterprise and entrepreneurship: Towards a convergent theory of the entrepreneurial process. International Small Business Journal, 25(1), 3-19.

Ciepielewska-Kowalik, A., Pieliński, B., Starnawska, M., \& Szymańska, A. (2015). Social enterprise in Poland: Institutional and historical context, ICSEM Working Papers, 11. Liege: The International Comparative Social Enterprise Models (ICSEM) Project.

Collavo, T. (2018). Unpacking social entrepreneurship: exploring the definition chaos and its consequences in England. Journal of Entrepreneurship, Management and Innovation, 14(2), 49-82.

Dacin, P.A., Dacin, M.T. \& Matear, M. (2010). Social entrepreneurship: Why don't need a new theory and how we move forward from here. Academy of Management Perspectives, 24(3), 37-57.

Dacin, M.T., Dacin, P.A., \& Tracey, P. (2011). Social entrepreneurship: A critique and future directions. Organization Science, 22(5), 1203-1213.

Dees, J.G., \& Anderson, B.B. (2006). Framing a theory of social entrepreneurship: Building on two schools of practice and thought. Research on social entrepreneurship. ARNOVA Occasional Paper Series, 1(3), 39-66.

Defourny, J., \& Nyssens, M. (2013). The EMES approach of social enterprise in a comparative perspective. Working Paper, 12/03, EMES European Research Network.

Defourny, J., \& Nyssens, M. (2016). Fundamentals for an international typology of social enterprise models. ICSEM Working Papers, 33, Liege: The International Comparative Social Enterprise Models (ICSEM) Project.

Derrida, J. (1976). Of Grammatology. Baltimore, MD: Johns Hopkins University Press.

Derrida, J. (1988). Limited Inc. Evanston, IL: Northwestern University Press.

Dey, P. (2006). The rhetoric of social entrepreneurship: Paralogy and new language games in academic discourse. In C. Steyaert \& D. Hjorth (Eds.), Entrepreneurship as Social Change (pp.121-142). Cheltenham UK: Edward Elgar.

Drucker, P. (1979). The Practice of Management. London: Pan Books.

Edmondson, A.C., \& McManus, S.E. (2007). Methodological fit in management field research. Academy of Management Review, 32(4), 1155-1179.

Hockerts, K., \& Wüstenhagen, R. (2010). Greening Goliaths versus emerging Davids - Theorizing about the role of incumbents and new entrants in sustainable entrepreneurship. Journal of Business Venturing, 25(2), 481-492.

Leadbeater, C. (1997). The Rise of the Social Entrepreneur. London, England: Demos. 
Lee, M., Battilana, J., \& Wang, T. (2014). Building an infrastructure for empirical research on social enterprise: Challenges and opportunities. In J. Short (Ed.), Social Entrepreneurship and Research Methods (pp. 241-264). UK: Emerald.

Liu, H.C., Ip C.Y., \& Liang, C. (2018). A New runway for journalists: On the intentions of journalists to start social enterprises. Journal of Entrepreneurship, Management and Innovation, 14(2), 83-100.

Mair, J., \& Marti, I. (2006). Social entrepreneurship research: A source of explanation, prediction and delight. Journal of World Business, 41(1), 36-44.

Martin, R., \& Osberg, S. (2007). Social entrepreneurship: The case for definition. Stanford Social Innovation Review, 5(2), 28-39.

Moss, T.W., Lumpkin G.T., \& Short J.C. (2010).Social entrepreneurship: A historical review and research agenda. In H. Landström \& F. Lohrke (Eds.), Historical Foundations of Entrepreneurship Research (pp. 383-405). Cheltenham, UK: Edward Elgar.

Mueller, S., D'Intino, R.S., Walske, J., Ehrenhard, M.L., Newbert, S.L, Robinson, J.A., \& Senjem, J.C. (2015). What's holding back social entrepreneurship? Removing the impediments to theoretical advancement. Journal of Social Entrepreneurship, 6(3), 245-256.

Nicholls, A. (2006). Social entrepreneurship. In S. Carter \& D. Jones-Evans (Eds.), Enterprise and Small Business ( $2^{\text {nd }}$ ed., pp. 220-242). Harlow, England: Pearson Education.

Nicholls, A. (2010). The legitimacy of social entrepreneurship: Reflexive isomorphism in a pre-paradigmatic field. Entrepreneurship Theory \&Practice, 34(4), 611-633.

Nicolopolou, K. (2014). Social entrepreneurship between cross-currents: Toward a framework for theoretical restructuring of the field. Journal of Small Business Management, 52(4), 678-702.

Nyborg, K. (2000). Homo economicus and homo politicus: Interpretation and aggregation of environmental values. Journal of Economic Behaviour and Organisation, 42(3), 305-322.

O'Connor, E.S. (2010). Location and relocation, visions and revisions: Opportunities for social entrepreneurship. In C. Steyaert \& D. Hjorth (Eds.), Entrepreneurship as social change (pp.79-96). Cheltenham UK: Edward Elgar.

Peredo, A.M., \& McLean, M. (2006). Social entrepreneurship: A critical review of the concept. Journal of World Business, 41(1), 56-65.

Perrini, F., \& Vurro, C. (2006). Social entrepreneurship: Innovation and social change across theory and practice. In J. Mair, J.Robinson, \& K. Hockerts (Eds.), Social Entrepreneurship (pp. 57-86). Basingstoke, UK: Palgrave Macmillan.

Pettigrew, A. (1990). Longitudinal field research on change: theory and practice. Organization Science, 1(3), 267-92. 
Ravensburg, N., Lang R., Poledrini, S., \& Starnawska, M. (2017). Cooperative social enterprises in Western industrialized countries. Proceedings of the 6th EMES International Research Conference on Social Enterprise - Social enterprise for sustainable societies. Leuven, Belgium.

Sharir, M., \& Lerner, M. (2006). Gauging the success of social ventures initiated by individual social entrepreneurs. Journal of World Business, 41(1), 6-20.

Shaw, E., \& Carter, S. (2007). Social entrepreneurship: Theoretical antecedents and empirical analysis of entrepreneurial processes and outcomes. Journal of Small Business and Enterprise Development, 14(3), 418-434.

Short, J., Moss, T., \& Lumpkin, G. (2009). Research in social entrepreneurship: Past contributions and future opportunities. Strategic Entrepreneurship Journal, 3(2), 161-194.

Starnawska, M. (2016a). Social entrepreneurship avenues for the field development through research paradigm intersection: Discussion. Humanities and Social Sciences, 23(4), 241-251.

Starnawska, M. (2016b). Social entrepreneurship research - Challenges, explanations and suggestions for the field development. Problemy Zarzqdzania, 14(3), 13-31.

Starnawska, M. (2017). Przedsiębiorczość społeczna w świetle teorii instytucjonalnej - próba przyczynku teoretycznego. Przedsiębiorczość i Zarzqdzanie, XVIII(12), 149-160.

Starnawska, M. (2018). 'Comprehending' as guiding direction in social entrepreneurship and innovation education: Experts' views. Horyzonty Wychowania. Guiding Directions in Social Entrepreneurship and Innovation Education: Experts' Insights.

Stephan, U., \& Drencheva, A. (2017). The person in social entrepreneurship: A systematic review of research on the social entrepreneurial personality. In G. Ahmetoglu, T. Chamorro-Premuzic, B. Klinger \& T. Karcisky (Eds.), The Wiley Handbook of Entrepreneurship (pp. 205-229). Chichester, UK: Wiley Blackwell.

Steyaert, C., \& Dey, P. (2010). Nine verbs to keep social entrepreneurship research agenda 'dangerous'. Journal of Social Entrepreneurship, 1(2), 231-254.

Teasdale, S. (2012). What's in a name? Making sense of social enterprise discourses. Public Policy and Administration, 27(2), 99-119.

Tracey, P., \& Jarvis, O. (2007). Toward a theory of social venture franchising. Entrepreneurship Theory Practice, 31(5), 667-685.

Tracey, P., Philips, N., \& Haugh, H. (2005). Beyond philanthropy: Community enterprise as a basis for corporate citizenship. Journal of Business Ethics, 58(4), 327-344.

Weerawardena, J., \& Mort, G.S. (2006). Investigating social entrepreneurship: A multidimensional model. Journal of World Business, 41(1), 21-35.

Young, D.R., \& Brewer C.V. (2016). Introduction. In D.R. Young, E.A.M. Searing \& C.V. Brewer (Eds.), The Social enterprise ZOO (pp. 3-14). Cheltenham, UK and Northampton MS, USA: Edward Elgar. 
Zollo, L., Rialti, R., Ciappei, C., \& Boccardi, A. (2018). Bricolage and social entrepreneurship to address emergent social needs: A "deconstructionist" perspective. Journal of Entrepreneurship, Management and Innovation, 14(2), 19-47.

\section{Biographical notes}

Marzena Starnawska (Ph.D.) works at the Faculty of Management and Economics, Gdańsk University of Technology, Poland. Her research, teaching and consulting activities focus on entrepreneurship, social entrepreneurship, social enterprise, social capital, institutional theory, as well as research methodologies. She is an active member of EURAM, EMES, and serves as a reviewer for international journals and research councils.

Agnieszka Brzozowska (Ph.D.) works at the Faculty of Management, University of Warsaw in Warsaw in Poland. She graduated from University of Warsaw with a degree in Psychology. Her research interests focus on immigrant entrepreneurship, the cultural context of entrepreneurial processes and the development of entrepreneurial skills. She is also involved in the Centre for Entrepreneurship at University of Warsaw. 


\title{
Bricolage and Social Entrepreneurship to Address Emergent Social Needs: A "Deconstructionist" Perspective
}

\section{Lamberto Zollo', Riccardo Rialti², Cristiano Ciappei ${ }^{3}$, Andrea Boccardi4}

\begin{abstract}
Social entrepreneurship is one of the most discussed issues in recent management literature. In particular, social entrepreneurship has recently gained the attention of management scholars interested in understanding its sociological and anthropological aspects. This paper focuses on Claude Lévi-Strauss's notion of "bricolage" and the way it can represent a significant opportunity to address emergent social needs. Building on a postmodernist philosophical perspective, namely Jacques Derrida's "deconstructionism," we attempt to unpack the bricolage phenomenon within the social entrepreneurship field. Following the findings of an in-depth longitudinal case study, we provide a theoretical conceptualization of possible entrepreneurial solutions to social needs, exploring the significant role of bricolage that is consequently interpreted as a suitable entrepreneurial opportunity to address particular types of social needs that we shall define, in a way, as emergent.
\end{abstract}

Keywords: social entrepreneurship, bricolage, non-profit organizations, deconstructionism, complexity, emergencies management.

\section{INTRODUCTION}

Entrepreneurship has traditionally represented one of the most explored fields in the managerial literature (Shane \& Venkataraman, 2000; Anderson \& Starnawska, 2008; Garba, Djafar \& Mansor, 2013). Even though a univocally

1 Lamberto Zollo, University of Florence (DISEI - Department of Economics and Management), Via delle Pandette 32, 50127, Florence (Italy); e-mail: lamberto.zollo@unifi.it.

2 Riccardo Rialti, Zollo, University of Florence (DISEI - Department of Economics and Management), Via delle Pandette 32, 50127, Florence (Italy); e-mail: riccardo.rialti@unifi.it.

3 Cristiano Ciappei, University of Florence, University of Florence (DISEI - Department of Economics and Management), Via delle Pandette 32, 50127, Florence (Italy); e-mail: cristiano.ciappei@unifi.it.

4 Andrea Boccardi, University of Florence, , University of Florence (DISEI - Department of Economics and Management), Via delle Pandette 32, 50127, Florence (Italy); e-mail: andrea.boccardi@unifi.it. 
accepted definition of 'entrepreneurship' does not exist yet (Gartner, 1990), entrepreneurial activity has generally been identified as a human activity consisting of "reorganizing the established and crafting the new across a broad range of settings and spaces and for a range of goals such as social change" (Steyaert \& Katz, 2004, p. 182). In this perspective, entrepreneurship literature has focused on the exploration of the role of entrepreneurs in economic growth (Brzozowska, Glinka \& Postula, 2014), on entrepreneurial education (Ciappei, Laudano, Zollo \& Rialti, 2016; Rialti, Pellegrini, Caputo \& Dabic, 2017) and, in addition, on the potential of entrepreneurship in value generation and in the creation of new ventures (Campos, Alvarado Acuña, de la Parra \& Aguilar Valenzuela, 2013; Papzan, Afsharzade \& Moradi, 2013; Zollo, Laudano, Ciappei \& Zampi, 2017a). However, despite the traditional attention of literature on commercial entrepreneurship, as a consequence of the recent attention on sustainable growth and the satisfaction of social needs, such important entrepreneurial topics of research have started to be addressed to social issues and societal challenges too. Hence, social entrepreneurship is emerging as one of the most significant issues within entrepreneurship literature (Mair, Battilana, \& Cardenas, 2012; Zollo, Marzi, Boccardi, \& Surchi, 2015; Zollo, Rialti, Ciappei, \& Pellegrini, 2016b).

Social entrepreneurship has been identified as the form of entrepreneurship characterized not exclusively by the pursuit of economic goals but also by the pursuit of social and environmental objectives (Mair, Battilana \& Cardenas, 2012). Moreover, it has been deemed to be based on collective wisdom and long-term social value creation (Mair \& Marti, 2004; Tan, Williams \& Tan, 2005; Bacq \& Jenssen, 2011). In spite of these significant differences, it is possible to identify a point of contact between traditional or commercial entrepreneurship and social entrepreneurship. In fact, just as commercial entrepreneurs have to arrange a resource-constrained scenario in order to create economic value (Stevenson \& Jarillo, 1990), social entrepreneurs have to gather, rearrange, and reinterpret the available resources for the creation of the social value (Zahra, Gedajlovic, Neubaum \& Shulman, 2009; Di Domenico, Haugh \& Tracey, 2010; Zollo et al., 2016b). In this regard, the typical ability of an entrepreneur to rearrange, reinterpret and exploit the stock of available resources has been assimilated to the anthropological notion of 'bricolage' (Lévi-Strauss, 1966), which represents the main focus of the present research.

Building on these considerations, this paper attempts to explore whether the concept of bricolage may be considered valid in the social entrepreneurship context. Specifically, we will analyze whether bricolage is also a strategy capable of exploiting emerging opportunities to develop solutions to social emergencies. This research, thus, aims at contributing to 
social entrepreneurship literature by exploring the bricolage phenomenon in a contextualized setting, namely social entrepreneurship organizations located in Italy. In this sense, we will study the case of the "Venerabile Arciconfraternita della Misericordia di Firenze" (Confraternity of Mercy of Florence), which is one of the most ancient non-profit organizations in the world and still plays a crucial role in the Italian socio-healthcare scenario (see Zollo, Faldetta, Pellegrini \& Ciappei, 2016a). As a result, a conceptual framework concerning bricolage solutions to address emerging social needs will be theorized.

This paper is structured as follows. Firstly, the theoretical background of bricolage is contextualized within literature on social entrepreneurship. Next, the philosophical perspective of "deconstructionism" is illustrated in order to unpack the bricolage concept in social entrepreneurship. Thirdly, the research setting - the "Venerabile Arciconfraternita della Misericordia di Firenze" - along with the adopted methodology is presented. Then, the empirical findings from the longitudinal case study are discussed along with the exploration of the "social bricolage phenomenon." Finally, implications both at a theoretical and practical level are provided, along with significant avenues for future research.

\section{LITERATURE REVIEW}

\section{Bricolage in social entrepreneurship}

Recently, entrepreneurial bricolage has been considered as one of the leading critical factors for an organization's success and competitiveness, along with the traditional entrepreneurial perspectives of "causation" and "effectuation" (Fisher, 2012; Andries, Debackere \& Looy, 2013; Arend, Sarooghi \& Burkemper, 2015). While causation exists when "an individual entrepreneur decides on a predetermined goal and then selects between means to achieve that goal" (Fisher, 2012, p. 1022), effectuation has been seminally defined by Sarasvathy (2008) as "a logic of entrepreneurial expertise, a dynamic and interactive process of creating new artefacts in the world" (p. 6; see also Sarasvathy, 2001). Building on this, Baker and Nelson (2005) first referred to the notion of entrepreneurial bricolage as "making do by applying combinations of resources at hand to new problems and opportunities" (p. 33), thus stressing its action-oriented and "hands-on" approach (Fisher, 2012, p. 1026; see also George, 2005; Alvarez \& Barney, 2007). Entrepreneurial bricolage is characterized by improvisation and adaptation (Baker, Miner \& Eesley, 2003), resilience, "ritualized ingenuity," experiential memory (Duymedjian \& Rüling, 2010), 
and "refusal to enact" (Di Domenico, Haugh \& Tracey, 2010, p. 685). These features are particularly significant in the dynamic, complex and uncertain entrepreneurship field which is typically and closely connected with social change and societal challenges (Desa, 2012; Pellegrini, Ciappei, Zollo \& Boccardi, 2016). The notion of bricolage was first introduced in Claude Lévi-Strauss's masterpiece, The Savage Mind (1966). This concept has increasingly gained attention in management research (Baker, Miner \& Eesley, 2003; Duymedjian \& Rüling, 2010), and has been increasingly investigated by entrepreneurship scholars (Garud \& Karnøe, 2003; Baker \& Nelson, 2005; Di Domenico et al., 2010; Desa, 2012).

According to Lévi-Strauss's seminal definition (1966, p. 17), bricoleurs overcome environmental constraints due to a scarcity of resources thanks to "making do" of "whatever is at hand," and thanks to the creative recombination of resources for new purposes (Ciborra, 1996; Baker \& Nelson 2005). Specifically, the French anthropologist distinguishes and differentiates bricoleurs from engineers. According to his philosophy, the bricoleur prioritizes opportunities-driven attitudes with resources 'at hand' by creating 'something from nothing' (Lévi-Strauss, 1966) thanks to a reflexive reinterpretation that is derived from their previous experience (Baker et al., 2003; Di Domenico et al., 2010; Zollo, Pellegrini \& Ciappei, 2016c). On the contrary, engineers a priori identify the available resources in order to determine a structure that best fits the contingent environmental events. As a result, it has been assessed that bricoleurs are characterized by the sensemaking ability to implement practical knowledge in a penurious environment (Baker \& Nelson, 2005; Duymedjian \& Rüling, 2010). Thus, they are capable of adapting the "heterogeneous repertoire" (Lévi-Strauss, 1966, p. 17) of already existing resources and reassembling them for new instrumental uses. In other words, bricoleurs "turn back to an already existent set made up of tools and materials, to consider and reconsider what it contains" (LéviStrauss, 1966, p. 18), and they creatively arrange new repertoires that will be instrumentally readapted for new challenges (Duymedjian \& Rüling, 2010).

Because one of the most essential elements of entrepreneurial bricolage is connected to resources, we have deemed it necessary to illustrate the main facets of such a concept. By resources 'at hand' literature we refer to existing organizational mechanisms (Ciborra, 1996) and social network relations (Baker et al., 2003), along with previously learned skills and mechanisms (Hatton, 1989) which constitute the available inventory of the entrepreneur's repertoire (see Moorman \& Miner, 1998; Katila \& Shane, 2005; Duymedjian \& Rüling, 2010). By 'recombination' of resources literature we refer to the original reconciliation of existing organizational mechanisms and to the adjustment, alteration, and arrangement of 
a different combination of resources (Jacob, 1977; Baker \& Nelson, 2005; Garud \& Giuliani, 2013) which aim at recreating the internal disposition of the repertoire's internal parts with a view to a functionally performing repertoire. Such an ingenious recombination enables bricoleurs to exploit the resources latent functions and capacities, thus creating ephemeral rearrangements from the available repertoire and allowing temporary solutions to unexpected contingent emergencies (Lanzara, 1983; Johannisson \& Olaison, 2007). Building on recent literature (Di Domenico et al., 2010), we argue that entrepreneurial bricolage may play a remarkable role in the domain of social entrepreneurship. In fact, entrepreneurs act as social bricoleurs by improvising innovative solutions to immediate complex social problems, thus becoming the agents of change by applying seemingly unfitted resources "at hand" to unexpected social problems (Bacq \& Janssen, 2011). Such an existing gap between available resources and social aim is filled thanks to bricoleurs' ingenious reinterpretation of the vacant function of resources that allows the "creation of something from nothing" (Baker \& Nelson, 2005, p. 336). This interpretative ability enables them to seize multiple 'making do' opportunities in one single resource that they creatively project in an unusual and imaginative combination with other resources, thus creating latent synergic value (Lévi-Strauss, 1966). In this way, the typical use of a resource is disarranged in order to adapt its capacity to seemingly unfitting objectives. As a consequence, it is clear that social bricoleurs share the common features of social entrepreneurs, namely skilful management of unexpected opportunities, spontaneous innovation, improvised risk, resources differently rearranged to social value creation (Peredo \& McLean, 2006; Bacq \& Janssen, 2011). Actually, the "social dimension" of bricolage (Johannisson \& Olaison, 2007, p. 55) becomes extremely important when unpredicted and emergent situations arise and entrepreneurial bricoleurs have to spontaneously improvise an innovative and rapid solution making use of the available repertoire of resources (Di Domenico et al., 2010). Hence, we stress the importance of the social aspects of bricolage such as relational capacity, network implementation, spontaneous cooperative activities aimed at social value creation.

The concepts of social entrepreneurship and bricolage are strictly related to the traditional entrepreneurship's definition "to take into one's own hand" (Tapsell \& Woods, 2010, p. 536; see also Kickul, Griffiths \& Gundry, 2010; Kickul, Bacq \& Garud, 2013; Gundry, Kickul, Griffiths \& Bacq, 2011a). However, on the one hand, social entrepreneurs aim to exploit opportunities in an innovative way in order to address social needs and offer social transformations (Tan, Williams \& Tan, 2005; Mair \& Marti, 2006; Bacq \& Janssen, 2011; Starnawska, 2015; Zollo et al., 2016b; Zollo, Pellegrini, Faldetta \& Rialti, 2017b). On the other 
hand, bricoleurs seek to reorganize and recombine the already available and often neglected resources, by spontaneously applying them to address new opportunities and unpredicted challenges so as to create value (Ciborra, 1996; Baker et al., 2003; Garud \& Karnøe, 2003; Baker \& Nelson, 2005; Pellegrini et al., 2016; Zollo, Pellegrini \& Ciappei, 2016c; Zollo, Rialti, Ciappei \& Boccardi, 2017c). According to Gundry and colleagues (Gundry et al., 2011a; Gundry et al., 2011b), because social entrepreneurs have to constantly cope with resource-constrained environments, their ability to creatively and innovatively combine available resources to solve unexpected problems - which is referred to as bricolage - emerges as crucial in modern economic scenarios (see also Griffiths, Gundry \& Kickul, 2013). Consistently, recent scholars argue that entrepreneurial bricolage may be interpreted as the way modern entrepreneurs "catalyse" social innovation by effectively (1) combining available resources in an ingenious fashion and (2) entering new markets that are ignored by their competitors and seizing the latent profitable and attractive opportunities (see Desa \& Basu, 2013; Kickul, Bacq \& Garud, 2013; Bacq, Ofstein, Kickul \& Gundry, 2015). In this sense, it is possible to assess that the ephemeral social entrepreneurship bricolage strategies emerge when bricoleurs look for sustainable solutions to emergent social problems (Johannisson \& Olaison, 2007; Di Domenico et al., 2010; Desa, 2012).

Building on this rich literature background, the aim of this paper is to study the dynamics of social bricolage in the particular context of non-profit organizations involved in socio-health emergency and urgency activities. To analyze this phenomenon, we will use the philosophical perspective of deconstructionism. The deconstructionist approach, in fact, emerges as particularly adequate and appropriate to critically analyze the way bricoleurs implement their rearrangement of "whatever is at hand" in social contexts. In this sense, the next section illustrates how social bricolage may be interpreted using a destructionist approach.

\section{Social bricolage and deconstructionism}

As stated in the previous paragraphs, the act of "reorganizing the established and crafting the new" appropriately describes entrepreneurial activity (Steyaert \& Katz, 2004, p. 182). When such an activity is turned to social challenges, then social entrepreneurship arises (Tan et al., 2005; Mair \& Marti, 2006). Furthermore, we argued that the social entrepreneurship phenomenon is thoroughly suitable for the notion of bricolage, since it well describes the interpretative ability to reorganize and recombine resources so as to seize 'making do' opportunities in unpredicted challenges, thus creating innovative solutions (Baker et al., 2003; Garud \& Karnøe, 2003; Baker \& Nelson, 2005; Duymedjian \& Rüling, 2010). Due to the fact that the ultimate 
goal of this research is to analyse the recent notion of social bricolage, in this section, we will observe from an epistemological perspective how to unpack the concept in order to deeply understand its principles and dynamics. In this sense, the selected point of observation is the deconstructionist approach, an interpretative approach that has received scarce attention in the managerial literature except for few contributions (Cooper, 1989; Martin, 1990; Kilduff, 1993).

\section{The deconstructionist philosophical approach}

Originally, the expression deconstructionism referred to the post-modern philosophy of Jacques Derrida $(1976 ; 1978 ; 1988)$ who, in line with his complex and elitist language style, counterintuitively described it in this way: "Deconstruction does not exist somewhere, pure, proper, self-identical, outside of its inscriptions in conflictual and differentiated contexts; it "is" only what it does and what is done with it, there where it takes place (1988, p. 141)". Thus, what emerges from this definition is the epistemological function of deconstructionism, which consists of interpreting particular contexts, usually literary texts, characterized by semantic conflicts and differences of concepts that may reveal rhetorical dependencies (Derrida, 1976; Kilduff, 1993). At the beginning, deconstructionism was aimed at questioning the prevailing theory of structuralism (Lévi-Strauss, 1963), thus originating the so-called "structuralist controversy" (Derrida, 1966). In fact, deconstructionism, in its analysis of the Kantian phenomenological purposiveness of a determined structural system, focuses on contingent complexity that causes the structuring and deconstructing effects of a particular system, composed of interacting and conflicting events resulting in the evolution and dynamics of the structure (Pellegrini, Rialti, Ciappei, \& Zollo, forthcoming). In such a perspective, the expected, programmed and prearranged patterns of a structure's internal parts paradoxically constitute its boundaries, mainly because in unpredicted critical contingencies that particular structure cannot be used (Derrida, 1976; 1978).

Even though deconstructionism has been traditionally used in poststructuralist philosophy, such an analytic methodology has also interested management scholars who describe deconstructionism as "an analytic strategy that exposes, in a systematic way, multiple ways a text can be interpreted" (Martin, 1990, p. 340). Hence, in our effort to apply such a methodology to the entrepreneurial setting, the relevant interest refers to the strategic method of deconstructionism that systematically allows the interpretation of a particular social phenomenon. Because social entrepreneurship, and particularly social bricolage, are characterized by the systematic need to responsibly interpret social challenges so as to analytically find the most appropriate strategy (Tan 
et al., 2005; Steyart \& Katz, 2004; Bacq \& Janssen, 2011), deconstructionism seems extremely relevant in this scenario. Specifically, the importance of deconstructionism for social bricolage is in relation to the possibility of bringing about a 'dialogue' between external unpredicted contingencies and the prearranged patterns of a structured system's internal parts (Derrida, 1988; Duymedjian \& Rüling, 2010). Consequently, what Lévi-Strauss (1966) called 'repertoire', or stock of resources, may be interpreted in Derrida's terms as the phenomenological 'centre' of a unique and structured system composed of internal parts. Hence, we are led to argue that Derrida's deconstructionism can explain the assembling process of bricolage, recently defined as "a continual process of testing, permutation, and substitution of pre-existing objects" (Duymedjian \& Rüling, 2010, p. 138). Building on these theories, we may argue that social bricoleurs deconstruct prearranged patterns of available resources "at hand", and then they reinterpret the interactions and meaning of such resources, finally associating new functions with the existing repertoire to face critical and unexpected social events.

The deconstructionist approach can be analysed in sequential phases (Martin, 1990; Kilduff, 1993), namely: (1) individuate an emergent complex dichotomy among distinct elements of a system, focusing the attention on the suppressed or the excluded elements; (2) interpret the elements' contradictory dichotomy so to allow a vacant functional meaning of the excluded elements to arise; (3) fill such a semantic void by deconstructing the original system thanks to the iterative replacement of the elements' functional meaning; (4) temporally reconstruct the whole system of elements to implement a reinterpretation of the functional meaning, thus addressing the emergent complexity; (5) terminate such a deconstructionist process once the critical contingency has been addressed and the original status quo of the system is restored. To apply this theoretical construct to social entrepreneurship, and particularly to social bricolage, we begin with the first phase of deconstructionism, where unpredicted contingent social events create a critical contrast to the entrepreneurs' existing repertoire and its available resources. Because we stated that social bricoleurs refuse to "enact" thanks to their improvisation, creative, interpretative, and rearranging ability (Di Domenico et al., 2010; Desa, 2012), the second phase of deconstructionism is primarily concerned with a "making do" opportunity that social bricoleurs seize in the contingent complexity by reinterpreting the unused resources' function; this may give an innovative meaningful use to that resource. Then, social bricoleurs iteratively rearrange the available resources to ultimately create particular latent synergic relationships within the existing repertoire. In this way, the constraining gap between unexpected contingent events and a seemingly useless stock of resources is filled. It is in this phase 
that the social bricoleur becomes a "deconstructionist" in reinterpreting the functional process of resources' sub-groups. Consequently, the emergent threatening contingency becomes an improvised social opportunity thanks to the spontaneous reinterpretation of rearranged resources aimed at coping with unexpected social emergencies (Johannisson \& Olaison, 2007). Finally, social bricolage must stop the deconstructionist process and re-establish the normal functioning of the repertoire of resources, because what we may call bricolage deconstructionism has to come to an end once the critical event has been successfully managed (Martin, 1990; Kilduff, 1993).

In this paper, we interpret bricolage deconstructionism as an effective entrepreneurial solution to social emergencies. In the following section, we conceptualize a theoretical framework that highlights the different typologies of emergent social needs and the related entrepreneurial solutions.

\section{Social bricolage in a deconstructionist perspective}

Moving from the main characteristics of the deconstructionism approach, the main features of deconstructionism that may be applied to social bricolage refer to (1) the relations and the interactions between the resources' vacant functions; (2) the analytic reinterpretation of the resources' latent meaning; (3) the systematic reconstruction of hidden purposes, and (4) the innovative use of the resources' functions to creatively tackle unexpected social challenges by means of the repertoire of already existing resources (Martin, 1990; Kilduff, 1993). Because social bricolage deals with the complexity of the environmental and entrepreneurial scenario deriving from - (1) the seemingly inadequate repertoire of the available resources; (2) the dichotomy between unexpected social contingencies and such resources and, finally; (3) the bricoleur's ability to reassemble the available resources, thanks to their reinterpretation of their functional value - it can be argued that social bricolage may be interpreted as a particular type of deconstructionism. Precisely, deconstructionism enables social entrepreneurs to refuse "enacting," which is often due to unexpected emergencies, and therefore seizing, in such a contingent complexity, "making do" opportunities thanks to the latent function of resources "at hand" (Lévi-Strauss, 1966). It is clear that bricolage deconstructionism becomes particularly relevant in emergency, dynamic, nonlinear, and uncertain situations which typically depict the entrepreneurial and organizational scenario as a complex system (Stacey, 1995; Morel \& Ramanuajam, 1999; Pellegrini et al., 2016). The social and deconstructionist facets of bricolage may be considered as instances of complex system dynamics (Stacey, 1995), because bricolage specifically refers to the self-organization dynamic defined as the "spontaneous creation of complex structure as a result of the dynamics of the system" (Morel \& 
Ramanuajam, 1999, p. 280). The notions of spontaneity and self-organization are common to social bricolage, particularly when related to "emergency entrepreneurship," the latter being defined as a spontaneously coordinated and self-organized collective ephemeral effort made to cope with the challenges of environmental, social emergencies (Lanzara, 1983; Ciborra, 1996; Johannisson \& Olaison, 2007). As a result, temporary and reconstructed repertoires of resources arise from the social bricoleur's re-interpretative ability to address emergent and unexpected social issues. Hence, because of the deconstructionist perspective, social bricoleurs can innovatively interpret the variety of resources to reconfigure interactive relationships, thus revealing the already existing but latent synergic value of the enterprise's repertoire.

\section{A theoretical reassuming framework of entrepreneurial solutions to address emergent social needs}

In this paper, as addressed by our research question, we want to highlight how social bricolage may represent a suitable entrepreneurial solution to social needs. For this, we have tried to conceptualize a framework illustrating possible social bricolage behaviors capable of addressing the several typologies of social needs. The proposed behavior will also be explored in relation to several kinds of solutions to the problem (see Figure 1).

\section{Absolute Social Bricolage}

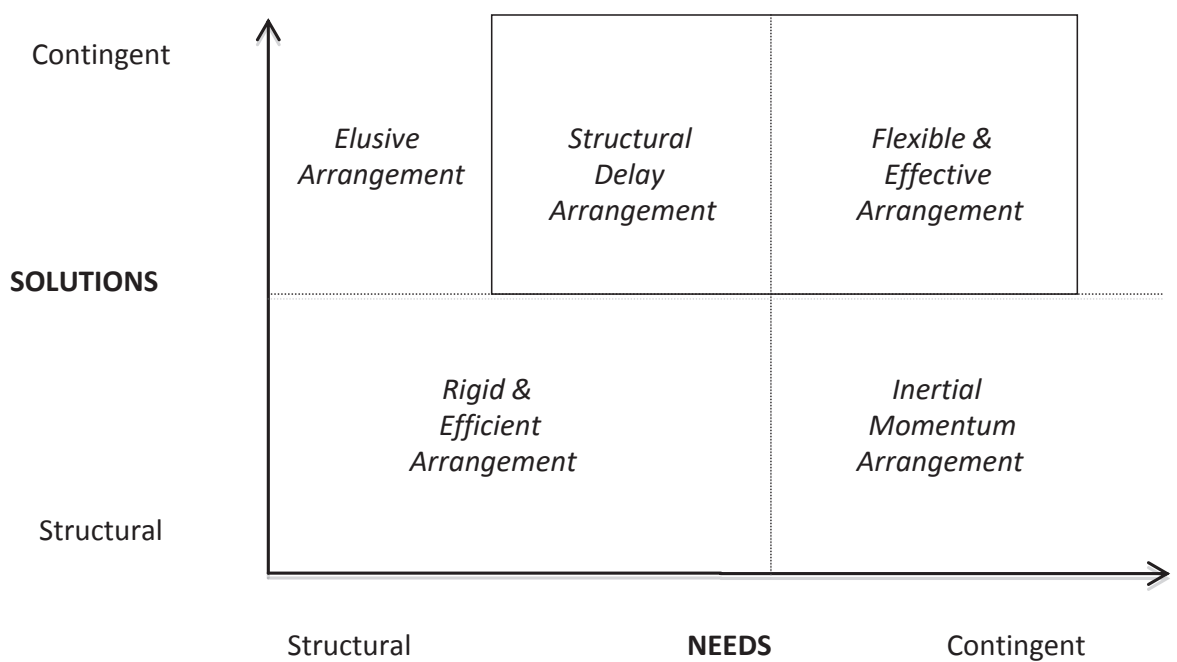

Figure 1. A theoretical framework of social bricolage 
Building on Lévi-Strauss (1966), we have applied the opposition between ,structure' and ,event' in relation to social needs and entrepreneurial solutions. We choose to use the notion of 'contingency' instead of 'event' because the former refers to a more general conceptual framework while the latter has been predominantly developed within the marketing communication literature. However, the notion of 'contingency' is almost the equivalent of event since we refer to contingent social needs that are unexpected and improvised, and require immediate solutions. Moreover, contingent needs do not require structural change but ephemeral and ad hoc interventions. Hence, in order to respond to contingent social needs, resources' redundancy is more important than efficiency.

Our first theoretical classification, which is represented in the horizontal axis, refers to the typologies of social needs that entrepreneurs or institutions have to cope with. It is possible to classify social needs as structural or contingent. Structural social needs have to be satisfied in the long term and require efficient solutions in order to guarantee sustainability, while, contingent social needs can be defined as temporary, unpredictable, and extraordinary in their manifestation.

Our second theoretical classification, represented on the vertical axis, refers to the typologies of entrepreneurial and institutional solutions to social needs. Two types of solutions have been identified - structural and contingent. The structural solutions are efficient and strategic, and last longterm thanks to routine processes, organizational consolidation, and balanced development resulting in qualitative growth. On the other hand, contingent solutions are temporary, unpredicted, and immediate solutions that guarantee entrepreneurial resilience to urgent criticalities. For these solutions, the main features of bricolage are more important than structural efficiency (Baker et al., 2003; Garud \& Karnøe, 2003; Baker \& Nelson, 2005). Indeed, adaptability, improvisation, and resilience are evidently more relevant when social entrepreneurs have to cope with unexpected social problem or emergencies.

At this point, we have conceptualized four possible arrangements between social needs and the corresponding solutions. Mostly, according to our framework, structural social needs require structural solutions, whereas contingent social needs require contingent solutions. Nevertheless, we also analyze criticalities in relation to mixed solutions. The possible social bricolage behaviors to address both structural and contingent needs are the following: 1) Rigid Efficient Arrangement: Firstly, when structural solutions address structural needs, we conceptualize an arrangement that pursues efficiency, permanence, focalization, and stability. This kind of response strategy is possible due to the aforementioned processes of routines, consolidation, and balanced development typical of structural responses 
(Stacey, 1995; Morel \& Ramanuajam, 1999; Johannisson \& Olaison, 2007). We interpret such an area as a 'rigid and efficient arrangement.'

2) Flexible and Effective Arrangement: Secondly, when contingent entrepreneurial solutions address contingent social needs, we conceptualize an arrangement that aims at efficacy and effectiveness, and transitory and improvised processes characterized by a 'ritualized ingenuity' (Lévi-Strauss 1966; Duymedjian \& Rüling 2010). In this area, entrepreneurial solutions refer to effective interventions on external contingencies in order to seize 'making do' opportunities and avoid the threat of 'refusal to enact', although the outcomes will not be strictly 'engineered' (Ciborra, 1996). We interpret such an area as a 'flexible and effective arrangement' and it typically refers to the Absolute Social Bricolage area of our framework.

3) Inertial Momentum Arrangement: Thirdly, when structural solutions address contingent social needs, we conceptualize an arrangement that, notwithstanding the actual new and different contingency, pursues efficiency through unnecessary focalization and outcomes, permanency of obsolete structures, and inappropriate stability (Lévi-Strauss, 1966). We interpret such an area as an 'inertial momentum arrangement,' referring to the inertial activity of the structure, and also to external contingencies that cause functional inappropriateness (Zollo et al., 2017c).

4) Elusive Arrangement and Structural Delay Arrangement: Finally, when contingent entrepreneurial solutions address structural social needs, we conceptualize an arrangement that aims at partial, improvised, and pro tempore solutions that postpone the appropriate, but temporarily unavailable, responsibility of structural solutions (Baker \& Nelson, 2005). In such an area, it is possible to individuate two different arrangements elusive and structural delay. The elusive arrangement refers to when the solution equals elusion so as to shift on to others the problem of facing social needs. The latter refers to 'suspension bridge' solutions addressed to new structural needs where the solutions represent a strictly effective response to new social needs that only in their nascent phase may be interpreted as 'events' (Baker et al., 2003; Garud \& Karnøe, 2003). Nevertheless, the 'structural delay arrangement' behavior has been deemed as belonging to the Absolute Social Bricolage area similar to the 'Flexible and Effective Arrangement.'

The nascent phase of a new structure is different from the ephemeral contingency, mainly because it will last in the long term, and this phase may be considered as an event. In such a context, we stress the difference between contingency and event. While the former is temporary, the event may be referred to as a structural need. Hence, we argue that an emergent need is both the need of a contingency and a structure in its nascent phase. We define the notion of 'emergent' as a social need that arises unexpectedly 
and calls for a prompt solution, due to its ephemeral feature or its nascent phase that will become structural.

In the nascent phase, contingent and structural needs show a strong connotation of 'event' and thus require the bricolage arrangement for the appropriate entrepreneurial solutions. In our conceptual framework, social bricolage represents a contingent solution to contingent social needs and a pro tempore solution to structural social needs in the nascent phase (Stacey, 1995; Morel \& Ramanuajam, 1999). This latter case relates to a 'bridge' solution that initiates a future structural solution in marked contrast to the elusive solutions. Consequently, social bricolage's solutions seem appropriate for the 'flexible and effective arrangement' and the 'structural delay arrangement' as well. We define social bricoleurs coping with contingent social needs as 'deconstructionist' because of their temporary perspective focused on the resources' latent meaning and vacant functionality. On the other hand, social bricoleurs providing contingent solutions to structural social needs in the nascent phase are defined as 'constructionists' because of their ability to individuate the ephemeral determinants of nascent structures that will arise in the future.

\section{METHODOLOGY, DATA COLLECTION AND RESEARCH SETTING}

Recently, entrepreneurship research has emphasized the importance of deepening the level of analysis of the social entrepreneurship phenomenon (Chell, 2007; Bacq \& Janssen, 2011). The main reason for this is the scarce quantitative and qualitative analyses of social entrepreneurship due to the relatively recent nature of such a phenomenon (Perrini, Vurro \& Costanzo, 2010). This is particularly evident in recent research on social bricolage ( $\mathrm{Di}$ Domenico et al., 2010; Desa, 2012).

\section{Methodology}

In order to fill the aforementioned literature gap, a longitudinal case study approach has been selected (Van de Ven \& Huber, 1990; Yin, 2013). This methodology allows both the theoretical comprehension of a littleknown phenomenon (Yin, 2013) and the generalization of the findings (Eisenhardt, 1989). Qualitative research is suitable when information is scant about a phenomenon (Eisenhardt, 1989) and when the aim is to develop ideas from the data in order to iteratively link them to theoretical perspectives (Anderson, Sarah \& Jack, 2010).

We started from existing social entrepreneurship and social bricolage theory in order to develop a theoretical framework aimed at guiding the 
empirical analysis (Perrini, Vurro \& Costanzo, 2010; Yin, 2013). To show different typologies of emergencies and related possible solutions, we investigated the consistency between the pre-developed theoretical framework and the evidence emerging from the case study, thus highlighting the advantages of social bricolage. Given the explorative nature of our study and the scarcity of research on social bricolage, we searched for a context that could represent an extreme case (Pettigrew, 1990). In fact, extreme cases identify possible theoretical paradigms usable prevalently in similar contexts and comparable future researches (Perrini et al., 2010). Therefore, the case of one of the ancient non-profit organizations (NPOs) in the world, the "Venerabile Arciconfraternita della Misericordia di Firenze" (Confraternity of Mercy of Florence), represents the empirical setting for the chosen study. The significant historical importance of 'Venerabile Arciconfraternita della Misericordia di Firenze' (hereafter Misericordia) gives us a unique opportunity to study social entrepreneurship and social bricolage. Misericordia is a private NPO pursuing social goals and can be classified as a social entrepreneurial venture according to recent literature (Defourny \& Nyssen, 2010). Misericordia deals with a wide variety of social emergencies every day, which makes it a suitable case study in order to analyze different typologies of emergencies, possible social entrepreneurial solutions, and social bricolage.

The Misericordia of Florence is the oldest Tuscan Voluntary Association dating back to the Thirteenth Century (1244), based in Florence (Region of Tuscany, Italy). Since its foundation, Misericordia has been dedicating itself to numerous charitable works, i.e., the transportation of the sick to hospitals, care of the debilitated and indisposed, burial of the poorest people, and social assistance for needy and poor families. Misericordia has been involved in providing crucial support since the severe plagues that struck Florence in 1325 and for transporting the sick to hospitals and conducting funerals since 1630. Secondly, Misericordia provided assistance during World War II, when its ambulances were indispensable means of transportation and rescue of wounded soldiers. More recently, Misericordia offered crucial help during the flood of 1966 that struck Florence. All this reflects the great importance and utmost usefulness of the historical charity, the hard work, the generosity of Misericordia, and the continuity of such a fundamental societal service.

Nowadays Misericordia is engaged in numerous activities: an ambulance service; a home care for the elderly and the sick; transportation of the sick and donation of blood; interest-free loans of medical equipment; and the organization of funerals and transport of the deceased. Moreover, it has established a foundation to help people with intellectual disabilities, residences for the care of the elderly, and clinics for medical examination and instrumental diagnostics. Finally, Misericordia is able to operate the services of 
Civil Protection and collaborate with other public and voluntary governmental structures, in order to respond to regional or national emergencies. In this way, Misericordia reflects the recent definition of social entrepreneurship (Defourny \& Nyssen, 2010). The specificity of Misericordia consists in its intervention in social emergencies, hence representing a valid case study for social entrepreneurship and particularly for social bricolage. Misericordia faces everyday emergencies, and show adaptability, improvisation, and resilience both at an individual and a structural level (Lévi-Strauss, 1966).

Due to its history and its long-standing activities, Misericordia represents a suitable extreme case to explore the phenomenon of bricolage in social entrepreneurship. Specifically, on the one hand, Misericordia is one of the most ancient social entrepreneurial ventures still in existence and has been operating continuously since 1244 , and in addition, while it has adapted to the changing environment over its long history, it has shown a high level of resilience by never changing its mission. On the other hand, during its long history Misericordia has faced emerging unexpected social needs many times. In this sense, it has also reacted frequently to emergent social needs as a bricoleur rearranging existing resources in an unusual way. Moving on from this, we have considered Misericordia as an extreme case. In particular, the lessons from the analysis of Misericordia's case may also be useful for understanding the dynamics of younger social entrepreneurial ventures and their reactions to emerging social needs.

\section{Data}

According to the literature on extreme longitudinal case studies (Eisenhardt, 1989; Pettigrew, 1990; Van de Ven \& Huber, 1990), we used three categories of sources. In particular, we have selected the three following ones:

1) Internal magazines, annual reports and other external communication tools. Building on Darke and colleagues' research (Darke, Shanks \& Broadbent, 1998), we have selected internal magazines and reports as our preferred source of information. In particular, we have consulted the last ten digitalized volumes of the 'San Sebastiano Journal,' the monthly published by Misericordia in order to inform its stakeholders. Hence, we have analyzed the last ten years of public communication and 16 annual reports (i.e., Misericordia's Sustainability Report), specifically every one produced by Misericordia's accountants since 2000, and the NPO's corporate web site (www. misericordia.firenze.it). Moreover, we have also considered several articles published in a number of Italian Newspaper such as 'La Nazione','La Repubblica' and 'Il Corriere della Sera' and the sections regarding the events concerning the city of Florence.

2) Corporate chronicles and archival material. Museum of Misericordia, located in Florence contains more than seven centuries of history, and 
a historical archive containing about 4000 documents dating from the Fourteenth Century. We have consulted this archival material to gather data on the historical actions of Misericordia and, specifically, an insight on their decision processes and past strategies. The analysis of archival material is in line with best practices for case study methodology (Eisenhardt, 1989).

3) Semi-structured interviews. In order to gather additional data, 24 semistructured interviews were conducted: with the president of Misericordia (1 interview), the general director (3 interviews), two divisional directors ( 5 interviews in total) and fifteen volunteers (15 interviews in total). The interviews were conducted between January 2013 and May 2015. Each interview lasted from one to two hours and all of them were recorded. In total, we have gathered 35 hours of semi-structured interviews that have been transcribed into a 98-page text. To collect data, semi-structured interviews were selected as they allow a better understanding of the dynamics of a phenomenon through discussion with experienced individuals (Wengraf, 2001; Yin, 2013). Moreover, since they are not structured, it is possible to deviate from the original program and ask the experts for more information.

The longitudinal case study was conducted in several stages. Firstly, a preliminary analysis (Perrini et al., 2010) enabled us to reconstruct Misericordia's chronology, from its archival and historical data, in order to better understand its ancient origins, modern developments, and the historical pivotal events. For ultimate data triangulation (Eisenhardt, 1989), the archival and historical data have been compared with the results of the semi-structured interviews and the data from Misericordia's Sustainability Reports. After this preliminary data exploration process, aimed at delineating Misericordia's historical evolution, we investigated the NPO's main interventions in social emergencies that have hit Tuscany. Our aim was to understand the different solutions addressed to social emergencies, in order to analyze the existence of social bricolage in Misericordia.

\section{RESULTS}

Based on the iterative comparison between literature on social bricolage and the empirical findings resulting from the case study, we provide an analysis of the main entrepreneurial and institutional solutions to social needs. Particularly, we have focused on identifying whether Misericordia has applied the four strategies delineated in the proposed framework by looking at examples of social need where such intervention was needed. In this sense, the findings of our research deal with the confirmation of our framework. 
Rigid and efficient arrangement: The institution of 118 national-service

The case study of Misericordia has shown that when structural needs emerge, it is appropriate to implement structural solutions, thus guaranteeing efficiency in the long term (Ciborra, 1996; Johannisson \& Olaison, 2007). This is particularly evident in the creation of the 118 national-service in 1991 by the Italian Governmental Institutions, which refer to the central units of coordination of emergency-urgency societal needs. In particular, in 1991, after the 1990 FIFA World Cup hosted by Italy, the need emerged to centralize all the sanitary emergency services under one umbrella in order to avoid overlapping and wasting of resource during emergencies. Then the Italian government, with law 76 of 31/03/1992, urged all the NPOs operating in emergency services to adapt to new service standards or relinquish their authorization to operate. Before this service was established, each NPO autonomously coordinated the emergency-urgency activities, which resulted, as assessed, in several inefficiencies in time and cost, i.e., the duplication of volunteers and ambulances for a single service, or NPOs' interventions in distant regional areas that could have been addressed by more local NPOs. In order to improve such a decentralized system, a national conjoined system for emergency-urgency social services has been established which is composed of regional NPOs including Misericordia. In this sense, an important element of the deconstructionist perspective has been applied, namely by reinterpreting possible interactions and relations among available regional socio-healthcare actors - which are NPOs and Governmental Institutions - and their conjoint vacant functions (see Martin, 1990; Kilduff, 1993). In this case, the institutional solution has been structural and efficient for a particular stable, generalized, and recurring social need (Zollo et al., 2017c). In these circumstances, a bricolage solution might be inappropriate because the problem involved recurring routines and due to the structural nature of the need (Kilduff, 1993; Johannisson \& Olaison, 2007). Hence, in this situation, Misericordia adapted to the need to develop a rigid structure in order to continue to operate in emergency sanitary services. This is coherent with the hypothesized rigid and efficient arrangement solution.

Flexible and effective arrangement: Evidence from the Florence Flood of 1966 This area refers to contingent social needs that are matched with contingent solutions, an example of which can be represented by Misericordia's intervention in the dramatic flood that hit the city of Florence on November 4, 1966. After several days of uninterrupted bad weather, the river Arno unexpectedly flooded the city. The damage to the city and the Misericordia headquarter was enormous and required the NPO to rearrange its scarce existing resources to cope with the emergency. 
In this case, the social need was contingent, i.e., it was unpredicted and temporary, even if particularly serious. Misericordia implemented a social bricolage solution that was, firstly, immediate and spontaneous for the inhabitants (Duymedjian \& Rüling, 2010); secondly, it was transitory and ephemeral since no organized structure was established (Lévi-Strauss, 1966); thirdly, it was improvised and collective because Misericordia succeeded in deconstructing the community's social relationships, thus activating the Florentines' workforce regardless of their professional occupation and social class (Garud \& Karnøe, 2003); finally, the solution recalled the notion of 'ritualized ingenuity' since it was extremely important to create solidarity networks based on momentary emotionality (Duymedjian \& Rüling, 2010). We define this social bricolage solution as 'deconstructionist' by examining its process (Derrida, 1966; 1976). (1) Initially, an emergent dichotomy between the community social structure and the relative destructive external contingency was analytically individuated; (2) Secondly, Misericordia succeeded in bringing about the population's latent solidarity and its awareness of the problems and difficulties of the time that were endangering its own survival and the persistence of the cultural patrimony; (3) Then, the ordinary social structure was deconstructed by mobilitating the 'existing resources', i.e., the citizens of Florence, and assigning normally inappropriate duties, tasks, and functions to them; actually, citizens at first seemed inadequate to cope with the flood, but thanks to Misericordia's ability to reassemble volunteers' available resources - such as reciprocity, a willingness to collaborate and donate, etc....(see Baran, 2013; Zollo, Faldetta, Pellegrini \& Ciappei, forthcoming) - such a "repertoire" of critical human resources emerged as crucial in dealing with the natural disaster; (4) Consequently, Misericordia was able to reconstruct a solidarity network resulting ultimately in the creation of essential social existence and survival conditions; (5) Finally, once the external critical contingency had been resolved, the bricolage deconstructionist approach was terminated (Derrida, 1976; Martin, 1990; Kilduff, 1993), thus restoring the ordinary social structure of the city. Therefore, Misericordia acted as a bricoleur. In fact, the NPO preferred to act immediately by rearranging the scarce resources to cope with an unexpected social need.

\section{Inertial momentum arrangement: The Genoa Flood of 2014}

During the night of October 10, 2014, the Sturla River flooded some zones of Genoa city center. On the following day, even the Bisagno River, whose stream bed was inappropriately used as a parking lot, flooded. The flood claimed one death, but also caused damage to the city, and in particular, the majority of the centre was covered by mud and the streets were full of 
rubble. The day after the flood, Misericordia was asked by the government to participate in the rescue efforts.

This case of Misericordia highlights an example of an 'inertial momentum arrangement' providing a structural solution to a contingent social need (Lévi-Strauss, 1966; Garud \& Karnøe, 2003) but, in this instance, no social bricolage solution was provided by NPOs, including Misericordia, since the Governmental Institutions decided to intervene by mobilising the 'Protezione Civile' (Civil Defence). This rigid and bureaucratic solution predominantly made use of internal structures of the Protezione Civile, thus resulting in an insufficient intervention because the contingency of the event had not been recognized. A social bricolage solution, with the activation of a solidarity network and a shared participation, as illustrated previously in the Florence flood, might have been more effective (Martin, 1990). The bureaucratic implementation of the Protezione Civile resulted in an ineffectively programmed solution, thus voluntarily avoiding the redundancy of volunteers, people and citizens (Kilduff, 1993; Ciborra, 1996). Hence, redundancy becomes (Baker et al., 2003; Di Domenico et al., 2010), in such a context of contingent social needs, more important than specificity, focusing, and efficiency. Also, in this case, Misericordia's ability to reassemble the "human" available resources - such as citizens and volunteers - may be interpreted as an effective type of deconstructionism thanks to the NPO's reinterpretation of resources' functional value (Derrida, 1976; Martin, 1990; Kilduff, 1993).

\section{Structural delay arrangement and elusive arrangement, some insights on the current evolution of Misericordia health services}

In a context characterized by structural social needs and contingent solutions, there are two possible arrangements, namely the 'structural delay arrangement' and the 'elusive arrangement.' For both arrangements, an example that emerged from the case study refers to the 'reverse subsidiarity' related to the dismantlement of Tuscany welfare (Zollo et al., 2016a; b). Subsidiarity refers to the local institutional network that provides services to the community since Governmental Institutions have to intervene only when the organized community, i.e., the Third Sector, cannot. However, in case of government failure, the Third Sector which is composed of NPOs including Misericordia is able to integrate from the bottom the deficiencies of the State (Zollo et al., 2016b). For example, Misericordia filled socio-health public voids thanks to (a) medical and diagnostic interventions at low prices in comparison with regional tickets; (b) opening of information points aimed at therapeutic and clinic treatment for people in a confused state of mind; (c) mobile medical clinics on NPOs' ambulances for socio-health services; (d) creation 
of touristic emergency medical services; (e) few interventions of civil defence in small environmental contingencies. Hence, the social solution proposed by Misericordia constitutes a contingent solution to structural social needs that can be interpreted as a pro tempore stop-gap measure in comparison with the forthcoming National Health Service's reconstruction (Lévi-Strauss, 1966; Garud \& Karnøe, 2003). The attitude of the Region of Tuscany represents an 'elusive arrangement' in that the institutional measures are not able to satisfy the real needs of citizens or otherwise they represent inappropriate bureaucratic solutions (Zollo et al., 2017c). On the contrary, the temporary intervention of Misericordia is an example of 'structural delay arrangement.' In effect, the solution provided by the NPO is a social bricolage solution to structural social needs in their nascent phase (Kilduff, 1993; Johannisson \& Olaison, 2007). Misericordia activates the repertoire of improvised social relationships by rearranging the available existing resources, thus revealing the resilient aspect of the Third Sector in the presence of social contingencies (Derrida, 1976). We define this type of social bricolage as 'constructionist' - which may be interpreted as the final outcome of the aforementioned deconstructionist approach - because the relatively autonomous solutions of Governmental Institutions are redefining from the bottom an activation of the available existing resources that in the future could result in integrated socio-health solutions between the public sector and Third Sector (Zollo et al., 2017b; c).

\section{CONCLUSIONS, IMPLICATIONS AND LIMITATIONS}

The present research contributes to the stream of literature on social entrepreneurship and bricolage (Chell, 2007; Bacq \& Janssen, 2011). In this sense, our findings provide systematization in a framework of the main bricoleur solutions that social entrepreneurial ventures, such as Misericordia, may select to address an emerging social need (Johannisson \& Olaison, 2007). Specifically, while the existing literature contributes by highlighting the importance of social entrepreneurial ventures adopting bricolage solutions, this research digs deeper into the phenomenon by providing some relevant insights. As an example, our research firstly provides a framework for assessing which kind of solution (more bricoleur oriented or more structured) is more appropriate to address emerging social needs. Secondly, the present research is among the first to be using deconstructionism (Derrida, 1966; 1796) as a lens to better understand how a bricoleur reaction may be implemented by a social entrepreneurial venture. In particular, it highlighted how following a deconstructionist 
approach enables a social entrepreneurial venture to refuse "enacting", which is often related with unexpected emergencies, and how seizing, in such a contingent complexity, "making do" opportunities exploits unusual function of resources "at hand" (Lévi-Strauss, 1966). Hence, the case study of Misericordia of Florence confirms that social bricolage is a suitable solution when adaptability, improvisation, and resilience are more important than structural efficiency (Baker et al., 2003; Di Domenico et al., 2010). In effect, in social bricolage, the redundancy of resources is more significant than specificity and efficiency. As a consequence, as the principal managerial implication we may argue that social bricolage is an entrepreneurial opportunity to address emergent social needs. In our perspective, emergent social needs are both contingent and structural in their nascent phase, as illustrated previously in our theoretical framework. In contingent social needs, a social bricoleur is able to improvise the most effective, immediate, and flexible solution, rearranging the available repertoire of existing resources, and finally refusing to enact in order to find a solution to social contingencies.

The social bricolage approach is also a pro tempore stop-gap measure for structural needs in their nascent phase (Lévi-Strauss, 1966; Garud \& Karnøe, 2003). In this case, social bricolage provides an effective solution to structural social needs that in their ascent phase can be interpreted as "events" (Lévi-Strauss, 1966). Such a solution is temporary and constitutes a "suspension bridge" between the old structure and the new structure that will be created. However, the bricolage solutions to structural needs do not guarantee in the long term the necessary efficiency. Secondly, we identify the emergent social needs as a syncretic category that embraces both contingent needs and structural needs in their nascent phase (Garud $\&$ Karnøe, 2003). These needs are similar to Lévi-Strauss's concept of "event" and are coherent with a social bricolage solution. Thirdly, building on Derrida's deconstructionism, we identify two types of possible social bricolage interventions for the emergent social needs. On the one hand, in order to cope with contingent social needs, social bricoleurs may intervene according to a deconstructionist approach. In this case, because the contingent emergency deconstructs the environmental context, social bricoleurs have to deconstruct their repertoire of available resources in order to create a fitting dialogue with the context. Hence, the most important phases refer to the initial identification of the resources' vacant functions in relation to the external contingencies; then, rediscover the latent potential of available resources by reinterpreting their functional meaning; after such a de-specializing activity, social bricoleurs systematically and temporarily reconstruct the hidden purposes of the existing resources 
(Lévi-Strauss, 1966; Di Domenico et al., 2010). In such a deconstructionist approach the social bricoleur also realizes a reconstructionist activity since they recombine the existing repertoire so as to innovatively use the available resources. However, the main activity is the deconstruction of the stock of resources, thus addressing the environmental deconstruction determined by the external contingency, which may cause the destruction of the status quo.

On the other hand, when the emergent need is structural, even though it is in its nascent phase, social bricoleurs have to implement a constructionist approach. In this case, the bricolage solution exploits both improvisation and adaptability, but the main activity refers to the creation of a temporary bridge toward a new structure. Social bricolage is a pro tempore stop-gap measure that does not exclude the necessity of a consecutive structural solution thus guaranteeing sustainability and efficiency in the long term. Finally, in relation to regional development, our study highlights two types of positive contributions of social bricolage. First, in the case of contingent social needs, an external contingency destroys the social structure and the regional developmental process. So, social bricoleurs do not explicitly trigger the developmental process, but they contrast the entropy of the system potentially resulting from the contingency. Second, in the case of structural social needs in the nascent phase, social bricoleurs activate a structural developmental process by constructing a pro tempore bridge between the old structure and the new one (Baker \& Nelson, 2005).

In short, therefore, apart from the developed framework, the research contribution is related to providing an original interpretation of the bricolage in social entrepreneurship phenomenon thanks to deconstructionism. Due to the results of our empirical analysis, it has been possible to answer the question highlighted in the first section of our research. Based on the case study analysis of Misericordia of Florence, we can distinguish four possible entrepreneurial and institutional solutions to social needs. Specifically, it has been possible to assess the social bricolage solution as a significant opportunity within the social entrepreneurship field, particularly to address emergent social needs (Garud \& Karnøe, 2003). We refer to the efficiency showed by the bricolage solution proposed by Misericordia to overcome the social needs deriving from the 1966 Florence's flood and the almost ineffective solution to Genoa's 2014 flood. Moreover, due to the results of our research, it has been possible to explore the proposed framework through the identification of several kinds of response strategies, which are coherent with the ones proposed in our framework.

In spite of the findings, however, the research has several limitations. In particular, firstly the research is limited regarding the selected methodology

Social Entrepreneurship and Social Enterprise Phenomenon: Antecedents, Processes, Impact across Cultures and Contexts

Marzena Starnawska and Agnieszka Brzozowska (Eds.) 
and the analysis of a single case study. In fact, our paper has evidently many limitations typically related to case study research (Eisenhardt, 1989; Yin, 2013). Secondly, as a consequence of the selected methodology, the results of our explorative research may only be considered preliminary and not fully generalizable. Specifically, the results are valid only for the selected case. Finally, our research can only be considered exploratory research and other research is required to validate our results again. Therefore, future research is needed in order to empirically test our results and further explore the assumption that bricolage may be a significant opportunity for social entrepreneurs in order to address emergent social needs.

\section{References}

Alvarez, S.A., \& Barney, J.B. (2007). Discovery and creation: Alternative theories of entrepreneurial action. Strategic Entrepreneurship Journal, 1(1-2), 11-26.

Anderson, A.R., Drakopolou-Dodd, S., \& Jack, S. (2010). Network practices and entrepreneurial growth. Scandinavian Journal of Management, 26(2), 121-133.

Anderson, A.R., \& Starnawska, M. (2008). Research practices in entrepreneurship: Problems of definition, description and meaning. The International Journal of Entrepreneurship and Innovation, 9(4), 221-230.

Andries, P., Debackere, K., \& Looy, B. (2013). Simultaneous experimentation as a learning strategy: Business model development under uncertainty. Strategic Entrepreneurship Journal, 7(4), 288-310.

Arend, R. J., Sarooghi, H., \& Burkemper, A. (2015). Effectuation as ineffectual? Applying the $3 \mathrm{E}$ theory-assessment framework to a proposed new theory of entrepreneurship. Academy of Management Review, 40(4), 630-651.

Bacq, S., \& Janssen, F. (2011). The multiple faces of social entrepreneurship: A review of definitional issues based on geographical and thematic criteria. Entrepreneurship and Regional Development, 23(5-6), 373-403.

Bacq, S., Ofstein, L.F., Kickul, J.R., \& Gundry, L.K. (2015). Bricolage in social entrepreneurship: How creative resource mobilization fosters greater social impact. The International Journal of Entrepreneurship and Innovation, 16(4), 283-289.

Baker, T., Miner, A.S., \& Eesley, D.T. (2003). Improvising firms: Bricolage, account giving and improvisational competencies in the founding process. Research Policy, 32(2), 255-276.

Baker, T., \& Nelson, R. (2005). Creating something from nothing: Resource construction through entrepreneurial bricolage. Administrative Science Quarterly, 50(3), 329-366.

Baran, M. (2013). The modelling process of the materials management system in a manufacturing company based on the system dynamics method. Journal of Entrepreneurship, Management \& Innovation, 9(2), 79-96. 
Brzozowska, A., Glinka, B., \& Postuła, A. (2014). Role of university in creating entrepreneurial attitudes. Horyzonty Wychowania, 13(26), 51-71.

Campos, H.M., Alvarado Acuña, L.S., de la Parra, J.P.N., \& Aguilar Valenzuela, F.A. (2013). Entrepreneurial orientation in Mexican microenterprises. Journal of Entrepreneurship, Management \& Innovation, 9(3), 5-20.

Ciappei, C., Laudano, M.C., Zollo, L., \& Rialti, R. (2016). Evaluating the quality of entrepreneurial education analysing its ability to increase entrepreneurial attitude and intent of students. 19th Toulon-Verona International Conference (5-6 September). Spain: University of Huelva.

Ciborra, C.U. (1996). The platform organization: Recombining strategies, structures, and surprises. Organization Science, 7(2), 103-118.

Chell, E. (2007). Social enterprise and entrepreneurship towards a convergent theory of the entrepreneurial process. International Small Business Journal, 25(1), 5-26.

Cooper, R. (1989). Modernism, post modernism and organizational analysis 3: The contribution of Jacques Derrida. Organization Studies, 10(4), 479-502.

Darke, P., Shanks, G., \& Broadbent, M. (1998). Successfully completing case study research: Combining rigour, relevance and pragmatism. Information Systems Journal, 8(4), 273-289.

Defourny, J., \& Nyssens, M. (2010). Conceptions of social enterprise and social entrepreneurship in Europe and the United States: Convergences and divergences. Journal of Social Entrepreneurship, 1(1), 32-53.

Derrida, J. (1966). Structure, sign, and play in the discourse of the human sciences. In R. Macksey \& E. Donato (Eds.), The Structuralist Controversy (pp. 247-272). Baltimore, MD: Johns Hopkins University Press.

Derrida, J. (1976). Of Grammatology. Baltimore, MD: Johns Hopkins University Press.

Derrida, J. (1978). Writing and Difference. Chicago, IL: University of Chicago Press.

Derrida, J. (1988). Limited Inc. Evanston, IL: Northwestern University Press.

Desa, G. (2012). Resource mobilization in international social entrepreneurship: Bricolage as a mechanism of institutional transformation. Entrepreneurship Theory and Practice, 36(4), 727-751.

Desa, G., \& Basu, S. (2013). Optimization or bricolage? Overcoming resource constraints in global social entrepreneurship. Strategic Entrepreneurship Journal, 7(1), 26-49.

Di Domenico, M., Haugh, H., \& Tracey, P. (2010). Social bricolage: Theorizing social value creation in social enterprises. Entrepreneurship Theory and Practice, 34(4), 681-703.

Duymedjian, R., \& Rüling, C.C. (2010). Towards a foundation of bricolage in organization and management theory. Organization Studies, 31(2), 133-151.

Eisenhardt, K.M. (1989). Building theories from case study research. Academy of Management Review, 14(4), 532-550. 
Fisher, G. (2012). Effectuation, causation, and bricolage: A behavioral comparison of emerging theories in entrepreneurship research. Entrepreneurship Theory and Practice, 36(5), 1019-1051.

Garba, A.S., Djafar, F., \& Mansor, S.A. (2013). Evidence of opportunity and necessity driven entrepreneurship in Nigeria. Journal of Entrepreneurship, Management \& Innovation, 9(3), 57-78.

Gartner, W. B. (1990). What are we talking about when we talk about entrepreneurship? Journal of Business Venturing, 5(1), 15-28.

Garud, R., \& Karnoe, P. (2003). Bricolage versus breakthrough: Distributed and embedded agency in technology entrepreneurship. Research Policy, 32(2), 277-300.

Garud, R., \& Giuliani, A.P. (2013). A narrative perspective on entrepreneurial opportunities. Academy of Management Review, 38(1), 157-160.

Griffiths, M.D., Gundry, L.K., \& Kickul, J.R. (2013). The socio-political, economic, and cultural determinants of social entrepreneurship activity: An empirical examination. Journal of Small Business and Enterprise Development, 20(2), 341-357.

Gundry, L.K., Kickul, J.R., Griffiths, M.D., \& Bacq, S.C. (2011a). Creating social change out of nothing: The role of entrepreneurial bricolage in social entrepreneurs' catalytic innovations. In J. Katz \& A.C. Colbert (Eds.), Advances in Entrepreneurship, Firm Emergence and Growth (pp. 1-24). Bingley, UK: Emerald Group Publishing Limited.

Gundry, L.K., Kickul, J.R., Griffiths, M.D., \& Bacq, S.C. (2011b). Entrepreneurial bricolage and innovation ecology: Precursors to social innovation? Frontiers of Entrepreneurship Research, 31(19), 3.

Johannisson, B., \& Olaison, L. (2007). The moment of truth - Reconstructing entrepreneurship and social capital in the eye of the storm. Review of Social Economy, LXV(1), 55-78.

Katila, R., \& Shane, S. (2005). When does lack of resources make new firms innovative? Academy of Management Journal, 48(5), 814-829.

Kickul, J., Griffiths, M.D., \& Gundry, L. (2010). Innovating for Social Impact: Is Bricolage the Catalyst for Change. Handbook of Research on Social Entrepreneurship. Cheltenham, UK: Edward Elgar.

Kickul, J., Bacq, S., \& Garud, N. (2013). Catalyzing social innovation: Is entrepreneurial bricolage always good? (summary). Frontiers of Entrepreneurship Research, 33(18), 6.

Kilduff, M. (1993). Deconstructing organizations. Academy of Management Review, 18(1), 13-31.

Lanzara, G.F. (1983). Ephemeral organizations in extreme environments: Emergence, strategy, extinction. Journal of Management Studies, 20(1), 71-95.

Lévi-Strauss, C., Jacobson, C., \& Schoepf, B.G. (1963). Structural Anthropology. New York, NY: Basic Books.

Lévi-Strauss, C. (1966). The Savage Mind. Chicago: University of Chicago Press. 
Mair, J., \& Marti, I. (2004). Social entrepreneurship: what are we talking about? A framework for future research. Working Paper 546, IESE Business School, University of Navarra.

Mair, J., \& Marti, I. (2006). Social entrepreneurship research: A source of explanation, prediction, and delight. Journal of World Business, 41(1), 36-44.

Mair, J., Battilana, J., \& Cardenas, J. (2012). Organizing for society: A typology of social entrepreneuring models. Journal of Business Ethics, 111(3), 353-373.

Martin, J. (1990). Deconstructing organizational taboos: The suppression of gender conflict in organizations. Organization Science, 1(4), 339-359.

Moorman, C., \& Miner, A. S. (1998). Organizational improvisation and organizational memory. Academy of Management Review, 23(4), 698723.

Morel, B., \& Ramanujam, R. (1999). Through the looking glass of complexity: The dynamics of organizations as adaptive and evolving systems. Organization Science, 10(3), 278-293.

Papzan, A., Afsharzade, N., \& Moradi, K. (2013). Entrepreneurial intention determinants: An empirical model and a case of Iranian students in Malaysia. Journal of Entrepreneurship, Management \& Innovation, 9(3), 43-55.

Pellegrini, M.M., Ciappei, C., Zollo, L., \& Boccardi, A. (2016). Finding the extraordinary and creating the unexpected: Perspicacity and genius combined in an entrepreneurial decision-making paradigm. Journal of Management Development, 35(6), 789-801.

Pellegrini, M.M., Rialti, R., Ciappei, C., \& Zollo, L. (forthcoming). Turnaround management and systemic approach: A historical review of the Florentine management school contribution. International Journal of Critical Accounting. Accepted for publication.

Peredo, A.M., \& McLean, M. (2006). Social entrepreneurship: A critical review of the concept. Journal of World Business, 41(1), 56-65.

Perrini, F., Vurro, C., \& Costanzo, L.A. (2010). A process-based view of social entrepreneurship: From opportunity identification to scaling-up social change in the case of San Patrignano. Entrepreneurship and Regional Development, 22(6), 515-534.

Pettigrew, A. (1990). Longitudinal field research on change: Theory and practice. Organization Science, 1(3), 267-92.

Rialti, R., Pellegrini, M.M., Caputo, A., \& Dabic, M. (2017). Entrepreneurial education and internationalization of firms in transition economies: A conceptual framework from the case of Croatia. World Review of Entrepreneurship, Management and Sustainable Development, 13(2-3), 290-313.

Sarasvathy, S.D. (2001). Causation and effectuation: Towards a theoretical shift from economic inevitability to entrepreneurial contingency. Academy of Management Review, 26(2), 243-288. 
Sarasvathy, S.D. (2008). Effectuation: Elements of Entrepreneurial Expertise. New Horizons in Entrepreneurship Research. Cheltenham, UK: Edward Elgar.

Shane, S., \& Venkataraman, S. (2000). The promise of entrepreneurship as a field of research. Academy of Management Review, 25(1), 217-226.

Stacey, R.D. (1995). The science of complexity: An alternative perspective for strategic change processes. Strategic Management Journal, 16(6), 477-495.

Starnawska, M. (2015). Social entrepreneurship and its hybridity determining resource challenges and chances. Studia Oeconomica Posnaniensia, 4(5), 38-53.

Stevenson, H.H., \& Jarillo, J.C. (1990). A paradigm of entrepreneurship: Entrepreneurial management. Strategic Management Journal, 11(5), 17-27.

Steyaert, C., \& Katz, J. (2004). Reclaiming the space of entrepreneurship in society: Geographical, discursive and social dimensions. Entrepreneurship and Regional Development, 16(3), 179-196.

Tan, W.L., Williams, J., \& Tan, T.M. (2005). Defining the 'social' in 'social entrepreneurship': Altruism and entrepreneurship. International Entrepreneurship and Management Journal, 1(3), 353-365.

Tapsell, P., \& Woods, C. (2010). Social entrepreneurship and innovation: Selforganization in an indigenous context. Entrepreneurship and Regional Development, 22(6), 535-556.

Van de Ven, A.H., \& Huber, G.P. (1990). Longitudinal field research methods for studying processes of organizational change. Organization Science, 1(3), 213-219.

Wengraf, T. (2001). Qualitative Research Interviewing: Biographic Narrative and Semi-Structured Methods. Thousand Oaks, CA: Sage Publications Inc.

Yin, R. (2013). Case Study Research: Design and Methods. Thousand Oaks, CA: Sage Publications Inc.

Zahra, S.A., Gedajlovic, E., Neubaum, D.O., \& Shulman, J.M. (2009). A typology of social entrepreneurs: Motives, search processes and ethical challenges. Journal of Business Venturing, 24(5), 519-532.

Zollo, L., Marzi, G., Boccardi, A., \& Surchi, M. (2015). How to match technological and social innovation: Insights from the biomedical $3 \mathrm{~d}$ printing industry. International Journal of Transitions and Innovation Systems, 4(1/2), 80-95.

Zollo, L., Faldetta, G., Pellegrini, M.M., \& Ciappei, C. (2016a, January). Volunteers' behavioral intention in non-profit organizations strategy: A structural equation model. In Academy of Management Proceedings (Vol. 1, p. 12995).

Zollo, L., Rialti, R., Ciappei, C., \& Pellegrini, M.M. (2016b). Factors stimulating social innovation in entrepreneurship: An empirical evidence of interorganizational alliances in Italy. International Journal of Business and Management, 11(5), 12-19. 
Zollo, L., Pellegrini, M., \& Ciappei, C. (2016c). What sparks ethical decision making? The interplay between moral intuition and moral reasoning: lessons from the scholastic doctrine. Journal of Business Ethics, 145(4), 681-700.

Zollo, L., Laudano, M.C., Ciappei, C., \& Zampi, V. (2017a). Factors affecting universities' ability to foster students' entrepreneurial behaviour: An empirical investigation. Journal of Management Development, 36(2), 268-285.

Zollo, L., Pellegrini, M.M., Faldetta, G., \& Rialti, R. (2017b). The sustainable path of social enterprises toward hybridity: Insights from a multiple case study of Italian NPOs. Proceedings of 17th European Academy of Management - ISSN 2466-7498.

Zollo, L., Rialti, R., Ciappei, C., \& Boccardi, A. (2017c). Reframing social entrepreneurship to address unexpected emergent social needs: An entrepreneurial bricolage perspective. Proceedings of 17th European Academy of Management - ISSN 2466-7498.

Zollo, L., Faldetta, G., Pellegrini, M., \& Ciappei, C. (forthcoming). Reciprocity and gift-giving logic in NPOs. Journal of Managerial Psychology. Accepted for publication.

\begin{abstract}
Abstrakt
Przedsiębiorczość społeczna jest jednq z najczęściej poruszanych kwestii w najnowszej literaturze zarzq̨dzania. Szczególnym zainteresowaniem badaczy stały się kwestie zwiqzane z aspektem socjologicznym i antropologicznym przedsiębiorczości społecznej. Prezentowany tekst koncentruje się na pojęciu „brikolażu” Claude Lévi-Strauss's i na sposobie w jaki może to myślenie wpływać na zaspokajenie potrzeb społecznych. Opierajqc się na postmodernistycznej perspektywie filozoficznej, nazwanq przez Jacques'a Derrida „dekonstrukcjq”, Autorzy próbujq przeanalizować zjawisko brikolażu w kontekście przedsiębiorczości społecznej. Na podstawie wyników pochodzących z pogłębionych podłużnych studiów przypadków, Autorzy zaproponowali swojq koncepcję teoretycznq możliwych, przedsiębiorczych rozwiq̨zań w odpowiedzi na potrzeby społeczne, poszukujqc roli brikolażu, która w konsekwencji została zinterpretowana jako odpowiednia szansa na zaspokojenie konkretnych potrzeb społecznych, które powinniśmy definiować, w znaczeniu takim, jakim się pojawiaja.
\end{abstract}

Słowa kluczowe: przedsiębiorczość społeczna, brikolaż, organizacje non-profit, dekonstrukcjonizm, złożoność, zarzq̨dzanie sytuacyjne. 


\section{Biographical notes}

Lamberto Zollo is a Post-Doc Researcher in Management at the University of Florence. His research interests are in strategic management, business ethics and entrepreneurship. His research has been published in several international journals such as Journal of Business Ethics, Management Decision and Journal of Management Development.

Riccardo Rialti is a Ph.D. Student in Management and Business Administration at the University of Florence. His research interests are in Management Information Systems, Big Data, Strategic Marketing and Entrepreneurship. His research has been published in several international journals such as Management Decision and World Review of Entrepreneurship, Management and Sustainable Development.

Cristiano Ciappei is Full Professor of Management at the University of Florence. His research interests are in Strategic Management, Business Ethics and Entrepreneurship. His research has been published in several international journals such as Journal of Business Ethics, Management Decision and Journal of Management Development.

Andrea Boccardi is a Post-Doc Researcher at the University of Florence. His research interests are in Social Entrepreneurship, Business Ethics and NonProfit Organizations. His research has been published in several international journals such Journal of Management Development. 



\title{
Unpacking Social Entrepreneurship: Exploring the Definition Chaos and Its Consequences in England
}

\author{
Tanja Collavo
}

\begin{abstract}
Socialentrepreneurship has always been a contested concept, both within the academic discourse and in practice. A lot of scholarly effort has been put into analyzing the different definitions of social entrepreneurship and the negative consequences that the definitional debate has on the opportunity to advance social entrepreneurship as a research field. Very little is known about what the consequences of the multiple meanings of social entrepreneurship are for people working in the sector. This paper advances knowledge on this topic by looking at the social entrepreneurship sector in England and by investigating through qualitative research methods what sector members think about social entrepreneurship and its unclear boundaries. The results show that there are three different conceptions of social entrepreneurship within the sector in England. However, while everyone agrees on the presence of a definitional debate, opinions on what this means for the sector are several. Some members think it is something positive; some others think it is causing different issues, and a third group considers it as irrelevant.
\end{abstract}

Keywords: social entrepreneurship, definitions, social enterprises, social entrepreneurs, UK, England.

\section{INTRODUCTION}

Social entrepreneurship is a phenomenon that has existed for centuries (Sepulveda, 2015). It has taken the form of either not-for-profits and nongovernmental organizations (NGOs) engaging in trade to support their activities, or of businesses looking after their employees' welfare (Alter, 2007; Sepulveda, 2015; Teasdale, 2012). Furthermore, it has been additionally represented by the new organizational forms surging in different countries

1 Tanja Collavo, DPhil (PhD candidate), Said Business School, Oxford University New College, Holywell Street, OX1 3BN Oxford (UK); e-mail: tanja.collavo@new.ox.ac.uk. 
in the '70s, such as cooperatives and micro-credit institutions (Alter, 2007; Grenier, 2009). Nonetheless, the term "social entrepreneurship" has been in use only for the last 20-25 years, generated by think-tanks, foundations and politicians prevalently based in the U.S. and in the UK (Bacq \& Janssen, 2011; Grenier, 2008; Teasdale, 2012).

Ever since, many articles have been published discussing both the shortcomings of the lack of scholars' agreement on the meaning of social entrepreneurship and the schools of thought that created this situation (Alter, 2007; Bacq \& Janssen, 2011; Choi \& Majumdar, 2013; Dacin, Dacin \& Matear, 2010; Defourny \& Nyssens, 2010; Hoogendoorn, Pennings \& Thurik, 2010; Perrini, 2006). The lack of agreement around a definition of social entrepreneurship is not only academic but also practice-driven (Grenier, 2008; Martin \& Osberg, 2007; Nicholls, 2010; Teasdale, 2012). So, why are there so many different definitions of social entrepreneurship in the world of practice? What are the practical consequences, if any, of the presence of multiple conceptions of social entrepreneurship? For the purpose of this paper, social entrepreneurship will be defined as any action combining the pursuit of social impact with entrepreneurial techniques or business models (Austin, Stevenson \& Wei-Skillern, 2006; Bacq \& Janssen, 2011; Corner \& Ho, 2010).

While the existing literature has already developed many explanations for the pre-paradigmatic state of the sector (Lehner \& Kansikas, 2013; Nicholls, 2010), its focus has prevalently been conceptual rather than empirical (Dacin et al., 2010). Consequently, the scholarly focus has concentrated on the institutional causes of the definitional confusion rather than on the organizational ones. Moreover, very few authors have looked at what the consequences of this situation are for social entrepreneurs, social enterprises, social investors or policy makers. This has generated an important knowledge gap to be addressed. Indeed, it is possible to assume that the lack of a definition does have an impact, at least on the search for talent, on policy making (Peredo \& McLean, 2006) and on organizational strategies and tactics (Dey \& Teasdale, 2016).

This paper addresses this gap by using as a setting the social entrepreneurship sector in England. This is considered as one of the most advanced in the world (Villeneuve-Smith, Temple, Brown, Gregory, \& BMG Research, 2015) and - being subject to influences from the US., the European Union and its own public and private players - it displays a wide variety of conceptions of social entrepreneurship (Huckfield, 2014; Sepulveda, 2015). Therefore, it represents a good setting to explore the long-term consequences on multiple stakeholders of the presence of different definitions of social entrepreneurship, social entrepreneurs and social enterprises. 
The paper is organized as follows. Firstly, it outlines the existing descriptions of social entrepreneurship present in academic papers and their consequences on the advancement of scholarship on the topic as well as on the sector. The next section describes why England was chosen as the setting and how data was gathered from the multiple stakeholders present in the sector. Finally, the paper presents the definitions of social entrepreneurship traced in England and the impact that their multiplicity has on the development of the sector and on its various stakeholders.

\section{LITERATURE REVIEW}

\section{The multiple definitions of social entrepreneurship}

Social entrepreneurship is intrinsically a difficult phenomenon to pin down and describe. Its very nature calls for a combination of institutional logic and activities typical of both the public and business sectors (Lehner \& Kansikas, 2013). As a consequence of such hybridity, it is a concept usually context-related and expressed through very different organizational forms and practices (Huybrechts \& Nicholls, 2012; Kerlin, 2013).

Social entrepreneurs and enterprises operate in a broad range of sectors: from arts and culture to banking, from real estate development to agriculture (Alter, 2007; EKOS, 2014). Furthermore, their hybrid nature can manifest itself as: the solution of challenging problems through innovation; the creation of employment opportunities and/or of skills development for marginalized or disadvantaged people and communities; the creation of businesses and trading activities that generate social impact (Achleitner, Spiess-Knafl, Lutz \& Mayer, 2012; Garrow \& Hasenfeld, 2014; Martin \& Osberg, 2007; Vasi, 2009). This variety makes it difficult to circumscribe the phenomenon, since this may cause the exclusion of essential projects and innovative solutions.

Austin et al. (2006) divided social entrepreneurship definitions between narrow and broad. Narrow definitions limit social entrepreneurship to the application of business activities and skills to organizations active in the third-sector. Broader definitions include within the social entrepreneurship umbrella the whole spectrum of activities from businesses' CSR practices to innovation and entrepreneurialism in NGOs and charities. Looking at what was happening in-between such a wide spectrum, Dacin et al. (2010) identified 37 different definitions of social enterprises and social entrepreneurs, based on multiple dimensions such as innovativeness, creation of social change, embeddedness in a specific community, adoption of virtuous entrepreneurial behaviors, diffused ownership and financial sustainability. The only common trait among these definitions appeared to be the description of social 
entrepreneurs and enterprises as mobilizers of resources, primarily for the creation of a positive social and/or environmental impact (Dacin et al., 2010; Huybrechts \& Nicholls, 2012) and the association of social entrepreneurship with optimism, social change and the creation of a fair and sustainable society (Dey \& Steyaert, 2010).

\section{Origins of the definitional debate}

The multiplicity of conceptions of social entrepreneurship can be traced back to the different theories on what problems it tries to solve (Bacq \& Janssen, 2011; Huybrechts \& Nicholls, 2012). For example, according to some foundations and network organizations such as Ashoka, the remit of social entrepreneurship is to firstly change the citizen sector by making it more efficient and entrepreneurial and then to change the entire society by tackling unjust equilibria (Ashoka UK, 2015; Drayton, 2006; Sen, 2007). For the European Union, instead, social enterprises should be a mechanism to foster citizens' democratic participation in the management of businesses, to revitalize the economy of poorer countries and to improve the employability of marginalized people (Bacq \& Janssen, 2011; Borzaga \& Defourny, 2001; Defourny \& Nyssens, 2010). Different theories of change inevitably lead to different roles attributed to social entrepreneurs and enterprises and, thus, to a stronger or weaker focus on some of their characteristics.

Such a diversity of conceptions is also reinforced by the different cultures, phases of economic development and social contexts of the countries where social entrepreneurship exists as a sector (Kerlin, 2013). Countries, whose first experience with social entrepreneurship was connected with the cooperative movement, prevalently see social entrepreneurship as connected to the shared ownership of economic activities. On the contrary, countries with an individualistic and entrepreneurial culture often gave rise to definitions of the phenomenon based on its disruptiveness (Defourny \& Nyssens, 2010; Kerlin, 2013) or on the need of no-profits to become financially sustainable through trade (Kerlin, 2013; Sepulveda, 2015). Within each geographical context, the definitional debate is usually also further complicated by the presence of several public and private organizations and sometimes even of the government (Kerlin, 2013; Sepulveda, 2015) interested in the sector. In several cases, indeed, organizations operating in the same setting have very different views of social entrepreneurship and on which part of the sector should be given the most attention (Dacin et al., 2010; Huybrechts \& Nicholls, 2012; Nicholls, 2010; Peredo \& McLean, 2006).

Finally, the definitional debate has been constantly revitalized in the last 15-20 years by scholars' interest in it. Several authors have discussed the presence of two, three or sometimes even four schools of thought around 
social entrepreneurship (Dees \& Anderson, 2006; Defourny \& Nyssens, 2010; Hoogendoorn et al., 2010; Mair \& Martí, 2006; Peredo \& McLean, 2006), with the majority agreeing on a "three schools" split. The first school of thought looks at social entrepreneurship as the undertaking of revenue-generating activities from the side of no-profit organizations or as management strategies to create social value. The second school of thought interprets social entrepreneurship in a Schumpeterian tradition, highlighting its innovative side in the pursuit of poverty alleviation and social equality. Finally, the third school of thought investigates social entrepreneurship as the activity of organizations aiming to benefit their own community (Defourny \& Nyssens, 2010; Mair \& Martí, 2006). Most of the studies produced by the different schools have either employed anecdotal evidence or were conceptual. This favored the creation of multiple definitions based on the specific organization or individual analyzed or on the theory developed (Dacin et al., 2010; Hill, Kothari \& Shea, 2010; Peredo \& McLean, 2006).

\section{Consequences of the definitional debate}

Whether created by scholars or practitioners, the multiplicity of conceptions around social entrepreneurship generates tensions and debates on the appropriateness of the existing organizational forms and practices, the location of sector boundaries and the best role for the sector in the wider economic environment (Bacq \& Janssen, 2011). These tensions, in turn, create multiple accepted practices within the sector in three core dimensions - leadership, structure and business model.

With regard to leadership, there are two possible conceptions of social entrepreneurship: one based on concentrated leadership and one based on diffused leadership. Concentrated leadership focuses on the figure of the social entrepreneur, described as an inspiring lone hero, who comes up with novel solutions and relentlessly pursues them (Martin \& Osberg, 2007). Alternatively, it can be applied to organizations pursuing a social object through a traditional corporate or shares-based structure. Diffused leadership is instead the characteristic trait of social enterprises that either have distributed ownership or are seen as part of a community network that, as a whole, achieves social change (Bacq \& Janssen, 2011; Defourny \& Nyssens, 2010).

As far as the legal structure is concerned, the potential forms of social entrepreneurship are several. In some countries, such as the US. or the UK, a specific legal structure exists for the incorporation of those organizations that see themselves as social enterprises (Huybrechts \& Nicholls, 2012). However, this form is not exclusive (i.e., social enterprises can incorporate through different legal forms - from charities to companies limited by shares) 
and, in reality, it is usually adopted by a very small percentage of organizations (Haigh, Walker, Bacq \& Kickul, 2015). In other countries, such as France, Italy, Germany or Spain, the cooperative form appears to be the privileged one for the signaling of a social enterprise status (Defourny \& Nyssens, 2010). In general, in most countries, a social entrepreneurial organization can legally take any form, (Bacq \& Janssen, 2011). Its identification and differentiation from more traditional organizations, therefore, relies on other vehicles such as marketing, campaigning or badges. Furthermore, many options exist for social entrepreneurial ventures even with regard to organizational structure. Indeed, the co-existence of its business-related and social-related activities can happen through integration (when the two produce one another), partial overlap, or complementarity (when business activities generate revenues that sustain the unrelated social-oriented activities) (Alter, 2007; Fowler, 2000).

Finally, with regard to the business model, social entrepreneurial activity is usually placed on a spectrum going from purely nonprofits, engaging in innovative or revenue-generating activities to businesses producing social or environmental impact as a part of their core operations (Alter, 2007). At the one extreme of the spectrum, there are some of the social entrepreneurs supported by organizations such as Ashoka, the Skoll Foundation or the Schwab Foundation, starting innovative no-profits to achieve social change, and no-profits engaging in revenue-generating activities (e.g., Oxfam). On the other side of the spectrum, there are social enterprises like Belu Water or Divine Chocolate, which are businesses whose aim is to be profitable and financially sustainable, but which are also characterized by shared ownership and/or an entrenched social mission driving all their activities. In-between these typologies there are multiple hybrid forms of organizing, blending their social and business sides in very different ways.

In summary, the definitional debate around social entrepreneurship has its origins in both the academic field and in the practices of organizations describing themselves as members of the social entrepreneurship sector. The analysis of its consequences has thus far focused on its impact on scholarly knowledge of the sector (Alter, 2007; Bacq \& Janssen, 2011; Choi \& Majumdar, 2013; Dacin et al., 2010; Defourny \& Nyssens, 2010) and on the choices available for social entrepreneurs and enterprises on leadership, legal structure, organizational structure and social impact/business model. Considerations on what the definitional debate means for the building of the social entrepreneurship sector appear to be missing (Hoogendoorn et al., 2010). Addressing this gap calls for examining the reactions of multiple stakeholders to the definitional debate and an analysis of how the latter affects the delivery of the support that social entrepreneurs and enterprises need to thrive. This paper will do so by focusing on a specific sector created around social entrepreneurship and by 
presenting evidence concerning the impact of the definitional debate on the practices and players present in it.

\section{RESEARCH METHODS}

A case study design was chosen for this project because it creates the possibility to look at the object of inquiry from the perspectives of multiple actors operating within the same setting and to have an in-depth understanding of how their activities and views are formed (Huberman \& Miles, 2002). The UK was initially chosen as an ideal research setting because, despite having one of the most advanced social entrepreneurship sectors in the world (Defourny \& Nyssens, 2010; Hoogendoorn et al., 2010; Nicholls, 2010; Teasdale, 2012), it is still characterised by a lively debate about the meaning of social entrepreneurship. However, after a first preliminary study, it became apparent that the social entrepreneurship sector was extremely variable and at different stages of development in England, Scotland, Wales and Northern Ireland (Hazenberg, Bajwa-Patel, Roy, Mazzei \& Baglioni, 2016; interviewees of this study; 2015). Each nation has different organizations influencing the sector and operating in it, is subject to different political priorities, and attributes to social entrepreneurship a different meaning (Hazenberg et al., 2016). Furthermore, according to some interviewees and people contacted for the study, while the social entrepreneurship sector has constantly grown in both England and Scotland, it is still in a relatively emerging phase in Wales and Northern Ireland.

Ultimately, England was preferred over Scotland as a case study due to several reasons. First of all, there is more research, and there are more publications - both academic and non-academic - about England than about Scotland. This was expected to facilitate data collection and an in-depth understanding of all the actors and influences at play. Secondly, England's social entrepreneurship sector is extremely inclusive and comprises of members from all the traditional sectors (businesses, government and charities), together with many organizations created on purpose to support its development (e.g., social entrepreneurship-related intermediaries and social investors) (Grenier, 2008; UK government, 2015). This ensures the presence of many institutional players pursuing different goals with regard to the sector's role and conception. Thirdly, thanks to being the seat of the UK government, England is the nation where most government efforts have been put into developing the social entrepreneurship sector (Alcock, 2010; Sepulveda, 2015; Teasdale, 2012). Moreover, it is the country where both American and European conceptions of this phenomenon managed to 
penetrate, probably thanks to its cultural proximity to both (Sepulveda, 2015; Teasdale, 2012), to the presence of international organizations in London (Grenier, 2008) and to some of its universities operating as international conduits of ideas (Benjamin, 2004; Teasdale, 2012; Young, 2004). These characteristics were expected to make England a good "micro-area" to study the confusion around the meaning of social entrepreneurship that is experienced at the global level.

\section{Data collection and analysis}

With the setting established, data collection proceeded in two different phases. In the first one, data was gathered and employed to analyze the development of the social entrepreneurship sector in England, from its appearance (the late 1990s) to 2016. In this phase, archival data was the primary source of information and it consisted of newspaper and magazine articles published in the period 1995-2016, academic papers discussing social entrepreneurship in England and relevant reports produced by the government and national think-tanks. For example, articles were retrieved from social-entrepreneurship-related outlets, such as Third Sector (20002016) or Regeneration and Renewal (2000-2016), national and international media (e.g., The Guardian, The Economist, and The Times), local newspapers or academia-related magazines such as the Stanford Social Innovation Review. The different types of archives were gathered using searches on databases such as Factiva, Nexis UK, Business Source Complete and Google Scholar, using as key-words "social entrepreneur," "social entrepreneurship" and "social enterprise" and restricting the search to documents published in England or discussing England in the period 1995-2016. Additionally, reports and academic papers were retrieved starting from their reference in existing work, either academic or non-academic, or following the suggestions of sector experts that were contacted for this purpose.

This data was analyzed according to a historical method (Barley \& Tolbert, 1997; Zietsma \& Lawrence, 2010), aimed at recreating the state of social entrepreneurship in England at different points in time. Data were grouped according to its publication date and then commonalities and discrepancies were searched for among documents belonging or referring to events in the same time period. Such an analysis led to an in-depth understanding of the historical causes of the current definitional debate and of the overall context in which it arose.

In the second phase, the archival data used to analyze the historical development of social entrepreneurship was complemented with additional archives and 69 interviews with different stakeholders present in the sector. Archival data added for this phase was identified again with the help of 
databases and references, using as key-words the names of influential organizations, which affected the definitional debate throughout time. Among the new documentation retrieved were organizational websites, books, reports and guides on social entrepreneurship produced by sector intermediaries, newspaper articles and academic papers discussing organizations active in England in the social entrepreneurship space, videos and blogs posted online by members and experts of the sector (see Table 1).

Table 1. Archival data breakdown

\begin{tabular}{lll}
\hline Purpose & Type of source & No. \\
\hline History/Phase 1 & Academic papers & 22 \\
& Government and think tank projects & 12 \\
& Newspapers' and magazines' articles & 256 \\
\hline Definitions and & Academic papers & 33 \\
definitional debate/ & Books & 25 \\
Phase 2 & Events videos or video summaries & 41 \\
& Newspapers' and magazines articles & 293 \\
& Sector experts blogs & 392 \\
& Reports and guides on social entrepreneurship & 138 \\
\hline Total & produced in England & \\
\hline
\end{tabular}

The interviews that were conducted, in conjunction with the collection of archival data, were semi-structured and used both to triangulate the information coming from archives and to explore in-depth the four main topics. Questions asked for these purposes revolved around the definition of the terms "social entrepreneurship," "social entrepreneur" and "social enterprise," the prevailing conception of social entrepreneurship in England, the impact of the definitional debate on the sector and the current state of social entrepreneurship in England. Each interview lasted between 25-90 minutes, with most interviews lasting around 45-50 minutes (see Table 2).

Table 2. Interviews breakdown

\begin{tabular}{ll}
\hline Stakeholders & No. \\
\hline Employees of sector intermediaries & 16 \\
Social entrepreneurs/enterprises & 24 \\
Academics & 12 \\
Businesses & 8 \\
Charities & 9 \\
\hline Total & 69 \\
\hline
\end{tabular}

During the second phase of analysis, a first screening was employed to select, within the data available, the parts where information relevant for this 
project was contained, and to divide their content according to the four main topics on which the interviews were focused. Following such screening, the remaining material was analyzed using an inductive approach (Corley \& Gioia, 2004; Glaser \& Strauss, 1967), which allows us to describe a phenomenon according to the words of participants and to explore concepts not covered by the existing literature (Bryman, 2004). All the data available was scrutinized with the support of NVivo Software ${ }^{\mathrm{TM}}$, searching for themes that emerged "as being important for the description of the phenomenon" (Fereday \& MuirCochrane, 2006, p. 3) through multiple iterations. In the first round of coding, data were divided into sentences or paragraphs discussing a specific topic. In the following iterations, patterns were searched for within and across different topics, according to the Gioia method (Corley \& Gioia, 2004), in order to create and refine overall themes containing all the relevant information for the object of study (definitions of social entrepreneurship and their consequences). A small sample of the codes can be found in Table 3 and 4 .

The final list of codes was combined in the two themes of interest for this paper: the typology of definitions of social entrepreneurship and the explanation of the consequences deriving from the definitional debate. The next session will detail the findings in these two categories.

Table 3. Sample of codes on definitions

\begin{tabular}{|l|l|c|c|}
\cline { 2 - 4 } \multicolumn{1}{c|}{} & $\begin{array}{l}\text { 1ST ORDER CONCEPTS } \\
\text { A social enterprise is a business with a } \\
\text { social or ethical purpose. Its object is to } \\
\text { improve the world we live in through } \\
\text { commercial and sustainable means. }\end{array}$ & $\begin{array}{c}\text { AGGREGATE } \\
\text { DIMENSIONS }\end{array}$ \\
\hline \begin{tabular}{l|l} 
So I think social enterprises are \\
predominantly focussed on a social \\
and/or environmental goal rather than \\
a financial goal, however, I do think of \\
course they have a financial mechanism \\
to sustain themselves which is to earn \\
an income through trading, selling \\
goods or services
\end{tabular} & $\begin{array}{c}\text { Sustainable } \\
\text { business }\end{array}$ & \multirow{2}{*}{ BUSINESSES } \\
\hline $\begin{array}{l}\text { Social enterprise is a business that's } \\
\text { trading for a social purpose, where its } \\
\text { primary purpose is the social one. And } \\
\text { it reinvests the majority of its profits in } \\
\text { the pursuit of those social objectives. }\end{array}$ & Trading for \\
purpose & \\
\hline
\end{tabular}

Social Entrepreneurship and Social Enterprise Phenomenon: Antecedents, Processes, Impact across Cultures and Contexts Marzena Starnawska and Agnieszka Brzozowska (Eds.) 


\begin{tabular}{|c|c|c|c|}
\hline 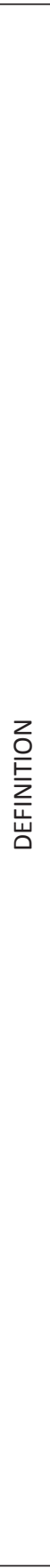 & \begin{tabular}{|l|} 
Technically, social enterprises should \\
be trade-focused, they should operate \\
a triple bottom-line policy, they should \\
have an asset lot where profits might be \\
distributed. \\
I think about it more in terms of taking \\
a more business-like approach to the \\
business of creating social change and \\
trying to create and run models that \\
are... more financially independent. \\
Social entrepreneurship is identifying \\
a problem, a social problem, and \\
choosing to use a business model to fix \\
it, or to start to fix it \\
So I would say the definition is broad \\
for me, it's about a sense of a purpose, \\
which is all about the social impact, \\
but with underlying the strength of a \\
business model, allowing people to \\
make a profit in that kind of context. \\
So for me, a social enterprise is a \\
business with a good cause. It's pretty \\
simple. A social entrepreneur is a \\
person who uses business strategies to \\
achieve social impact. Yeah that's how I \\
define it. It's really simple. \\
Social entrepreneurs are not happy until \\
their ideas have changed the whole \\
society \\
But I think the notion of social \\
entrepreneurship embodies disruption, \\
systems change, making money work, \\
but really looking at really big problems \\
and how do we do this differently \\
So social entrepreneurship is, to me, \\
it's making a change in society when \\
the primary motivator for you is not the \\
financial returns. \\
They've chosen to dedicate their \\
professional lives and much of their \\
personal energy, to solving problems \\
that they have first-hand experience of \\
I think it's just about saying that \\
thinking about new ways of going \\
about business, regardless whether its \\
for-profit or not-for-profit, that makes \\
social change and social impact kind of \\
possible
\end{tabular} & $\begin{array}{l}\text { Business model to } \\
\text { solve social causes }\end{array}$ & BUSINESSES \\
\hline
\end{tabular}




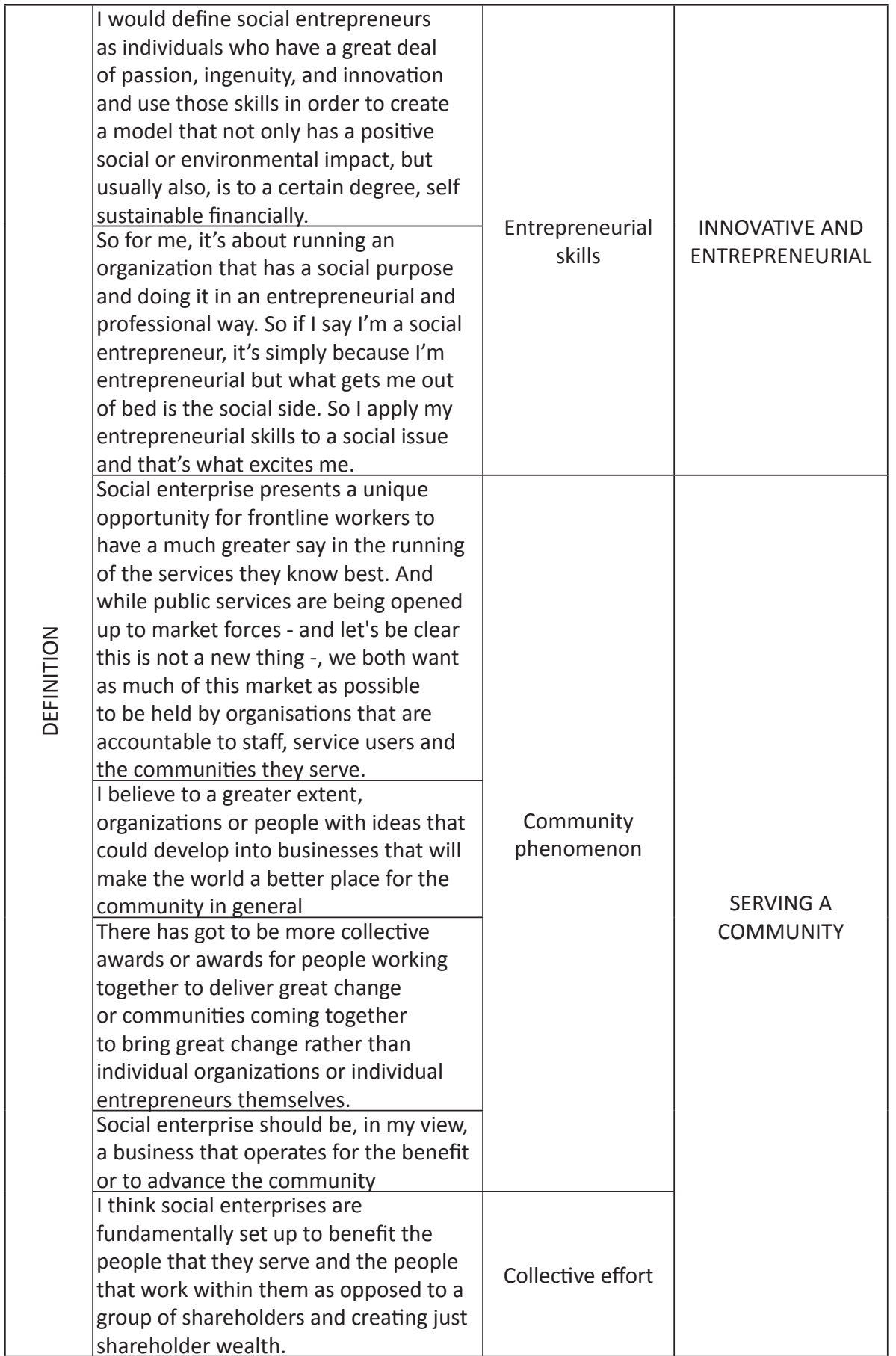


Table 4. Sample of codes on consequences

\begin{tabular}{|c|c|c|c|}
\hline & 1ST ORDER CONCEPTS & \begin{tabular}{|c|} 
2ND ORDER \\
THEMES
\end{tabular} & \begin{tabular}{|c|} 
AGGREGATE \\
DIMENSIONS \\
\end{tabular} \\
\hline \multirow[t]{2}{*}{ 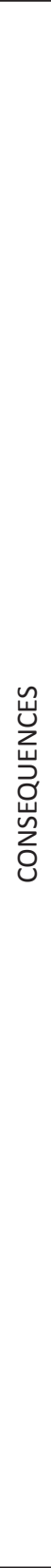 } & $\begin{array}{l}\text { Lots of bright people all coming in it with different } \\
\text { definitions of the same thing isn't helping the sector } \\
\text { right now. It's almost like the sector needs to get } \\
\text { together to make some decisions collaboratively and } \\
\text { announce its intentions publicly } \\
\text { I do think they hamper the sector. I think they prevent } \\
\text { any cross-learning, any cross-collaboration because } \\
\text { they are different animals } \\
\text { It's a very practical problem because of access to } \\
\text { funding. And it's difficult to see how you can resolve } \\
\text { the problem, but it does mean there's an awful lof the } \\
\text { standard funding routes aren't terribly available to } \\
\text { social enterprises } \\
\text { See, the problem is, when the funding stream was } \\
\text { changed back in 2009, 2010 whenever it was, to } \\
\text { support social enterprise activity, all organizations } \\
\text { that relied on funding and grant suddenly changed } \\
\text { the name of their from Fred Blogs whatever to Fred } \\
\text { Blogs Social Enterprise. So you've got hundreds if not } \\
\text { thousands of organizations that are desperately just } \\
\text { spending probably } 80 \% \text { of their week trying to attract } \\
\text { funding which only leaves } 20 \% \text { of their week to do } \\
\text { anything social } \\
\text { All these different definitions just confuse people } \\
\text { I think the problem is, in the public mind, when you } \\
\text { say to them what is a social enterprise, sometimes it } \\
\text { is a little bit fuzzy } \\
\text { If we can achieve a rigorous definition, then those } \\
\text { who support social entrepreneurship can focus their } \\
\text { resources on building and strengthening a concrete and } \\
\text { identifiable field. Absent that discipline, proponents } \\
\text { of social entrepreneurship run the risk of giving the } \\
\text { skeptics an ever-expanding target to shoot at }\end{array}$ & $\begin{array}{l}\text { Confusion } \\
\text { for the } \\
\text { public }\end{array}$ & PROBLEM \\
\hline & $\begin{array}{l}\text { I think anyone who actually wants to get involved or } \\
\text { back schemes, decides what they are interested in } \\
\text { and support that.... The nice thing is that probably } \\
\text { both sides get some attention and actually that gets } \\
\text { people thinking what they think, which might be a } \\
\text { good way to progress } \\
\text { I think we're very focused on having quite clear } \\
\text { boundaries of we think is involving but within that } \\
\text { having a pretty broad territory that covers a lot of } \\
\text { ground and that's important too because we want to } \\
\text { be inclusive and encouraging because that's what the } \\
\text { sector is about }\end{array}$ & Inclusiveness & STRENGTH \\
\hline
\end{tabular}




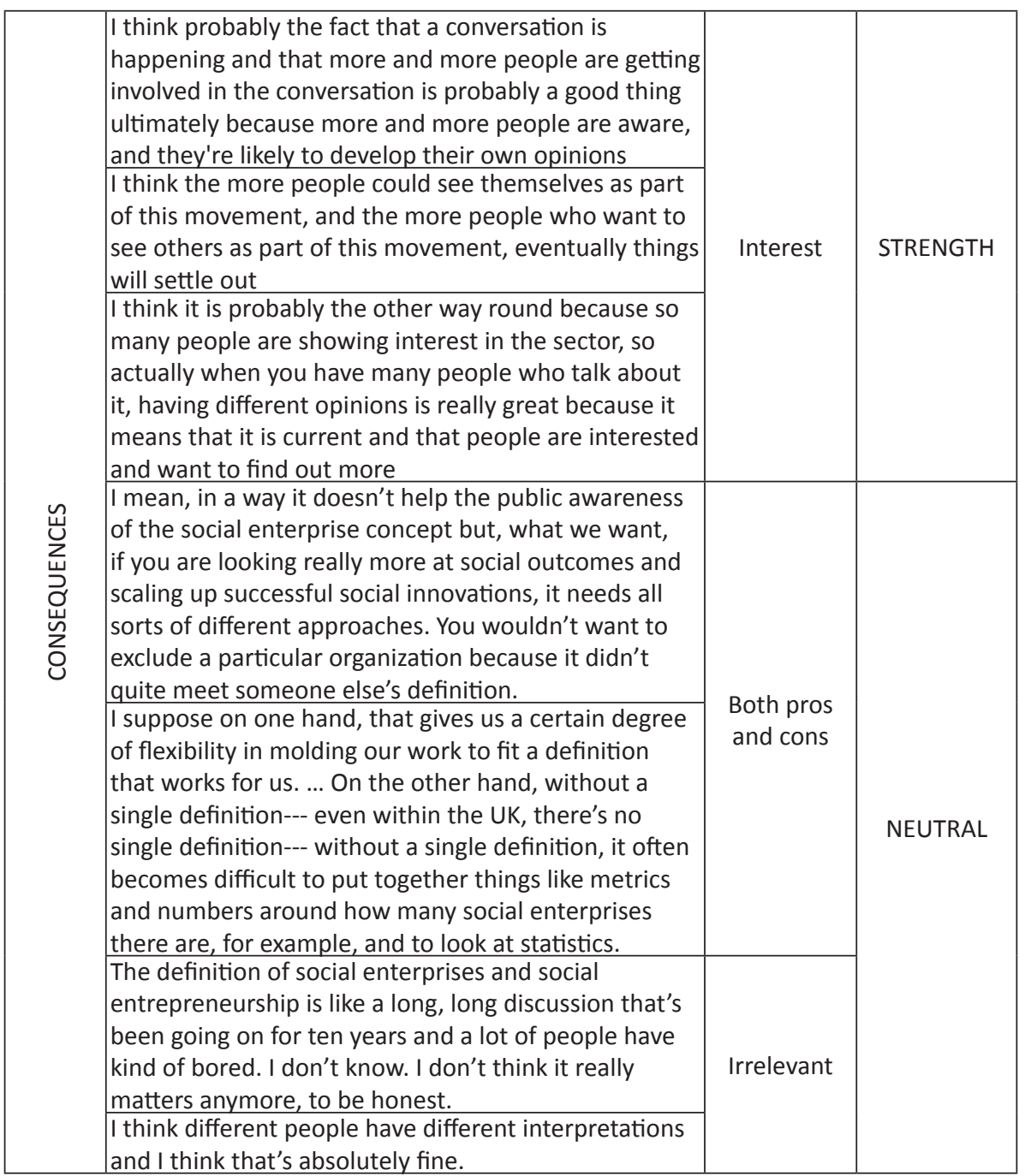

\section{FINDINGS}

\section{Three schools of thought in practice}

Multiple sources of archival data presented evidence of a definitional debate developing within the social entrepreneurship sector in England throughout the last 15-20 years (Ainsworth, 2008; Barrett, 2008; Brown, 2008; Harding, 2004; McCurry, 2005; Plummer, 2005; Seanor \& Meaton, 2007; Simms, 2008). In those documents, in the ones produced by sector stakeholders and in the interviews conducted for this study, it was possible to discern three 
macro-conceptions of social entrepreneurship. The first one refers to social enterprises as businesses, the second one focuses on social entrepreneurs as innovators and the third one considers social entrepreneurship (social entrepreneurs, social enterprises and social entrepreneurial projects) as a community-related phenomenon.

Manager of social enterprise 1: "I mean previous to this, I've been in the social enterprise sector pretty much since the social enterprise term was coined, in fact, I have. And it took me probably seven years to realize that when the School for Social Entrepreneurs was talking about social entrepreneurs, they weren't talking about social enterprise. They were talking about three different types of business model: one is a completely unsustainable business that gets grants, number two is a social enterprise which should be generating its own income, but has a social mission, and then the third one is about an individual entrepreneur who's set up to do basically the same as any other business but happens to be doing something social."

These three macro-conceptions sometimes have an overlap, but more often than not they diverge on the core characteristics they attribute to social entrepreneurship. As a consequence, they have often created open tensions between their proponents. An example of this is the case of UnLtd, whose founding members gradually left it due to disagreement among themselves and with the foundation's CEO, regarding whom to support as social entrepreneur or enterprise with the funds available (Burne James, 2014; Grenier, 2008; interview of UnLtd founder, 2015).

The first macro-conception of social entrepreneurship revolves around social enterprises, described as businesses trading for a social purpose (examples of definitions in Table 3).

Social Enterprise UK website: "Social enterprises are businesses trading for social and environmental purposes. Rather than maximizing private profit, their main aim is to generate profit to further their social and environmental goals."

It is a view supported by the government, by influential sector intermediaries like Social Enterprise UK, the Social Enterprise Mark and Co-ops UK and by the most renowned social enterprises based in England, such as the Big Issue, Divine Chocolate, Belu Water, Hackney Community Transport Group (HCT) or Greenwich Leisure Limited (GLL). Thanks to the support of these visible and powerful players, this conception appeared from the archival data as the most popular one in the public discourse around 
social entrepreneurship in England at present. This was well reflected in the frequency with which it came up in the interviews conducted.

However, possibly because of its success and of the presence among its proponents of organizations owing their survival to the vagueness of the concept (Huckfield, 2014), it is also the conception of social entrepreneurship for which there is a strong internal debate.

Liverpool Post, 7th June 2012: "Of course, at Social Enterprise Network we have a very clear idea of what defines social enterprise and we are working very hard to challenge misconceptions and misrepresentation of the term. ... Debate will naturally remain...but perhaps JM Keynes got it right when he said: "It is better to be vaguely right than precisely wrong."

For example, some people and organizations argue that social enterprises - being businesses - should be financially sustainable and reinvest the majority of their profits to create social impact. Others believe that the core trait of social entrepreneurial business is its shared ownership and not the creation and/or reinvestment of profits. Also, the exact level of revenues that a social enterprise should derive from trade has been open to debate. For example, the Social Enterprise Mark requires organizations to obtain at least $50 \%$ of their revenues from trade to certify them as social enterprises, whereas for the government the threshold is set at $25 \%$ and for Social Enterprise UK a specific threshold around $50 \%$ would be desirable but not needed (Ainsworth, 2010; Cabinet Office, 2012; Findlay, 2013; Jolly, 2012; Ridley-Duff \& Southcombe, 2012; Social Enterprise Mark, 2009; Social Enterprise UK, 2013; Third Sector Magazine, 2013). Other examples of slight variations of the conception of social enterprises as businesses can be found in the quotes below.

Director Magazine, February 2004: "Where social enterprises differ from the traditional model of charity is in tackling the underlying causes of social problems as well as the effects."

Third Sector Magazine, 30th July 2008: "The first model describes enterprises that trade purely to make a financial return but use profits for a social purpose. ... Model two covers enterprises whose trading activity has a social impact, but where a balance is struck between increasing social impact and maintaining a financial return. ... The third model describes businesses whose financial return increases in parallel with their social return. Examples would be farmers markets and wind farms." 
Manager of social enterprise 2: "Social enterprises are asset-locked businesses trading for a social purpose. Sustainable businesses reinvesting their profits into furthering their social mission. Business solutions to social problems. Social entrepreneurs are capitalizing on market failure or business solutions to create social equality."

The second macro-conception focuses instead on social entrepreneurs. It depicts them as innovators and disruptors changing the status quo of multiple sectors to create a fair and equal society (examples of definitions in Table 3). The leading proponents of this view are international organizations like Ashoka, the Schwab Foundation and the Skoll Foundation, some scholars, and multinational corporations such as Unilever.

Ashoka's webpage: "Social entrepreneurs are individuals with innovative solutions to society's most pressing social problems. They are ambitious and persistent, tackling major social issues and offering new ideas for wide-scale change."

Social entrepreneur 1: "So social entrepreneurship is, to me, it's making a change in society when the primary motivator for you is not the financial returns. It's seeing the society change and improve."

Because of its international origins, this macro-conception of social entrepreneurship is not shared by many local and national sector members. Nonetheless, it obtains a significant resonance thanks to the sustained publishing activity of some of its supporters, such as Ashoka or the Skoll Centre (Drayton, 2006; Elkington \& Hartigan, 2008), and to an agreement among its proponents that is stronger than that among those of the other two macroconceptions. Indeed, only in two cases was it possible to observe among the archival documents a slight variation of this macro-conception, due to the inclusion of references to trade and business models in its definition (Garet, 2014; Villa, 2016), and in no case were there traces of a strong internal debate within the supporters of this view.

Finally, the third macro-conception describes social entrepreneurship as the realization of initiatives - either business-like or charity-like - that benefit the community where they are implemented (examples of quotes in Table 3). This view is supported by intermediaries such as the School for Social Entrepreneurs and UnLtd and by some charities such as the Young Foundation, and it was the most prominent conception of social entrepreneurship at the origins of the sector (Grenier, 2008; Huckfield, 2014; Leadbeater, 1997; Teasdale, 2012). 
The causes for its gradual marginalization within the public discourse might be found in the shift of the government's and main funders' priorities from community revitalization to financial sustainability, and in the excessive vagueness of its definition. Indeed, social entrepreneurs included in this view are individuals setting up a social enterprise, any worker/employee/ volunteer participating in the social economy, innovative public servants and society's change-makers (Downer, 2006; Jones \& Keogh, 2006). Similarly, social enterprises that match its focus are cooperatives, social enterprises reinvesting profits and doing projects in their local area, and no-profits creating new employment or inclusion opportunities for marginalized groups (Brodie, 2010; Burne James, 2014; Reid \& Griffith, 2006; Ridley-Duff \& Southcombe, 2012).

Third Sector, 15th June 2010: "Guinness is launching a social entrepreneurship programme in the UK with social enterprise charity UnLtd and young people's charity Rathbone ... for people who develop urban regeneration concepts that will make a positive difference to their local communities."

Manager of social enterprise 3: "I think social enterprises are fundamentally set up to benefit the people that they serve and the people that work within them as opposed to a group of shareholders and creating just shareholder wealth. It is about taking the perspective of the community versus the perspective of only patients' care."

Altogether, the three macro-conceptions of social entrepreneurship have created a definitional debate. Some of the sector members coming from the charity world have disagreed vehemently with the risk-taking attitude implicit in the conception of social entrepreneurs as innovators and disruptors (Cater, 2006; Little \& Warrell, 2007; Palmer, 2006). Individuals and organizations connected to the cooperative tradition have instead worried about the focus of the same macro-view on "hero-preneurs," discounting the collective effort required for social change and the history of social entrepreneurship as a phenomenon meant to foster social inclusion (Dey \& Teasdale, 2016). On the other hand, proponents of the "social entrepreneurs as innovators" view have often criticised the focus on "social enterprises as businesses" or on "social entrepreneurs as community-regenerators" because these types of actors lack novelty and the ambition of changing the root causes of the problems they are tackling (Caulkin, 2006). 
Academic 1: "You know, the biggest threat for me is that the social enterprise sector becomes a quasi-government sub-contracting group that are delivering goods and services but that are not changing the actual problem and for me the key of entrepreneurship is ... about really promoting system change."

Social entrepreneur 2: "There is a huge emphasis on the sort of the personality cult and I think that, actually, isn't always that helpful. ... actually, you know, the world is made by lots of people who apply their time and energy, skills and not just the few in the limelight who happen to be the people who set up things and managed to take them forward."

The definitional debate has been a constant feature of the sector and, as such, can be expected to have shaped its development. The next section will explore if and how this was the case, by looking at what sector members consider to be the current characteristics of the sector that can be attributed to the definitional debate.

\section{The consequences of the definitional debate}

While almost everyone agrees on the presence of a definitional debate around the concept of social entrepreneurship, there are very different opinions on what this means for the sector. According to some people and organizations, the lack of a single definition is a problem, for others it is an opportunity. Finally, a third group sees the definitional debate as something of interest only for academics. In general, those that were more critical about the definitional debate were the managers of social enterprises and the sector intermediaries connected to either the first or the third macro-conception. On the contrary, businesses and scholars were generally discounting the definitional debate as something belonging to the past. Interestingly, most of the views in support of the definitional debate came from the proponents of the second macro-view. This might be explained by the fact that, being part of a sub-sector which is much more homogeneous in its interpretation of social entrepreneurship, they are less subject to the contradictions and issues that might arise out of the lack of a clear definition.

Sector members seeing the definitional debate as negative justify their critiques with five core points. Firstly, the lack of a single definition hampers the effective provision of funds to social entrepreneurs and enterprises. Secondly, it makes it impossible for the government to grant the sector statutory rights and tax advantages. Thirdly, it hampers the growth of public awareness about the uniqueness and value of this new sector. Fourthly, it 
does not allow all sector stakeholders to push together for the growth and development of the sector. Finally, it reduces the probability of doing an accurate mapping of the social entrepreneurial activity present in the country. These problems have been characterizing the sector since its inception and are still felt nowadays and some sector members believe that the definitional debate played a role in this sense.

As far as funding is concerned, the lack of a univocal definition of social enterprises and entrepreneurs contributes to the disconnection between the social entrepreneurship sector and the social investment one (Cabinet Office, 2012; Nicholls, 2006; Pharoah, 2012; Schwartz, 2012; Temple, 2014; Third Sector Magazine, 2015; Villa, 2016). Funders are often unable to distinguish social enterprises from traditional businesses or charities and, therefore, are less willing to invest in them (Baines, Bull \& Woolrych, 2010; Chapman, Forbes \& Brown, 2007; Jones \& Keogh, 2006). At the same time, the lack of clarity around the concept opens up the possibility for any organization or individual to label herself as "social enterprise" or "social entrepreneur" and thus to access special funds, investments and grants that were created to support the sector (Simms, 2008).

Employee of sector intermediary 1: "(The lack of a clear definition) is a very practical problem because of access to funding. ...it does mean there's an awful lot of the standard funding routes that aren't terribly available to social enterprises. And some of the issues that relate to that ...like including social enterprises in supply chains and allowing social enterprises to bid for government funding contracts, don't work terribly well because for a lot of the social enterprises."

Third Sector, 4th June 2013: "The purists tend to see social investment as something that should be dedicated to encouraging a particular type of highly social organization. There is not yet a uniform view on exactly what type of organization ought to be supported, but purists...believe businesses that are not so purely focused ought to receive less or no support, because they are not really social enterprises."

Legislation-wise, the lack of a definition prevents the creation of tax breaks and statutory rights because the government cannot isolate and establish who will benefit from them. Additionally, it reduces the impact of policy reforms like the Social Value Act - an act meant to favor the entrance of third-sector organizations in the supply chains of the public sector. In fact, 
public bodies and local authorities cannot easily distinguish social enterprises from other types of organizations that bid for public contracts.

Academic 2: "The lack of clarity has meant that there haven't been tax benefits, or tax breaks or funding programs because they can't decide who would get it and who wouldn't."

Third Sector, 1st October 2013: "O'Donohoe also called for a clear definition of social enterprise 'We're asking big businesses and government bodies to involve social enterprises in their supply chains, ' he said. "We can't ask them to do a social audit every time."

The presence of multiple definitions of social entrepreneurship also contributes to the persistent low awareness among the general public about the sector and its specificities (Chapman et al., 2007; Donovan, 2009; Grewal, 2008; Morrison, 2013; Muñoz, 2009; Richardson, 2016). Indeed, the lack of a definition makes it difficult to explain to people what exactly is distinctive about social entrepreneurs and enterprises. In turn, this can mean that social enterprises and entrepreneurs often risk spending more time proving to funders and customers their value rather than actually producing social impact.

Employee of sector intermediary 2: "(Approaching corporate partners) is a challenge, for sure. For sure, it is a challenge and it always does take a little bit of explaining and even then, it's often really when they meet a social entrepreneur, that ... they're like: I get it. I get what you mean."

Third Sector magazine, 13th October 2009: "The standard of knowledge among ordinary people who don't work in the sector is very low, 'she says. 'Social enterprise just isn't in the public domain. It's not an easy concept for many people to grasp, especially that it's not 'not-for-profit' but 'not-forpersonal-profit'.' Many people, she says, think of social enterprise as a public sector activity."

Independent.co.uk, 14th July 2013: "There's clearly an appetite in the market for social enterprise products; people look at what we do and their faces light up," she said. "But when we say it's a social enterprise, they don't really understand it. We talk [instead] about balancing business and social needs. They are both equally important." 
Fourthly, according to some interviews (but not to archival data, where this view could not be traced) the lack of a definition does not allow the sector to push as a whole for the obtainment of more resources and attention, generating instead an increasing numbers of buzzwords. This might end up lowering its legitimacy with external stakeholders, such as the national and local authorities or corporates and businesses.

Employee of sector intermediary 3: "I think the onus is on the sector itself to demonstrate a united front, to be clear on these things and not to have internal debates that detract from the issues because actually most people's definitions have a lot more in common than they do differences. But it is a risk. I think at the moment, it's not a damaging one but ...if it starts to become fragmented, you lose the power of the whole and that's a risk as well." Manager of social enterprise 4: "I think it's important to clearly define what a social enterprise is because if it becomes fuzzy or becomes nebulous, then it affects policy and opinion-making - for example we work with the local enterprise partnership and if we all start falling out about the definitions, what it is and what it's not, they won't take us seriously."

Finally, some of the interviewees were worried about the definitional debate because it hampers their attempts to map the presence of social enterprises country-wise or in specific local areas. This can mean missed opportunities for interested people and organizations to get in touch with social entrepreneurs and enterprises and for the latter to know where supporters and resources are located. Additionally, this prevents the production of sound statistics about the actual growth of the sector.

According to many interviewees and to some archival data, however, maintaining multiple definition of social entrepreneurship is mostly beneficial (Dearden-Phillips, 2011; Ridley-Duff \& Southcombe, 2012; Schwartz, 2013). First of all, it makes the sector inclusive and, consequently, favors its growth and hype. The more people and organizations consider themselves as involved in the sector, the more "word of mouth" is generated about it.

Member of charity 1: "I think probably the fact that a conversation is happening and that more and more people are getting involved in the conversation is probably a good thing ultimately because more and more people are aware, and they're likely to develop their own opinions."

Employee of sector intermediary 4: "I think it is really good that the debate continues because I think the debate is the next generation learning about 
these issues and textures and so I think it is really healthy that that debate is vibrant, I am not the slightest a bit bored about it."

Secondly, by keeping sector boundaries as broad as possible opens up opportunities for organizations with very different conceptions of social entrepreneurship to get involved in it, and to find their own niche. This, in turn, is positive because it facilitates the attraction of new players and it ensures that different types of social entrepreneurial activities can find the support they need.

Social entrepreneur 3: "I think anyone who actually wants to get involved or back schemes, decides what they are interested in and support that...The nice thing is that probably both sides get some attention and actually that gets people thinking what they think, which might be a good way to progress."

Social entrepreneur 4: "I think you do have to support individuals ...but, you know, there is only so much support that anybody could individually give me, before I actually need the way Liverpool and Manchester councils operate to begin to change also."

Finally, some interviewees felt that the sector is still young and thus it is normal for it to have unclear boundaries and definitions. Its openness creates room for innovation and for making people feel part of a big community.

Member of charity 2: "It's creating a bit of a community that people can feel a part of.... remember making a presentation and people came up from the audience afterwards and said, "Thank you for giving me a label for what I am. I know that I can make money and I know that I can do good and I didn't know that there were other people who thought this way"

Besides people and organizations feeling strongly negative or positive about the definitional debate, there are also some sector members who are neutral about it. Their main argument is that in general there is a broad agreement, so small differences don't matter and merely serve to create distractions. Rather, what matters is to support people and organizations, who are trying to create a better world and make a positive change.

Social entrepreneur 5: "I think it's a distraction from what really matters. People should be---organizations should be judged by their impact, not about whether they're profit-making or not. Organizations should be judged by how effectively they're run and by the company culture that they're able to create. 
... Those are the things that we should be talking about and shining light on good examples. I think this whole hype around social enterprises has created a lot of distraction, has created a lot of new buzz words, it has created sort of new sectors around -it's something that really nobody is quite sure how to define and that really has always existed."

In some cases, the interviewees holding this opinion recognized the existence of both benefits and issues generated by the definitional debate but believed that, overall, their trade-off and leveling out of each other made the whole disquisition irrelevant.

Business 1: "It's a difficult question. I think the debate about defining what a social enterprise is, has become pretty stale, and it's not something that people are really talking about anymore. ...l think in the end, no one is probably going to agree on one single definition of it. I suppose on one hand that gives us a certain degree of flexibility in moulding our work to fit a definition that works for us. ... On the other hand, without a single definition--- even within the UK, there's no single definition--- without a single definition, it often becomes difficult to put together things like metrics and numbers around how many social enterprises there are, for example, and to look at statistics."

In some other cases, interviewees felt that the sector was so inclusive at this point and its boundaries so ill-defined that the chance to reach an agreement is lost forever and should, therefore, be excluded from the public discourse in favor of topics for which something could still be done.

Social entrepreneur 5: "I don't know. The definition of social enterprises and social entrepreneurship is like a long, long discussion that's been going on for ten years and a lot of people have kind of bored. I don't know. I don't think it really matters anymore, to be honest. ... I just think it's worthless because nobody really understands what it means and because it's become so wide, it doesn't really mean anything anymore.

In conclusion, the data showed the presence of three different conceptions of social entrepreneurship within the sector in England. Most of the archival data consulted and the interviews conducted showed a widespread awareness among sector members of their different conceptions of the sector, of its role and of its boundaries. However, whilst most people agreed on the lack of a single definition, it was hard to understand what its consequences are. In 
fact, views on the matter varied from positive, to negative, to neutral. The next section discusses how these findings relate to the existing literature.

\section{DISCUSSION}

The three views of social entrepreneurship that could be traced in the data partially match those of the three schools of thought identified by the existing literature. The "social entrepreneurs as innovators" view is closely related to the school of thought referred to by Defourny and Nyssens (2010) as "The Social Innovation School of Thought" (p. 41) and to the academic discourse that Mair and Marti (2006) described as focused on the catalysts for social transformation. The "social enterprises as businesses" view is instead connected to the "EMES approach to social enterprise" (Defourny \& Nyssens, 2010, p.42) and, to a certain extent, to the scholarship looking at social practices of businesses (Mair \& Martí, 2006). Finally, the view of "social entrepreneurship as community initiatives" can be seen as implicitly encompassing the definitions of social entrepreneurship as a collective activity, solving failures of either the public or private sectors (Bacq \& Janssen, 2011). Additionally, both the business-related and the communityrelated views sometimes include the "Earned Income" school of thought (Defourny \& Nyssens, 2010, p.40; Sepulveda, 2015), by accepting within their realm charities interested in becoming financially self-sustainable or no-profits engaging in revenue-generating activities for the benefit of their communities.

The data collected for this study also confirms the findings of Nicholls (2010) and Teasdale (2012) regarding the presence in the sector of paradigm-building actors fighting for legitimacy in the space and proposing diverging views of social entrepreneurship and social enterprises. Several interviewees, when commenting on the definitional debate, mentioned sector intermediaries, financial intermediaries and umbrella bodies as one of the causes of the presence of multiple definitions of social entrepreneurship. They believed that the insistence of certain players on different nuances of the definition, in order to support their own work in the sector, made it difficult to reach an official definition even if a broad agreement was already in place. Finally, some of the considerations about the negative consequences of the lack of a clear definition, such as the opportunity for any organization to label itself as a social enterprise, supported the findings of Dey and Teasdale (2016) on organizations sometimes only pretending to be social enterprises in order to obtain resources. 
However, there are also differences between the academic debate on social entrepreneurship and the one happening in the sector in England. On the one hand, the scholarly discourse rarely focuses explicitly on social entrepreneurship as a community-related activity. This might suggest that such a definition is probably typical of the sector in England and might not be sufficiently represented in other contexts. On the other hand, the conception of "social entrepreneurship as engagement of no-profits in revenuegenerating activities", often cited by the literature (Bacq \& Janssen, 2011; Defourny \& Nyssens, 2010; Hoogendoorn et al., 2010; Mair \& Martí, 2006), was not really traceable in the data, if not within a few quotes that could be connected to either the business- or community-related macro-conceptions..

This finding conflicts with those of Teasdale (2012), which presented the "Earned income" school of thought as the one towards which the sector in England had been heading since 2006. Furthermore, while Teasdale (2012) placed cooperatives as a stand-alone conceptualization of social enterprise present in England, according to the data gathered for this study, cooperatives are often included in the "social enterprise as business" discourse or in the "social entrepreneurship as community-related phenomenon" and only appeared as a stand-alone category in some historical archives. These incongruences might be explained by the different sample and sector boundaries used by the two studies (social enterprises and paradigm-builders conceptions for Teasdale (2012) vs. social entrepreneurship and generalstakeholders conceptions for this paper), or by a further change of the public discourse since 2010, the year in which Teasdale's data collection stopped.

The evolution of the definitional debate and of the public discourse observed in the archival data also suggests a trend that the existing literature on the sector still has not addressed: the increasing shift of the sector in England towards the entrepreneurial and business side of social entrepreneurship, with no-profits and community-related initiatives being gradually left out of the public discourse. This trend can be attributed to a mix of changes at the macro-level - such as the economic crisis - and at the policy level - such as the institution of the social investment sector and the encouragement of self-sustainable social enterprises able to deliver public services (Dey \& Teasdale, 2016; Hazenberg et al., 2016; Nicholls \& Teasdale, 2016; Sepulveda, 2015; Teasdale, 2012). As such, it confirms the model elaborated by Kerlin (2013), which included the type of government and its political orientation, and macro-factors such as economic development, in the institutional conditions shaping the evolution of social entrepreneurship in different countries.

The core contribution of this paper, however, comes from the findings on the consequences of the presence of a definitional debate in the social 
entrepreneurship sector. Thus far, the lack of clarity around the meaning of social entrepreneurship has prevalently been portrayed as a negative issue. From an academic point of view, the impossibility to define a concept, hampers the creation of a dedicated scholarly field, neatly separated from existing ones such as entrepreneurship and the development of a clear research agenda (Austin, 2006; Lehner \& Kansikas, 2013; Mair \& Martí, 2006; Nicholls, 2010). On the contrary, for the stakeholders involved in the social entrepreneurship sector, the lack of a univocal definition of the phenomenon is not perceived as necessarily a problem. The findings showed that in England, members of the sector consider the lack of a definition sometimes as an issue, sometimes as an opportunity, and sometimes as something that does not matter.

The reasons why the definitional debate might be an issue complement and partially disconfirm the hypotheses of Peredo and McLean (2006). The two authors mentioned three potential, practical downsides of the lack of a definition: the absence of sector-specific performance metrics and evaluation standards; the missed opportunity of creating legislative support; and the difficulty in attracting talent. The findings of this paper confirmed that the legislative support for the sector could be hampered by the lack of a definition. However, neither interviews nor archival data mentioned the sourcing of talent as a problem and even if the absence of performance metrics often appeared in the archival data as an issue, it was never connected as such to the definitional debate. At the same time, the findings highlighted a new set of issues that can arise due to the multiplicity of definitions of social entrepreneurship. These issues range from the obtainment of appropriate financial and non-financial support for social entrepreneurs and enterprises, to the difficulties in mapping the sector and in raising awareness of it among the general public or in lobbying for it with a single voice.

\section{CONCLUSION}

The paper set out to enquire what the consequences of a lack of definition of social entrepreneurship are for sector members and stakeholders. To do so, it looked at data from the social entrepreneurship sector in England, where the presence of a definitional debate is well known. The findings show that the meanings attributed by sector members to the concepts of "social entrepreneurs" and "social enterprises" - at least in England - are slightly different from those presented by the academic literature. This might suggest that the practicing of social entrepreneurial activities and the involvement in the sector of multiple paradigm-building players are changing the focus of 
this emerging sector over time, or that the scholar view of the sector is not fully aligned with its actual development.

The findings also show that the lack of a single conception of social entrepreneurship has negative consequences, not only for the study of this discipline, as extensively discussed by the literature, but because it can also cause issues for practitioners. However, this might not be necessarily the case. Some sector members, indeed, consider the definitional debate as a strength of the sector, and not just as a liability. Accepting multiple views makes the sector inclusive, open to innovation, and supportive of a wide variety of projects that aim to benefit society at large. The fact that the sector has kept on growing in England over the past 20 years might mean that these benefits actually overcome, or at least match, the negative consequences of the definitional debate. As such, the latter might also be seen as irrelevant for the sector and its stakeholders

The study presents some limitations. Firstly, it is based on a single case study; consequently, its findings cannot be generalized and may be specific to the sector analyzed. Secondly, it relies on interviews and archives, which risk offering only a partial view of what happens in the sector and which have intrinsic biases, for example, their production based on a specific goal or input. Finally, the relatively limited number of interviews makes it hard to establish how widespread and detrimental the issues and benefits of the definitional debate emerging from the findings are.

Nonetheless, the presence of these limitations, together with the novelty of some of the findings, also opens up several avenues for future research. The only partial alignment between the schools of thought on social entrepreneurship described in the academic literature and those that emerged from the data on the English social entrepreneurship sector, calls for more empirical studies on how the terms "social entrepreneurship", "social enterprises" and "social entrepreneurs" are used in practice. Additionally, it calls for a revision and update of the academic discourse on social entrepreneurship.

Furthermore, it would be essential to explore further the state of the sector in England with a quantitative study, verifying the findings of this paper with a bigger sample of stakeholders. Finally, it would be interesting to analyze in greater depth, maybe with the use of a comparative study, the nature of institutional conditions and organizational strategies that give rise, and persistence, to the definitional debate around social entrepreneurship. 


\section{References}

Achleitner, A.-K., Spiess-Knafl, W., Lutz, E., \& Mayer, J. (2012). Disentangling gut feeling: Assessing the integrity of social entrepreneurs. VOLUNTAS: International Journal of Voluntary and Nonprofit Organizations, 24(1), 93-124.

Ainsworth, D. (2008, December 10). Social enterprise hallmark goes national. Third Sector, p. 11.

Ainsworth, D. (2010, May 18). Steady rise for enterprise mark. Third Sector, p. 2. Alcock, P. (2010). Building the Big Society : A new policy environment for the third sector in England. The Policy Press, 1(3), 379-389.

Alter, K. (2007). Social Enterprise Typology. Washington, DC.: Virtue Ventures LLC. Ashoka UK. (2015). Ashoka in the UK 2015. Retrievied from https://www. ashoka.org/en/country/united-kingdom-0

Austin, J.E. (2006). Three Avenues for social entrepreneurship research. In J. Mair, J. Robinson \& K. Hockerts (Eds.), Social Entrepreneurship (pp. 2233), Basingstoke: Palgrave Macmillan.

Austin, J.E., Stevenson, H., \& Wei-Skillern, J. (2006). Social and commercial entrepreneurship: Same, different, or both? Entrepreneurship Theory and Practice, 30(1), 1-22.

Bacq, S., \& Janssen, F. (2011). The multiple faces of social entrepreneurship: A review of definitional issues based on geographical and thematic criteria. Entrepreneurship \& Regional Development, 23(5-6), 373-403.

Baines, S., Bull, M., \& Woolrych, R. (2010). A more entrepreneurial mindset? Engaging third sector suppliers to the NHS. Social Enterprise Journal, 6(1), 49-58.

Barley, S.R., \& Tolbert, P.S. (1997). Institutionalization and structuration: Studying the links between action and institution. Organization Studies, 18(1), 93-117.

Barrett, H. (2008, July 30). Enterprise special: Three that thrive. Third Sector, p. 18.

Benjamin, A. (2004, October 9). Skoll backs social business school. The Guardian Special Supplement, p. 17.

Borzaga, C., \& Defourny, J. (Eds.). (2001). The Emergence of Social Enterprise. London: Routledge.

Brodie, D. (2010, December 15). Talks over role of social enterprise. East Anglian Daily Times, p. BIZZ.

Brown, J. (2008, August). Letter of the month. Director, 27.

Bryman, A. (2004). Social Research Methods ( $2^{\text {nd }}$ ed.) Oxford: Oxford University Press.

Burne James, S. (2014, October 24). Two social enterprises refuse further funds from UnLtd over "erosion of not-for-private-profit principles." Third Sector.

Cabinet Office. (2012). Social Enterprise: Market Trends. London.

Cater, N. (2006, November 15). Skollarship, or how to forget your scruples. Third Sector. 
Caulkin, S. (2006, February 12). How the not-for-profit sector became big business. The Observer, p. 8.

Chapman, T., Forbes, D., \& Brown, J. (2007). "They have God on their side": The impact of public sector attitudes on the development of social enterprise. Social Enterprise Journal, 3(1), 78-89.

Choi, N., \& Majumdar, S. (2013). Journal of Business Venturing Social entrepreneurship as an essentially contested concept: Opening a new avenue for systematic future research. Journal of Business Venturing, 29(3), 1-14.

Corley, K.G., \& Gioia, D.A. (2004). Identity, ambiguity and change in the wake of a corporate spin-off. Administrative Science Quarterly, 49(2), 173-208.

Corner, P.D., \& Ho, M. (2010). How Opportunities develop in social entrepreneurship. Entrepreneurship Theory and Practice, 34(4), 635-659.

Dacin, P.A., Dacin, M.T., \& Matear, M. (2010). Social entrepreneurship : Why we don' $\mathrm{t}$ need a new theory and how we move forward from here. Academy of Management Perspectives, 24(3), 37-58.

Dearden-Phillips, C. (2011). Losing my religion? The theology of social enterprise. Retrieved March 15, 2017, from http://nakedentrepreneur. blogspot.it/2011/01/losing-my-religion-theology-of-social.html

Dees, J.G., \& Anderson, B.B. (2006). Framing a theory of social entrepreneurship: Building on two schools of practice and thought. In Research on Social Entrepreneurship: Understanding and Contributing to an Emerging Field (pp. 39-66). Retrievied from https://centers.fuqua. duke.edu/case/wp-content/uploads/sites/7/2015/02/BookChapter_ Dees_FramingTheoryofSE_2006.pdf

Defourny, J., \& Nyssens, M. (2010). Conceptions of social enterprise and social entrepreneurship in Europe and the United States: Convergences and divergences. Journal of Social Entrepreneurship, 1(1), 32-53.

Dey, P., \& Steyaert, C. (2010). The politics of narrating social entrepreneurship. Journal of Enterprising Communities: People and Places in the Global Economy, 4(1), 85-108.

Dey, P., \& Teasdale, S. (2016). The tactical mimicry of social enterprise strategies: Acting "as if" in the everyday life of third sector organizations. Organization, 23(4), 485-504.

Donovan, T. (2009, October 13). Social enterprise needs a profile. Third Sector, p. 13.

Downer, K. (2006, April 19). Social entrepreneurs: Hard heads, high minds. Third Sector, p. 28.

Drayton, B. (2006). The citizen sector transformed. In A. Nicholls (Ed.), Social Entrepreneurship : New Models of Sustainable Social Change (pp. 4555). Oxford: Oxford University Press.

EKOS. (2014). Social Enterprise Mapping Study. Retrievied from https://www. google.pl/url?sa=t\&rct=j\&q=\&esrc=s\&source=web\&cd=1\&cad=rja\&u act $=8 \&$ ved=0ahUKEwjJjK-nmqHaAhXIdCwKHamNDkgQFggsMAA\&url

Social Entrepreneurship and Social Enterprise Phenomenon: Antecedents, Processes, Impact across Cultures and Contexts

Marzena Starnawska and Agnieszka Brzozowska (Eds.) 
=https\%3A\%2F\%2Fhttps://www.biglotteryfund.org.uk/-/media/Files/ Research\%20Documents/er_eval_social_enterprise_mapping_study.pdf Elkington, J., \& Hartigan, P. (2008). The Power of Unreasonable People: How Social Entrepreneurs Create Markets That Change the World. Brighton: Harvard Business School Press.

Fereday, J., \& Muir-Cochrane, E. (2006). Demonstrating rigor using thematic analysis: A hybrid approach of inductive and deductive coding and theme development. International Journal of Qualitative Methods, 5(1), 80-92.

Findlay, L. (2013, August 5). Finding genuine social value. Local Government Chronicle (LGC).

Finn, W. (2004, February). Soul Traders. Director, 58-62.

Fowler, A. (2000). NGDOs as a moment in history: Beyond aid to social entrepreneurship or civic innovation? Third World Quarterly, 21(4), 637-654.

Garet, L. (2014, July 4). Social entrepreneurship: for profit businesses ending hunger and malnutrition. M2 PRESSWIRE.

Garrow, E.E., \& Hasenfeld, Y. (2014). Social enterprises as an embodiment of a neoliberal welfare logic. American Behavioral Scientist, 58(11), 14751493.

Glaser, B.G., \& Strauss, A.L. (1967). The Discovery of Grounded Theory: Strategies for Qualitative Research. Chicago: Aldine Pub.

Grenier, P. (2008). The role and significance of social entrepreneurship in UK social policy. London: London School of Economics.

Grenier, P. (2009). Social entrepreneurship in the UK: From rhetoric to reality? In R. Ziegler (Ed.), An Introduction to Social Entrepreneurship: Voices, Preconditions, Contexts (pp. 174-206). Cheltenham : Edward Elgar.

Grewal, H. K. (2008, October 3). "Few know" about social enterprise. Regeneration \& Renewal, p. 7.

Haigh, N., Walker, J., Bacq, S., \& Kickul, J. (2015). Hybrid organizations: Origins, strategies, impacts and implications. California Management Review, 57(3), 5-12.

Harding, R. (2004). Social enterprise: The new economic engine? Business Strategy Review, 15(4), 39-43.

Hazenberg, R., Bajwa-Patel, M., Roy, M.J., Mazzei, M., \& Baglioni, S. (2016). A comparative overview of social enterprise "ecosystems" in Scotland and England: An evolutionary perspective. International Review of Sociology, 26(2), 205-222.

Hill, T.L., Kothari, T.H., \& Shea, M. (2010). Patterns of meaning in the social entrepreneurship literature: A research platform. Journal of Social Entrepreneurship, 1(February), 5-31.

Hoogendoorn, B., Pennings, E., \& Thurik, R. (2010). What do we know about social entrepreneurship: An analysis of empirical research. report series: research in management. Retrievied from https://repub.eur.nl/ pub/16558/ERS-2009-044-ORG.pdf 
Huberman, M.A., \& Miles, M.B. (2002). The Qualitative Researcher's Companion. Thousand Oaks, [Calif.]: SAGE.

Huckfield, L. (2014). The Rise and Influence of Social Enterprise, Social Investment and Public Service Mutuals (July No. Working Paper 3).

Huybrechts, B., \& Nicholls, A. (2012). Social entrepreneurship: definitions, drivers and challenges. In C.K. Volkmann, K.O. Tokarski \& K.Ernst (Eds.), Social Entrepreneurship and Social Business (pp. 31-48). Germany: Gabler Verlag.

Jolly, R. (2012, June 7). Social enterprise. Liverpool Post, p. 36.

Jones, D., \& Keogh, W. (2006). Social enterprise: A case of terminological ambiguity and complexity. Social Enterprise Journal, 2(1), 11-26.

Kerlin, J. (2013). Defining social enterprise across different contexts. A conceptual framework based on institutional factors. Nonprofit and Voluntary Sector Quarterly, 42(1), 84-108.

Leadbeater, C. (1997). The Rise of the Social Entrepreneur. London: Demos.

Lehner, O.M., \& Kansikas, J. (2013). Pre-paradigmatic status of social entrepreneurship research: A systematic literature review. Journal of Social Entrepreneurship, 4(2), 198-219.

Little, M., \& Warrell, H. (2007, February 7). Is it time to be more enterprising? Third Sector.

Mair, J., \& Martí, I. (2006). Social entrepreneurship research: A source of explanation, prediction, and delight. Journal of World Business, 41(1), 36-44.

Martin, R. L., \& Osberg, S. R. (2007). Social entrepreneurship: The case for definition. Stanford Social Innovation Review.

McCurry, P. (2005, January 19). enterprise culture - where social benefit meets business. Third Sector, p. 26.

Morrison, S. (2013, July 14). Special report: Social entrepreneurship - it's boom time for businesses with heart; They are diverse, dynamic - and doing well in the market. And now social enterprises are to get their own "champion." Independent.co.uk, p..

Muñoz, S. (2009). Social enterprise and public sector voices on procurement. Social Enterprise Journal, 5(1), 69-82.

Nicholls, A. (2006). Introduction. In A. Nicholls (Ed.), Social Entrepreneurship : New Models of Sustainable Social Change (pp. 1-35). Oxford: Oxford University Press.

Nicholls, A. (2010). The legitimacy of social entrepreneurship: Reflexive isomorphism in a pre-paradigmatic field. Entrepreneurship Theory and Practice, 44(0), 611-634.

Palmer, P. (2006, May 10). Social enterprise: new spin, old story. Third Sector, p. 21.

Peredo, A.M., \& McLean, M. (2006). Social entrepreneurship: A critical review of the concept. Journal of World Business, 41, 56-65.

Perrini, F. (2006). Social entrepreneurship domain: Setting boundaries. In F. Perrini (Ed.), The New Social Entrepreneurship: What Awaits Social

Social Entrepreneurship and Social Enterprise Phenomenon: Antecedents, Processes, Impact across Cultures and Contexts

Marzena Starnawska and Agnieszka Brzozowska (Eds.) 
Entrepreneurial Ventures? (pp. 1-25). Cheltenham: Edward Elgar Publishing Limited.

Pharoah, C. (2012, May 1). In my view - Heed the case of Linda Kirk who tried and failed to get local social investment. Third Sector, p. 13.

Plummer, J. (2005, January 12). The next decade: Don't stop now. Third Sector, p. 26.

Reid, K., \& Griffith, J. (2006). Social enterprise mythology: Critiquing some assumptions. Social Enterprise Journal, 2(1), 1-10.

Richardson, M. (2016,). Can social enterprise go truly global?; The Middle East and North Africa is a challenging region for social enterprise. Despite this there are some impressive examples of social enterprise already tackling the multiplicity of problems being faced there. The Guardian, p. Partner zone.

Ridley-Duff, R.J., \& Southcombe, C. (2012). The social enterprise mark: A critical review of its conceptual dimensions. Social Enterprise Journal, 8(3), 178-200.

Schwartz, R. (2012, March 20). Competitions offer social enterprises worthy prizes. Third Sector, p. 19.

Schwartz, R. (2013, June 4). We must get investors onto the ladder of social finance. Third Sector, p. 19.

Seanor, P., \& Meaton, J. (2007). Making sense of social enterprise. Social Enterprise Journal, 3(1), 90-100.

Sen, P. (2007). Ashoka's big idea: Transforming the world through social entrepreneurship. Futures, 39(5), 534-553.

Sepulveda, L. (2015). Social Enterprise - A new phenomenon in the field of economic and social welfare? Social Policy \& Administration, 49(7), $842-861$.

Simms, J. (2008, June). Moral behaviour. Director, 52-55.

Social Enterprise Mark. (2009). Checklist. Retrieved February 6, 2017, from http://www.socialenterprisemark.org.uk/assessment/\#checklist

Social Enterprise UK. (2013). About social enterprises - FAQs. Retrieved May 22, 2017, from https://www.socialenterprise.org.uk/Pages/FAQs/ Category/FAQs

Teasdale, S. (2012). What's in a name? Making sense of social enterprise discourses. Public Policy and Administration, 27(2), 99-119.

Temple, N. (2014, January 21). Social investment should break through this year. Third Sector, p. 19.

Third Sector Magazine. (2013, January 15). Seven days in the sector: SEUK unveils identity badges. Third Sector, p. 6 .

Third Sector Magazine. (2015, July 1). Two friends who woke up and smelled the coffee. Third Sector, p. 62.

UK government. (2015). Social enterprise insights Annex 3 - Partners and key players. Retrieved February 8, 2015, from https://data.gov.uk/data/ contracts-finder-archive/download/1699299/42395221-d0c3-45318736-293a195aa784 
Vasi, I.B. (2009). New heroes, old theories? Toward a sociological perspective on social entrepreneurship. In R. Ziegler (Ed.), An introduction to Social Entrepreneurship: Voices, Preconditions, Contexts (pp. 155-173). Cheltenham, UK : Edward Elgar.

Villa, M. (2016, September 15). Social entrepreneurship, where the glass ceiling is already smashed. The Evening Standard (London), p. 15.

Villeneuve-Smith, F., Temple, N., Brown, B., Gregory, D., \& BMG Research. (2015). State of Social Enterprise Survey 2015.

Warrell, H. (2008, July 30). Social enterprises categorised. Third Sector, p. 3. Young, R. (2004, October 13). The seeds are sown for social entrepreneurs. Third Sector, p. 16.

Zietsma, C., \& Lawrence, T. B. (2010). Institutional work in the transformation of an organizational field: The interplay of boundary work and practice work. Administrative Science Quarterly, 55(2), 189-221.

\begin{abstract}
Abstrakt
Koncepcja przedsiębiorczości społecznej od zawsze była kwestionowana, zarówno $w$ dyskursie akademickim, jak i wśród praktyków. Badacze wkładajq wiele wysiłku $w$ analizę odmiennych definicji przedsiębiorczości społecznej i negatywnego wpływu takiej debaty na przedsiębiorczość społecznq jako pola badawczego. Bardzo niewiele wiadomo na temat konsekwencji wielorakiego rozumienia przedsiębiorczości społecznej dla ludzi pracujqcych $w$ tym sektorze $i$ innych interesariuszy. Niniejsza praca poświęcona jest opisowi badania jakościowego, które miało na celu pokazanie co pracownicy sektora przedsiębiorczości społecznej w Anglii sqdzq na jej temat i jak postrzegajq jej niejasne granice. Wyniki pokazujq, że w Anglii funkcjonujq trzy różne koncepcje przedsiębiorczości społecznej. I choć wszyscy zgadzajq się na obecność debaty definicyjnej, to opinie na temat konsekwencji dla tego sektora jest kilka. Niektórzy członkowie uważajq, że niesie to ze sobq pozytywne konsekwencje, część uważa raczej odwrotnie, a jeszcze inni uważajq, że debata ta nie ma większego znaczenia.
\end{abstract}

Słowa kluczowe: przedsiębiorczość społeczna, definicje, przedsiębiorstwo społeczne, przedsiębiorca społeczny, UK, Anglia.

\title{
Biographical note
}

Tanya Collavo is a Ph.D. student in Management Research at Said Business School, Oxford University, where she studies brokerage and institutional strategies in the social entrepreneurship sector. Her research interests focus on the theoretical intersection between networks and brokerage and institutional theory, with specific emphasis on new sectors such as social entrepreneurship, the sharing economy or sustainable business. She currently serves as teaching assistant for the MBA Rethinking Business course and as tutor for the undergraduate course in Strategy and Innovation. 


\title{
A New Runway for Journalists: On the Intentions of Journalists to Start Social Enterprises
}

\section{Huei-Ching Liu', Ching Yin Ip², Chaoyun Liang ${ }^{3}$}

\begin{abstract}
Journalists have been facing a variety of challenges and are even being laid off in the face of changing media ecosystems in the age of digital convergence. Sharing similar characteristics with entrepreneurs, numerous journalists have worked together to develop social enterprises, attaining social change through business approaches. The present study explores the intentions of former and current journalists to establish social enterprises, using questionnaires focused on personality traits, creativity, and social capital. Results reveal that creativity was found to have a significant influence on the social entrepreneurial intentions of journalists, as does having higher bridgingtype social capital.
\end{abstract}

Keywords: creativity, entrepreneurial intention, personality traits, social capital, social enterprise.

\section{INTRODUCTION}

In this era of digital convergence, people freely upload their texts, images, and videos to social media platforms. The subsequent aggregation of people and information on the Internet has garnered attention from journalists, who then use the contents posted online as news sources (Burgess \& Green, 2009, p. 15). Newman, Dutton, and Blank (2012) reported that the information from social media had been adopted by journalists to strengthen their news production and dissemination roles. Therefore, newspapers, broadcasts, and television are closely integrated with the Internet, which has changed the

\footnotetext{
1 Huei-Ching Liu, Research Assistant, Department of Bio-Industry Communication and Development, National Taiwan University, Taipei, No. 1, Sec. 4, Roosevelt Road, Taipei, 10617, Taiwan; e-mail: audreyliou@gmail.com

2 Ching Yin Ip, Research Assistant, Department of Bio-Industry Communication and Development, National Taiwan University, Taipei, No. 1, Sec. 4, Roosevelt Road, Taipei, 10617, Taiwan; e-mail: ipchingyin@yahoo.com.hk.

3 Chaoyun Liang, Professor, Department of Bio-Industry Communication and Development, National Taiwan University, Taipei, No. 1, Sec. 4, Roosevelt Road, Taipei, 10617, Taiwan; e-mail: cliang@ntu.edu.tw.
} 
conventional media ecology. Anyone can become a news producer, producing a massive challenge to the professional status of journalists.

This aggregation of the media ecology has caused a series of layoffs worldwide over the previous five years. Sanlih E-Television in Taiwan, which is actively transitioning into a new medium, laid off 150 of its workers in 2014, whereas TVBS, the first cable television company in Taiwan, announced that only senior reporters aged over 45 years may apply for its retirement plan. In the United Kingdom, many full-time journalistic jobs have been changed into contract or freelance jobs (Storey, Salaman \& Platman, 2005). In the United States, the volume of advertisements in conventional paper media dropped 48\% from 2006 to 2010, and news jobs have decreased by $36 \%$ in the past decade (Smith, 2012). The media industry has thus been stalled and many journalists, forced to leave their jobs, must find alternate career paths. Numerous laid-off reporters have worked together to develop social enterprises, attaining social change through business approaches.

Journalists share several similar characteristics with entrepreneurs, such as their curiosity about new things, their ability to view the world from different perspectives, and their interactions with people at various levels (McManus, 2015). Studies have reported that personality traits influence individuals' entrepreneurial intentions and behaviors (Brandstätter, 2011; Collins, Hanges \& Locke, 2004; Zhao, Seibert \& Lumpkin, 2010). Accordingly, people who are extroverted, open to new experiences, conscientious, yet have low neuroticism and agreeableness tend to possess strong entrepreneurial intentions. In addition, entrepreneurs in the knowledge economy must possess excellent creativity (Carayannis, Popescu, Sipp \& Stewart, 2006). Similarly, social capital strongly influences people's entrepreneurial intentions (Liñán \& Santos, 2007). Therefore, the present study explores the effects of personality traits, creativity, and social capital on the social entrepreneurial intentions of journalists.

\section{LITERATURE REVIEW}

\section{Social enterprises and entrepreneurial intentions}

Social enterprises are those created for social welfare and attained social change through innovation (Pelchat, 2005). Social entrepreneurs provide nonprofit job opportunities, cultivate a service workforce, and promote their positions on society, the environment, and public welfare through business approaches (Vitiello \& Wolf-Powers, 2014). Social entrepreneurs must be capable of creating social and economic value as well as long-term selfsufficiency. This value involves preserving sociocultural heritage, satisfying 
recreational and aesthetic needs, and promoting economic functions to generate goods and services (Mander, Wiggering \& Helming, 2007). Smith (2012) reported that numerous journalists who left their media jobs for entrepreneurship have aimed to change the world. In particular, $71 \%$ of the journalists indicated that the importance of conventional media will drop in five years, and $84 \%$ believe that social enterprises will become increasingly vital, and that news companies will also transition into social enterprises.

Entrepreneurial intentions can be defined as the conviction and preparation required for constructing a new enterprise or increasing the value of an existing enterprise, and the determination for continual planning (Thompson, 2009). Entrepreneurial intentions also play a mediating role in triggering action (Fayolle, Gailly \& Lassas-Clerc, 2006). The entrepreneurial intentions of small, medium, and non-profit enterprises vary from those of general for-profit enterprises and require separate research perspectives, arguments, and practices for analysis (Pittaway \& Cope, 2007). The entrepreneurial intentions of social entrepreneurs involve increasing social capital and strengthening community cohesion, and are therefore distinct from those of business entrepreneurs (Mair \& Noboa, 2006). According to prior research (Lans, Gulikers \& Batterink, 2010; Liñán \& Chen, 2009), Wang, Peng and Liang (2014) developed an entrepreneurial intention scale with high reliability and validity. This scale categorized entrepreneurial intentions into two factors, namely conviction and preparation.

\section{Personality traits versus entrepreneurial intentions}

Personality traits are a type of stable tendency that reveal the distinct patterns of thought, emotion, and behavior of each individual (Costa \& McCrae, 1992). These unique traits are expressed in the physical and psychological characteristics of individuals through interactions among genetic, environmental, and learning factors, and are considered to be integrated and persistent (Liang, Chia, \& Liang, 2015). The five-factor model is a personality theory that has currently been stably developed in international academia. According to this model, personality traits involve five major factors, namely extraversion, openness to experience, neuroticism, conscientiousness, and agreeableness. Hollifield, Kosicki, and Becker (2001) indicated that journalistic employers prioritized the personality traits and work habits of their employees over their professionalism.

The personality traits of journalists are associated with entrepreneurship (Brandstätter, 2011; Collins et al., 2004; Zhang, 2008). Generally, they are extraverted, independent and open to new experiences (Henningham, 1997; Siu \& Lo, 2013). They usually possess high self-confidence (Chen, Greene, \& Cricke, 1998) and firmly believe in their own capabilities to adapt to the 
external environment and control their performance (Simon, Houghton \& Aquino, 2000). These traits define low levels of neuroticism. They commonly hold strong achievement motivations; in other words, they are typically conscientious (Collins et al., 2004; Stewart \& Roth, 2004). They are confronted by limited resources, insufficient legal protection, and substantial financial risks, thus becoming more competitive and less agreeable (Zhao \& Seibert, 2006). Recent meta-analysis studies have reported that people with strong entrepreneurial intentions are extroverted, open to new experiences, and conscientious, but are also less neurotic and agreeable than other people (Brandstätter, 2011; Zhao et al., 2010). The current study aimed to acknowledge the correlations between identified variables rather than determine their causal relationships. In the end, whether these correlations are positive or negative will be theory-driven and depend on the following measurement analyses. On the basis of the aforementioned studies, we proposed the first two hypotheses:

H1. Extraversion, openness, and conscientiousness are positively related to social entrepreneurial intentions.

H2. Neuroticism and agreeableness are negatively related to social entrepreneurial intentions.

\section{Creativity versus entrepreneurial intentions}

According to Barron and Harrington (1981), creativity is defined from two distinct perspectives: the product perspective, which regards creativity as new products with socially recognized achievements (Baer, Kaufman, \& Gentile, 2004; Hennessey \& Amabile, 2010), and the competency perspective, which refers to creativity as the competencies expressed by individuals in specific tasks (Fryer, 2006). Both perspectives involve two core concepts, namely originality and usefulness (Runco \& Jaeger, 2012). In aggregating previous studies, the originality of creativity implies the ability to produce a novel or uncommon idea, behavior, or work, and that the usefulness of creativity implies the ability to produce an appropriate, effective, or valuable idea, behavior, or work. Both must be accepted in the specific societal context (Amabile, 1997; Lin, Hsu \& Liang, 2014; Runco \& Jaeger, 2012). Cropley (2015) maintained that creativity must involve the qualities of elegance and genesis. The arguments by Lin et al. (2014) and Cropley (2015) were adopted in this study for developing a research instrument.

Prior research has determined that creativity is a critical motivator of entrepreneurial intentions, and proactive and creative people exhibit high levels of entrepreneurial desirability (Balachandran \& Sakthivelan, 2013; Zampetakis, 2008). Creative people tend to take more risks and

Social Entrepreneurship and Social Enterprise Phenomenon: Antecedents, Processes, Impact across Cultures and Contexts

Marzena Starnawska and Agnieszka Brzozowska (Eds.) 
are more impulsive, independent, and intrinsically motivated. They also see themselves as more competent, hard-working, persistent, and gritty (Kaufman, 2011). The climate for innovation on campus can increase the entrepreneurial intentions of teachers and students (Lee, Wong, Foo \& Leung, 2011). In investigating students attending elective journalistic courses at school, the desire to express creativity through various lifestyles and opportunities was identified as students' primary motivation for attending these courses (Hanusch et al., 2016). Similarly, most in-service journalists enjoy being creative, possess strong creativity, and exhibit higher social entrepreneurial intentions than do ordinary people (Lee \& Min, 2016). In addition, student imagination and creativity have considerable influences on ventures and rural service (Chang, Yao, Chen, King \& Liang, 2016; Yao, Peng, Lee \& Liang, 2016). Based on these studies, the following hypothesis was proposed:

H3. Creativity is positively related to social entrepreneurial intentions.

\section{Social capital versus entrepreneurial intentions}

Social capital can be defined as the relationship networks that can be effectively mobilized and the totality of the resources owned by all members in the networks (Bourdieu, 1986). The social capital owned by each individual determines the position of the individual in a group, affects the types and quantities of social resources available to the individual, and defines the opportunity for the individual to access these resources (Lin, 2002). Social capital enhances entrepreneurial activities, particularly knowledge acquisition, business opportunity identification, relational connections, reputation establishment, and performance improvement (Lechner \& Dowling, 2003; Partanen, Kristian, Westerlund, Rajala \& Rajala, 2008; Shaw, Lam \& Carter, 2008).

Putnam (2000) indicated that social capital could be categorized into two dimensions, namely bonding and bridging. Bonding social capital refers to strong ties with family and friends who may provide emotional support or access to scarce resources. Bridging social capital refers to weak ties among individuals connected across different social networks and providing new perspectives. Correspondingly, Williams (2006) conceptualized and developed a social capital assessment scale containing 20 items. Furthermore, Liñán and Santos (2007) determined that higher social capital generates higher entrepreneurial intentions.

Media frequently play a role in bridging communities with social capital, facilitating communications among the diverse groups in the communities and promoting social welfare, thus enhancing the development of social 
capital (Richards, 2013). The rise of the Internet has facilitated a new ecology of communications, and the online interactions strengthen community connections and enable the extensions of external relationships (Joinson, 2003). Through the mediation of emerging communication technology, Huysman and Wulf (2004) indicated that interpersonal networks can be established, and social capital can be accumulated. Currently, the most frequently employed communication technology is social media, which is most profoundly and positively associated with social capital (Valenzuela, Park \& Kee, 2009). Journalists frequently rely on social media to collect information, maintain relationships, and perform interactive communications. Journalists, as a group, accumulate social capital for social entrepreneurship the most easily. The aforementioned studies lead to the final two correlational hypotheses:

H4. Bonding social capital is positively related to social entrepreneurial intentions.

H5. Bridging social capital is positively related to social entrepreneurial intentions.

\section{METHODS}

\section{Samples}

By conducting an online questionnaire, we studied factors influencing the intentions of former or current journalists to start social enterprises. All participants were former or current journalists. Descriptive statistics obtained by analyzing the percentage frequency distribution of the participants' demographic data are listed in Table 1:

Table 1. Descriptive analysis of Study $1(n=401)$

\begin{tabular}{lllllll}
\hline Variables & \multicolumn{6}{l}{ Descriptions } \\
\hline Gender & 205 men & \multicolumn{5}{l}{ 196 women } \\
Age & $\begin{array}{l}\text { 25 or } \\
\text { younger }\end{array}$ & $26-30$ & $31-35$ & $36-40$ & $41-45$ & 46 or older \\
& 25 & 31 & 77 & 97 & 112 & 59 \\
\multirow{4}{*}{ Seniority } & $<1$ year & $1-3$ & $4-6$ & $7-9$ & $10-12$ & $>13$ years \\
& 18 & 55 & 40 & 36 & 71 & 181 \\
\hline
\end{tabular}




\section{Measurements}

In Part 1, personality was measured using a simplified version of the Big Five personality traits model developed by Thompson (2008). We adapted the original English-language inventory, which consisted of 40 items, into a 20-item Chinese-language questionnaire based on the factor loadings of the inventory. In Part 2, creativity was measured using results from Lin et al. (2014) and Cropley (2015). Specifically, creativity was divided into two aspects: originality and usefulness. In Part 3, social capital was measured using the Social Capital Scales devised by Williams (2006). The original scales comprised of 20 items measuring two types of social capital, namely, bridging- and bonding-type social capital. For this study, we selected the 10 items featuring the highest factor loadings. In Part 4, social entrepreneurial intentions were measured using 8 items rearranged on the basis of Wang, Peng, and Liang (2014). The questionnaire for this study adopted a 6-point Likert-type scale, with strongly agree $=6$, agree $=5$, somewhat agree $=4$, somewhat disagree $=3$, disagree $=2$, and strongly disagree $=1$.

\section{Procedures}

The questionnaires were distributed between October 1, 2016, and November 5,2016 , through online social media groups formed by journalists. The design of the online questionnaire system requires participants to complete all items before proceeding to the next page; therefore, no missing items and thus no missing values existed. A questionnaire was deemed invalid if the responses to all items were similar or if responses to reverse items were illogical. Ultimately we collected 445 questionnaires and obtained 401 valid samples after removing 40 invalid samples.

\section{RESULTS}

\section{Exploratory factor analysis}

Factors used in the exploratory factor analysis were required to have an eigenvalue greater than 1 and a factor loading greater than .3. Table 2 shows that regarding personality traits, results from Bartlett's sphericity test all reached a level of significance $\left(\chi^{2}=2549.869 ; p<.001\right)$ and the Kaiser-MeyerOlkin (KMO) measure of sampling adequacy was .743, indicating the factors could be employed to conduct a factor analysis. The test results showed that five factors could be extracted from the 20 items, with a total cumulative variance explained of $58.020 \%$. Therefore, the 20 items for personality traits can be divided into the following five constructs: extraversion, openness to experience, neuroticism, conscientiousness, and agreeableness. 
Table 2. Factor loading, M, SD, Cronbach's $\alpha$, and percentage of variance of personality traits

\begin{tabular}{|c|c|c|c|c|c|c|c|c|c|}
\hline Factor/Item & EX & OP & NE & $\mathrm{CO}$ & AG & $M$ & $S D$ & $\alpha$ & $\begin{array}{l}\% \text { of } \\
\text { variance }\end{array}$ \\
\hline Extraversion (EX) & & & & & & & & .90 & 14.32 \\
\hline Talkative & .759 & & & & & 4.40 & .96 & .80 & \\
\hline Outgoing & .820 & & & & & 4.17 & 1.02 & .79 & \\
\hline Reserved & .844 & & & & & $3.77^{*}$ & 1.02 & .78 & \\
\hline Shy & .803 & & & & & $3.98^{*}$ & 1.03 & .82 & \\
\hline Open to experience & & & & & & & & .80 & 14.07 \\
\hline \multicolumn{10}{|l|}{ (OP) } \\
\hline Creative & & & .820 & & & 4.38 & .89 & .55 & \\
\hline Philosophical & & .415 & .704 & & & 4.72 & .85 & .65 & \\
\hline Unimaginative & & & .529 & & & $4.31 *$ & 1.02 & .61 & \\
\hline Unintellectual & & .421 & .426 & & & $4.44^{*}$ & .97 & .61 & \\
\hline Neuroticism (NE) & & & & & & & & .78 & 9.95 \\
\hline Anxious & & & & .607 & -.343 & 3.88 & 1.27 & .59 & \\
\hline Jealous & & & & .565 & & 2.73 & 1.01 & .59 & \\
\hline Unworried & & & & .804 & & $3.78^{*}$ & 1.14 & .49 & \\
\hline Unenvious & & & & .713 & & $3.32 *$ & 1.05 & .61 & \\
\hline Conscientiousness & & & & & & & & .86 & 9.87 \\
\hline \multicolumn{10}{|l|}{ (CO) } \\
\hline Systematic & & .781 & & & & 4.41 & .86 & .71 & \\
\hline Careful & & .677 & & & & 4.25 & .96 & .74 & \\
\hline Disorganized & & .781 & & & & $4.50 *$ & .91 & .70 & \\
\hline Inefficient & & .787 & & & & $4.70^{*}$ & .90 & .75 & \\
\hline Agreeableness (AG) & & & & & & & & .76 & 9.78 \\
\hline Sympathetic & & & & & .481 & 4.80 & .86 & .56 & \\
\hline Not harsh & & & & & .608 & 4.10 & 1.08 & .54 & \\
\hline Unkind & & & & & .725 & $4.60 *$ & 1.03 & .48 & \\
\hline Rude & & & & & .717 & $3.59 *$ & 1.27 & .55 & \\
\hline $\begin{array}{l}\text { Total variance } \\
\text { explained }\end{array}$ & & & & & & & & & 58.020 \\
\hline
\end{tabular}

Results in Table 3 show that, regarding creativity, results from Bartlett's sphericity test did not reach a level of significance. Consequently, the factors cannot be used to perform a factor analysis, but the 12 items were used as a construct with a cumulative variance explained of $65.155 \%$.

Table 3. Factor loading, M, SD, Cronbach's $\alpha$, and percentage of variance of creativity

\begin{tabular}{llllll}
\hline Item & Creativity & $M$ & $S D$ & $\alpha$ & $\begin{array}{l}\text { \% of } \\
\text { variance }\end{array}$ \\
\hline $\begin{array}{l}\text { I can develop an unconventional business } \\
\text { plan }\end{array}$ & .797 & 3.85 & .922 & .903 & \\
\begin{tabular}{l} 
I can develop a unique business plan \\
\hline
\end{tabular} & .803 & 3.79 & .930 & .903 & \\
\hline
\end{tabular}

Social Entrepreneurship and Social Enterprise Phenomenon: Antecedents, Processes, Impact across Cultures and Contexts Marzena Starnawska and Agnieszka Brzozowska (Eds.) 


\begin{tabular}{|c|c|c|c|c|c|}
\hline Item & Creativity & $M$ & $S D$ & $\alpha$ & $\begin{array}{l}\% \text { of } \\
\text { variance }\end{array}$ \\
\hline $\begin{array}{l}\text { I am not good at identifying new market } \\
\text { needs }\end{array}$ & .530 & 3.97* & .909 & .916 & \\
\hline $\begin{array}{l}\text { I am good at proposing innovative ideas } \\
\text { based on market needs }\end{array}$ & .718 & 4.09 & .804 & .907 & \\
\hline $\begin{array}{l}\text { I can develop a business plan that targets } \\
\text { specific market segments }\end{array}$ & .880 & 3.84 & .841 & .899 & \\
\hline $\begin{array}{l}\text { I can develop a business plan that can lead } \\
\text { the market }\end{array}$ & .880 & 3.84 & .841 & .899 & \\
\hline $\begin{array}{l}\text { I can understand the diverse needs of } \\
\text { various customers }\end{array}$ & .665 & 4.31 & .794 & .909 & \\
\hline $\begin{array}{l}\text { I am unable to adapt flexibly to market } \\
\text { changes }\end{array}$ & .385 & $4.23 *$ & .920 & .922 & \\
\hline $\begin{array}{l}\text { I can consider the preference of target } \\
\text { consumers }\end{array}$ & .665 & 4.31 & .794 & .909 & \\
\hline $\begin{array}{l}\text { I can develop a business plan that meets } \\
\text { the target market's demand }\end{array}$ & .830 & 4.00 & .742 & .902 & \\
\hline $\begin{array}{l}\text { I can develop a business plan that attracts } \\
\text { investors' attention }\end{array}$ & .722 & 3.85 & .807 & .907 & \\
\hline $\begin{array}{l}\text { My business plan can adapt to different } \\
\text { markets after adjustments }\end{array}$ & .759 & 3.84 & .810 & .905 & \\
\hline
\end{tabular}

Note: * refers to the fact that the times mean scores of these items were reversed.

Results in Table 4 show that regarding social capital, results from Bartlett's sphericity test reached a level of significance $\left(\chi^{2}=1604.913 ; p<.001\right)$ and the KMO measure of sampling adequacy was .761, indicating that the factors can be employed to conduct a factor analysis. The results showed that two factors can be extracted from the ten items, with a total cumulative variance explained of $64.662 \%$. The ten items can be divided into the following two constructs: bonding and bridging.

Table 4. Factor loading, M, SD, Cronbach's $\alpha$, and percentage of variance of social capital

\begin{tabular}{llllll}
\hline Factor/Item & BON BRI & M & SD & $\alpha$ & $\begin{array}{l}\% \text { of } \\
\text { variance }\end{array}$ \\
\hline $\begin{array}{l}\text { Bonding (BON) } \\
\begin{array}{l}\text { There are several people I trust to help } \\
\text { solve my problems }\end{array}\end{array}$ & .746 & 4.51 & .78 & .64 & 31.84 \\
$\begin{array}{l}\text { There is someone I can turn to for advice } \\
\text { about making very important decisions } \\
\text { If I need an emergency loan of US\$500, } \\
\text { I have no one I can ask }\end{array}$ & .758 & 4.59 & .76 & .63 & \\
\hline
\end{tabular}




\begin{tabular}{|c|c|c|c|c|c|c|}
\hline Factor/Item & BON & BRI & $M$ & $S D$ & $\alpha$ & $\begin{array}{l}\text { \% of } \\
\text { variance }\end{array}$ \\
\hline $\begin{array}{l}\text { The people I interact with would put their } \\
\text { reputation on the line for me }\end{array}$ & .652 & & 3.86 & 1.10 & .68 & \\
\hline $\begin{array}{l}\text { The people I interact with would help me } \\
\text { fight an injustice }\end{array}$ & .675 & & 4.33 & .87 & .65 & \\
\hline Bridging (BRI) & & & & & .75 & 28.91 \\
\hline $\begin{array}{l}\text { Interacting with people makes me } \\
\text { interested in things that happen outside of } \\
\text { my town }\end{array}$ & & .886 & 4.85 & .83 & .63 & \\
\hline $\begin{array}{l}\text { Interacting with people online/offline } \\
\text { makes me want to try new things }\end{array}$ & & .893 & 4.88 & .83 & .63 & \\
\hline $\begin{array}{l}\text { Talking with people does not make me } \\
\text { curious about other places in the world }\end{array}$ & & .567 & $4.62^{*}$ & 1.17 & .79 & \\
\hline $\begin{array}{l}\text { Interacting with people makes me feel part } \\
\text { of a larger community }\end{array}$ & & .403 & 4.10 & 1.06 & .78 & \\
\hline $\begin{array}{l}\text { Interacting with people makes me feel } \\
\text { connected to the bigger picture }\end{array}$ & & .780 & 4.66 & .82 & .67 & \\
\hline Total variance explained & & & & & & 60.75 \\
\hline
\end{tabular}

Note: ${ }^{*}$ refers to the fact that the times mean scores of these items were reversed.

Regarding social entrepreneurial intentions, results from Bartlett's sphericity test reached a level of significance $\left(\chi^{2}=2420.223 ; p<.001\right)$ and the KMO measure of sampling adequacy was .913 , indicating the factors can be employed to conduct a factor analysis (Table 5). The test results showed that the total cumulative variance explained was $65.555 \%$. The eight items for social entrepreneurial intentions were used as a single construct.

Table 5. Factor loading, M, SD, Cronbach's $\alpha$, and percentage of variance of social entrepreneurial intention

\begin{tabular}{|c|c|c|c|c|c|}
\hline Factor/Item & SEI & $M$ & $S D$ & $\alpha$ & $\begin{array}{l}\% \text { of } \\
\text { variance }\end{array}$ \\
\hline \multicolumn{6}{|l|}{ Social entrepreneurial intention (SEI) } \\
\hline $\begin{array}{l}\text { I wish to start a social enterprise that assists in } \\
\text { alleviating environmental issues }\end{array}$ & .912 & 4.09 & 1.06 & .92 & \\
\hline $\begin{array}{l}\text { I have a preliminary idea for a social enterprise } \\
\text { that I plan to implement in the future }\end{array}$ & .895 & 3.57 & 1.08 & .91 & \\
\hline $\begin{array}{l}\text { My professional goal is to become a social } \\
\text { entrepreneur }\end{array}$ & .879 & 3.24 & 1.13 & .90 & \\
\hline $\begin{array}{l}\text { I am willing to do anything to become a social } \\
\text { entrepreneur }\end{array}$ & .864 & 3.26 & 1.21 & .90 & \\
\hline $\begin{array}{l}\text { I expect that at some point in the future, I will be } \\
\text { involved in launching an organization that aims to } \\
\text { promote environmental sustainability }\end{array}$ & .827 & 3.37 & 1.15 & .90 & \\
\hline
\end{tabular}




\begin{tabular}{|c|c|c|c|c|c|}
\hline Factor/Item & SEI & $M$ & $S D$ & $\alpha$ & $\begin{array}{l}\% \text { of } \\
\text { variance }\end{array}$ \\
\hline $\begin{array}{l}\text { I expect that at some point in the future, I will be } \\
\text { involved in launching an organization that aims to } \\
\text { help disadvantaged groups }\end{array}$ & .742 & 3.62 & 1.18 & .90 & \\
\hline
\end{tabular}

I will act as a professional manager and get .6773 .421 .16 .91

involved in the management of a social enterprise through promotion

If I inherit my family's business, I plan on

$.6343 .68 \quad 1.21 .92$

transforming it into a social enterprise

Total variance explained

65.55

\section{Multiple regression analysis of the variables}

The results of a multiple regression analysis found the overall model reached a level of significance $(p<.001)$. In addition, creativity and bridging-type social capital as constructs reached a level of significance $(p<.05)$, whereas constructs under personality traits were nonsignificant (Table 6). Therefore, both $\mathrm{H} 3$ and $\mathrm{H} 5$ were supported, whereas $\mathrm{H} 1, \mathrm{H} 2$, and $\mathrm{H} 4$ were rejected.

Table 6. Multiple regression analysis of the variables

\begin{tabular}{lllll}
\hline Variables & & \multicolumn{3}{l}{ Social Entrepreneurial intentions } \\
\cline { 2 - 5 } & Factors & Beta & $\boldsymbol{t}$ & $\boldsymbol{p}$ \\
\hline \multirow{2}{*}{ Personality Traits } & (Constant) & .386 & .73 & .46 \\
& Extraversion & -.026 & -.46 & .64 \\
& & & & \\
& Openness & -.105 & -1.27 & .20 \\
& Neuroticism & .072 & 1.28 & .20 \\
& Conscientiousness & .008 & .11 & .91 \\
Creativity & Agreeableness & -.010 & -.16 & .87 \\
Social Capital & Bonding & .593 & 6.96 & $.000^{* * *}$ \\
& Bridging & .069 & .92 & .35 \\
Summary & $R^{2}$ & .177 & 2.43 & $.015^{* *}$ \\
& $\mathrm{~F}$ & .180 & & \\
& $p$ & 10.76 & & \\
${ }^{*} p<.05,{ }^{* *} p<.01,{ }^{* * *} p<.001$ & $.000 * * *$ & & \\
\end{tabular}

\section{DISCUSSION}

Our results indicate that the big five personality traits of journalists had no significant influence on their social entrepreneurial intentions. Our hypotheses are built on classic entrepreneurship literature rather than newly emerging social entrepreneurship studies, possibly explaining this result. In addition, we arrived at this finding probably because creativity was included 
as an independent variable. Research has confirmed a strong correlation between personality traits and creativity (Amabile, 1983; Chang, Peng, Lin \& Liang, 2015). The influence of personality traits was probably subsumed by that of creativity.

Prior research has indicated that social entrepreneurs strive to develop creative mechanisms for circumventing environmental barriers (Dacin, Dacin \& Matear, 2010; Shaw \& Carter, 2007). Our results also support the view that creativity positively influenced the social entrepreneurial intentions of Taiwanese journalists, concurring with the findings of previous studies. The finding implies that journalists possessing higher levels of creativity are more confident about working independently to confront difficulties, although journalistic voices are traditionally constricted by norms, narratives, and precedents, leaving little room for creativity (Markham, 2012).

Furthermore, bridging social capital has not often been recognized as a robust antecedent for social entrepreneurial intentions (Lorenz, 2008), suggesting a particular need in the context of journalism for bridging social capital to provide new perspectives and innovative approaches. Valenzuela, Park, and Kee (2009) argued that heavy usage of communications technology has a significant positive correlation with social capital, and most Taiwanese journalists are heavy social media users. This study corroborates the finding of Valenzuela et al. (2009), that heavy usage of social media enables journalists to gain bridging-type social capital, which is beneficial for building social enterprises. Moreover, Hockerts (2017) indicated that prior experience of social work can be used to predict social entrepreneurial intentions. Creativity and social capital are both positively correlated with prior experience (Choi, 2004; Fernandez, Castilla \& Moore, 2000), supporting Hockerts' findings in the case of journalists.

This study has several limitations. It was conducted using convenience sampling, where questionnaires were distributed to journalists in online social groups. Journalists with experience of more than 13 years were overrepresented (181 out of 401 participants), indicating a potential sampling bias. In addition, the target participants were former or current journalists, with no distinction made between the two types of participants. Consequently, we cannot discuss the results based on any specific group. It is not known if the current occupation of former journalists is significant for the results. Furthermore, the communication patterns featured on television, in newspapers, and on the Internet vary, and consequently, so might the impact of divergent media ecologies. However, we do not discuss the results based on the type of media. Finally, the scale used to measure creativity is newly developed and may not be an optimal tool for the purpose of the current study. Creating a business plan may not be a competency of journalists, but 
is nevertheless essential for journalists to initiate a new social venture. Using a measurement tool more adjusted to participants would be advisable in future research.

Considering these limitations, we recommend the following directions for future research. (1) Regarding how journalists actually function in social enterprises, long-term tracking and observation should be conducted to examine whether the personality traits, creativity, and social capital of former and current journalists, as two separate groups, significantly influence their social entrepreneurial behaviors; (2) Studies can separately investigate journalists currently or previously in television, newspapers, and Internet media. (3) In-depth studies should be conducted to explore the personality traits, creativity, and social capital of former journalists who have left the industry and built social enterprises, to examine whether the three variables affect the business models of the social enterprises.

The results of this study show that given the aggregation of conventional media in the context of digital convergence, the creativity and social capital possessed by journalists provides an advantage for them to build social enterprises as an alternative professional path. Our model for evaluating social enterprise creation may benefit both scholars and journalists as a basis for identifying business partners in the creation and development of diverse social enterprises in various media ecologies. Furthermore, where previous creativity research has focused exclusively on general enterprises, this study offers more nuance.

\section{Acknowledgments}

The authors would like to express their gratitude for the insightful suggestions of anonymous JEMI reviewers.

\section{References}

Amabile, T.M. (1983). The social psychology of creativity: A componential conceptualization. Journal of Personality and Social Psychology, 45(2), 357-376.

Amabile, T.M. (1997). Entrepreneurial creativity through motivational synergy. Journal of Creative Behavior, 31(1), 18-26.

Astone, N.M., Nathanson, C.A., Schoen, R., \& Kim, Y.J. (1999). Family demography, social theory, and investment in social capital. Population and Development Review, 25(1), 1-31.

Baer, J., Kaufman, J.C., \& Gentile, C.A. (2004). Extension of the consensual assessment technique to nonparallel creative products. Creativity Research Journal, 16(1), 113-117. 
Balachandran, V., \& Sakthivelan, M.S. (2013). Impact of information technology on entrepreneurship (e-entrepreneurship). Journal of Business Management \& Social Sciences Research, 2(2), 51-56.

Barron, F., \& Harrington, D.M. (1981). Creativity, intelligence, and personality. Annual Review of Psychology, 32(1), 439-476.

Bourdieu, P. (1986). The forms of capital. In J. G. Richardson (Ed.), Handbook of Theory and Research for the Sociology of Education (pp. 241-258). New York: Greenwood Press.

Brandstätter, H. (2011). Personality aspects of entrepreneurship: A look at five meta-analyses. Personality and Individual Differences, 51(3), 222-230.

Burgess, J., \& Green, J. (2009). YouTube: Online Video and Participatory Culture (p. 15). Cambridge, UK: Polity.

Carayannis, E.G., Popescu, D., Sipp, C., \& Stewart, M. (2006). Technological learning for entrepreneurial development (TL4ED) in the knowledge economy (KE): Case studies and lessons learned. Technovation, 26(4), 419-443.

Chang, C.-C., Peng, L.-P., Lin, J.-S., \& Liang, C. (2015). Predicting the creativity of design majors from the interaction of diverse personality traits. Innovations in Education and Teaching International, 52(4), 371-382.

Chang, C.-C., Yao, S.-N., Chen, S.-A., King, J.-T., \& Liang, C. (2016). Imagining garage startups: Interactive effects of imaginative capabilities on technopreneurship intention. Creativity Research Journal, 28(3), 289-297.

Chen, C.C., Greene, P.G., \& Crick, A. (1998). Does entrepreneurial self-efficacy distinguish entrepreneurs from managers? Journal of Business Venturing, 13(4), 295-316.

Choi, J. N. (2004). Individual and contextual predictors of creative performance: The mediating role of psychological processes. Creativity Research Journal, 16(2/3), 187-199.

Collins, C.J., Hanges, P., \& Locke, E.A. (2004). The relationship of need for achievement to entrepreneurship: A meta-analysis. Human Performance, 17(1), 95-117.

Costa, P.T., \& McCrae, R.R. (1992). NEO PI-R. Professional manual. Odessa, FL: Psychological Assessment Resources.

Cropley, A.J. (2015, April). Transferable criteria of creativity: A universal aesthetic. Paper presented at the New Zealand Creativity Challenge: Creativity crosses boundaries, Wellington, NZ.

Dacin, P. A., Dacin, M. T., \& Matear, M. (2010). Social entrepreneurship: Why we don't need a new theory and how we move forward from here. The Academy of Management Perspectives, 24(3), 37-57.

Fayolle, A., Gailly, B., \& Lassas-Clerc, N. (2006). Assessing the impact of entrepreneurship education programmes: A new methodology. Journal of European Industrial Training, 30(9), 701-720.

Fernandez, R. M., Castilla, E. J., \& Moore, P. (2000). Social capital at work: Networks and employment at a phone center. American Journal of Sociology, 105(5), 1288-1356. 
Fryer, M. (2006). Making a difference: A tribute to E. Paul Torrance from the United Kingdom. Creativity Research Journal, 18(1), 121-128.

Hanusch, F., Clifford, K., Davies, K., English, P., Fulton, J., Lindgren, M., O'Donnell, P., Price, J., Richards, I., \& Zion, L. (2016). For the lifestyle and a love of creativity: Australian students motivations for studying journalism. Media International Australia, 160(1), 101-113.

Hennessey, B.A., \& Amabile, T.M. (2010). Creativity. Annual Review of Psychology, 61(1), 569-598.

Henningham, J. (1997). The journalist's personality: An exploratory study. Journalism \& Mass Communication Quarterly, 74(3), 615-624.

Hockerts, K. (2017). Determinants of social entrepreneurial intentions. Entrepreneurship Theory and Practice, 41(1), 105-130

Hollifield, C. A., Kosicki, G. M., \& Becker, L. B. (2001). Organizational vs. professional culture in the newsroom: Television news directors' and newspaper editors' hiring decisions. Journal of Broadcasting \& Electronic Media, 45(1), 92-117.

Huysman, M., \& Wulf, V. (2004). Social capital and information technology: Current debates and research. Social Capital and Information Technology (pp. 1-15). Cambridge, MA: The MIT Press.

Joinson, A.N. (2003). Sharing and surfing: The benefits of on-line communities and web browsing. In Understanding the Psychology of Internet Behaviour: Virtual Worlds, Real Lives (pp. 143-162). New York: Palgrave Macmillan.

Kaufman, S. B. (2011). Is conscientiousness compatible with creativity? Creative people are both conscientious and not conscientious at the same time. Retrieved 25 March 2017 from https://www. psychologytoday.com/blog/beautiful-minds/201108/is-conscientio usness-compatible-creativity

Lans, T., Gulikers, J., \& Batterink, M. (2010). Moving beyond traditional measures of entrepreneurial intentions in a study among life-sciences' students in the Netherlands. Research in Post-Compulsory Education, 15(3), 259-274.

Lechner, C., \& Dowling, M. (2003). Firm networks: External relationships as sources for the growth and competitiveness of entrepreneurial firms. Entrepreneurship \& Regional Development, 15(1), 1-26.

Lee, L., Wong, P. K., Foo, M. D., \& Leung, A. (2011). Entrepreneurial intentions: The influence of organizational and individual factors. Journal of Business Venturing, 26(1), 124-136.

Lee, S.-Y., \& Min, J. (2016). The profiles of creative potential and personality characteristics of adult professionals. Creativity Research Journal, 28(3), 298-309.

Liang, C.-T., Chia, T.-L., \& Liang, C. (2015). Effect of personality differences in shaping entrepreneurial intention. International Journal of Business and Social Science, 6(4.1), 166-176. 
Lin, N. (2002). Social Capital: A Theory of Social Structure and Action. Cambridge University Press.

Lin, W.-S., Hsu, Y., \& Liang, C. (2014). The mediator effects of conceiving imagination on academic performance of design students. International Journal of Technology and Design Education, 24(1), 73-89.

Liñán, F., \& Chen, Y. (2009). Development and cross-cultural application of a specific instrument to measure entrepreneurial intentions. Entrepreneurship Theory and Practice, 33(3), 593-617.

Liñán, F., \& Santos, F.J. (2007). Does social capital affect entrepreneurial intentions? International Advances in Economic Research, 13(4), 443-453.

Lorenz, G. (2008). The implementation of social capital features in social auditing procedures to secure community accountability of social enterprises in the third sector. Retrieved 15 March, 2017 from http:// base.socioeco.org/docs/social_audit_conscise-usti2008.pdf

Mair, J., \& Noboa, E. (2006). Social entrepreneurship: How intentions to create a social venture are formed. In J. Mair, J. Robinson, and K.N. Hockerts (Eds.), Social Entrepreneurship (pp. 121-135). Basingstoke, U.K.: Palgrave MacMillan.

Mander, Ü., Wiggering, H., \& Helming, K. (Eds.) (2007). Multifunctional land use: Meeting future demands for landscape goods and services. New York, NY: Springer.

Markham, T. (2012). The politics of journalistic creativity: Expressiveness, authenticity and de-authorization. Journalism Practice, 6(2), 187-200.

McManus, K. (April 30, 2015). Why journalists make great entrepreneurs. Retrieved October 9, 2016, from http://mediashift.org/2015/04/whyjournalists-make-great-entrepreneurs/

Nahapiet, J., \& Ghoshal, S. (1998). Social capital, intellectual capital, and the organizational advantage. Academy of Management Review, 23(2), 242-266.

Newman, N., Dutton, W.H. \& Blank, G. (2012). Social media in the changing ecology of news: The fourth and fifth estates in Britain. International Journal of Internet Science, 7(1), 6-22.

Partanen, J., Kristian, M., Westerlund, M., Rajala, R., \& Rajala, A. (2008). Social capital in the growth of science-and-technology-based SMEs. Industrial Marketing Management, 37(5), 513-522.

Pelchat, M.-C. (2005). Social entrepreneurship in Taiwan: Possibilities and challenges for empowerment. Paper presented at the $4^{\text {th }}$ ISTR Asia and Pacific Conference. November 16-18, Bangalore, India.

Pittaway, L., \& Cope, J. (2007). Entrepreneurship education: A systematic review of the evidence. International Small Business Journal, 25(5), 479-510.

Richards, I. (2013). Beyond city limits: Regional journalism and social capital. Journalism, 14(5), 627-642.

Runco, M.A., \& Jaeger, G. (2012). The standard definition of creativity. Creativity Research Journal, 24(1), 92-96. 
Shaw, E., \& Carter, S. (2007). Social entrepreneurship: Theoretical antecedents and empirical analysis of entrepreneurial processes and outcomes. Journal of Small Business and Enterprise Development, 14(3), 418-434.

Shaw, E., Lam, W., \& Carter, S. (2008). The role of entrepreneurial capital in building service reputation. The Service Industries Journal, 28(7), 899-917.

Simon, M., Houghton, S.M., \& Aquino, K. (2000). Cognitive biases, risk perception, and venture formation: How individuals decide to start companies. Journal of Business Venturing, 15(2), 113-134.

Siu, W.-S., \& Lo, E. S.-C. (2013). Cultural contingency in the cognitive model of entrepreneurial intention. Entrepreneurship Theory and Practice, 37(2), 147-173.

Smith, J. A. (2012). Journalism is becoming a form of social entrepreneurship. Stanford Social Innovation Review, 10(1), 23-25.

Stewart, W.H., \& Roth, P.L. (2004). Data quality affects meta-analytic conclusions: A response to Miner and Raju (2004). Concerning entrepreneurial risk propensity. Journal of Applied Psychology, 89(1), 14-21.

Storey, J., Salaman, G., \& Platman, K. (2005). Living with enterprise in an enterprise economy: Freelance and contract workers in the media. Human Relations, 58(8), 1033-1054.

Thompson, E.R. (2009). Individual entrepreneurial intent: Construct clarification and development of an internationally reliable metric. Entrepreneurship Theory and Practice, 33(3), 669-694.

Valenzuela, S., Park, N., \& Kee, K.F. (2009). Is there social capital in a social network site? Facebook use and college students' life satisfaction, trust, and participation. Journal of Computer-Mediated Communication, 14(4), 875-901.

Vitiello, D., \& Wolf-Powers, L. (2014). Growing food to grow cities? The potential of agriculture foreconomic and community development in the urban United States. Community Development Journal, 49(4), 508-523.

Wang, J.-H., Peng, L.-P., \& Liang, C. (2014). Developing and testing the psychological influence, rural practice, and entrepreneurial intention scales. Review of Agricultural Extension Science, 31, 72-95.

Williams, D. (2006). On and off the 'Net: Scales for social capital in an online era. Journal of Computer-Mediated Communication, 11(2), 593-628.

Yao, S.-N., Peng, L.-P., Lee, J.-L., \& Liang, C. (2016). Imagining rural practice. Business Creativity \& the Creative Economy, 2(1), 62-69.

Zampetakis, L.A. (2008). The role of creativity and proactivity on perceived entrepreneurial desirability. Thinking Skills and Creativity, 3(2), 154-162.

Zhang, L.-F. (2008). Revisiting the big six and the big five among Hong Kong university students. Educational Psychology, 28(1), 1-14.

Zhao, H., \& Seibert, S.E. (2006). The Big Five personality dimensions and entrepreneurial status: A meta-analytical review. Journal of Applied Psychology, 91(2), 259-271. 
Zhao, H., Seibert, S.E., \& Lumpkin, G.T. (2010). The relationship of personality to entrepreneurial intentions and performance: A meta-analytic review. Journal of Management, 36(2), 381-404.

\begin{abstract}
Abstrakt
Dziennikarze nieustannie staja przed różnymi wyzwaniami, a w dobie cyfrowej konwergencji czasem nie nadqżajqc za nowościami w obliczu zmieniajqcych się ekosystemów. Wielu dziennikarzy rozpoczęło współpracę ukierunkowanq na rozwój przedsiębiorstw społecznych zauważajqc podobieństwa w charakterystyce ich zawodu z przedsiębiorcami społecznymi, który przyczynia się do zmiany społecznej dzięki biznesowemu podejściu do problemów społecznych. Przedstawione w tekście badanie ma na celu poznanie intencji zakładania przedsiębiorstw społecznych przez byłych i obecnych dziennikarzy. W badaniu użyto kwestionariuszy badajqcych cechy osobowości, poziom kreatywności i kapitał społeczny. Wyniki badania pokazujq, że kreatywność oraz wysoki pomostowy kapitał społeczny majq istotne znaczenie dla 'społecznych' intencji przedsiębiorczych wśród dziennikarzy.
\end{abstract}

Słowa kluczowe: kreatywność, intencje przedsiębiorcze, cechy osobowości, kapitał społeczny, przedsiębiorstwo społeczne.

\title{
Biographical notes
}

Huei-Ching Liu is a senior reporter in Liann Yee Production Co., Ltd., TVBS TV Network, Taipei, Taiwan. She gained her master's degree in Graphic Arts and Communications at the National Taiwan Normal University. Huei-Ching is currently a part-time doctoral student in the Department of Bio-Industry Communication and Development at the National Taiwan University. Her research interests focus on: media convergence, communication education, multimedia communication, and entrepreneurship.

Ching Yin Ip is a doctoral student and research assistant in the Department of Bio-Industry Communication and Development, National Taiwan University, Taipei, Taiwan. He obtained his master's degree in Corporate Communication at the Chinese University of Hong Kong. His current research interests cover social capital, corporate communication, corporate social responsibility, and social entrepreneurship.

Chaoyun Liang is a Professor in the Department of Bio-Industry Communication and Development, National Taiwan University, Taipei, Taiwan. He gained his Ph.D. in the Instructional Systems Technology program at the Indiana University, USA. His current research interests focus on: imagination and creativity, entrepreneurship \& social enterprise, and agrirural communication \& marketing. 


\title{
Social Initiatives in Food Consumption and Distribution as Part of Sustainable Consumption and Sharing Economy
}

\section{Katarzyna Bachnik¹, Justyna Szumniak-Samolej}

\begin{abstract}
The aim of this paper is to extract and describe recent social initiatives in food consumption and distribution in Poland and indicate their characteristics related to sustainable consumption, sharing economy and collaborative consumption and to indicate the processes, mechanisms and future development options. Food is among areas that seem to adapt to those ideas more easily which means that individual consumers seem to see value in behaving in a more responsible way. In Poland, social awareness is rather limited and responsible behavior happens on a minor scale for the moment, but more international research shows the great potential of sharing economy. Food is being wasted therefore it constitutes a good ground for changing consumption habits. The paper presents four chosen social initiatives in Poland that refer to a sustainable consumption philosophy and collaborative consumption. Those mini case studies are backed by a thorough analysis of relevant literature, theme contents on websites, and results of secondary research studies dedicated to the issues discussed in the paper. Due to the qualitative character of the study, it shall be followed by more quantitative research to allow for more general insights and conclusions.

Keywords: sustainable consumption, sharing economy, collaborative economy, social initiatives, food industry.
\end{abstract}

\section{INTRODUCTION}

Food consumption is a subject linked with numerous problems and challenges of an ethical and environmental nature. It is also marked by many contrary phenomena and food philosophies. On the one hand billions of people all over the world starve or suffer from malnutrition - about one in nine people

1 Katarzyna Bachnik, Ph.D., Hult International Business School, 1355 Sansome Street, San Francisco, CA 94109, USA; e-mail: katarzyna.bachnik@faculty.hult.edu.

2 Justyna Szumniak Samolej, Ph.D., Department of Management Theory, Warsaw School of Economics, al. Niepodległości 162, 02-554 Warsaw, Poland; e-mail: justyna.szumniak@sgh.waw.pl. 
on earth do not have enough food to lead a healthy active life (World Food Programme, 2016) - while others waste or discard uneaten food - roughly one third of the food produced in the world for human consumption every year gets lost or wasted (Food and Agriculture Organization of the United Nations, 2016). Whilst the food that is widely offered is more and more modified, processed and polluted, there are increasing numbers of people who want to consume real and worth eating food - products which are healthy, organic, coming from a well-known source and unprocessed. Whereas some choose the comfort of fast food, others hold to a slow food philosophy celebrating the process of preparing and consuming meals as well as protecting traditional and local ways of food production. Food consumption has, therefore, a cultural meaning also. As Kniazeva and Venkatesh (2007, p. 432) conclude: "food values and habits function as key cultural expressions that are central to the processes by which people establish, maintain and reinforce their (sub) cultural, ethnic, and individual identities." Philosophies and trends connected with food consumption are constantly evolving, undergoing transformations due to other social phenomena. It seems the process is progressing in the age of net technology diffusion, particularly social media, since information reaches millions of users in real time and the distance between people has definitely lessened, allowing for cooperation on an unprecedented scale. Holt (2016) says that digital crowds are currently very efficient 'innovators of culture' as they can, successfully, push forward their ideas, trends or habits to other social groups.

For these reasons, the following paper bridges a literature gap by focusing on the sustainable consumption movement, sharing economy and collaborative consumption, showing interdependencies between them, and by presenting some up-to-date mechanisms in the context of food distribution and consumption in Poland. Such an approach is understudied in Poland at the moment. The aim of the paper is to extract and describe selected ventures of sustainable consumption, sharing economy and collaborative consumption in food consumption and distribution in Poland and to indicate the processes, mechanisms and future development options. The paper addresses these issues in trying to figure out:

- What are the goals of recent social initiatives in food consumption and distribution, referring to sustainable consumption and sharing economy in Poland?

- How are they organized and what are their ways of acting (in terms of main distinguishing features)?

- How (in which areas) they refer to sustainable consumption and sharing economy? 
The structure of the paper is as follows: firstly, the concept of sustainable consumption and sharing economy is introduced so as to build a theoretical framework for the study. It is followed by a methodology introduction of the tools and approaches selected for the research. Then four case studies are highlighted so as to give evidence for tangible mechanisms and business options for sustainable consumption, sharing economy and collaborative consumption. The analysis ends with conclusions.

\section{LITERATURE REVIEW}

\section{Sustainable consumption}

Sustainable consumption is an inseparable part of corporate social responsibility (CSR), as well as sustainable development, that may be defined as 'harmonious development, compatible with a fragile balance of a global ecosystem and not entailing economy overexploitation of raw materials, and moreover, uncontrolled side effects in a social and economic field' (Mróz, 2013, p. 171; Brundtland Report, 1987). Based on 'reasonable usage of consumption of goods and an attempt to preserve a global ecosystem balance in the name of responsibility for future generations and our planets destiny' (Mróz, 2013), its existence is conditioned by consumers who present much bigger responsibility and tremendous ecology consciousness. According to McDonald et al. (2012), these are individual consumers, not governments or enterprises, who have a key role to play in meeting the targets for reduced energy consumption, more sustainable waste management practices and lifestyles with fewer environmental consequences. The consumption undertaken by private accounts of households are as high as $30 \%-40 \%$ of the economy's environmental impact. Consumers who believe that their decisions can significantly affect environmental and social issues are more likely to behave sustainably (Antonetti \& Maklan, 2014). According to Greenpeace, this type of consumer regulates their consumption needs, taking higher values into consideration (Peborgh \& Odiseo Team, 2008, p. 129). They make more informed shopping decisions, trying to learn where the products come from, and how they will be disposed. They try to reduce the negative impact of their living on the environment by reducing their consumption or by discontinuing unnecessary purchases. They perceive shopping decisions as signs of their approval or protest against particular company operations. They have a sense that by showing a good example they can make other people follow their behavior.

An effective idea of sustainable consumption introduction is determined by such variables on the consumers' side as their personality, shopping habits 
and the structure of needs. If we consider personality, it is about innate drives, learned motives and experience of the individual, which also translate into a person's motivational dispositions arising from the interaction between biological drives and the social and physical environment (Evans, Jamal \& Foxall, 2009, p. 201). We may be more inclined to follow green regulations just because we feel it is the right thing to do, while others would require additional arguments before they comply. Habits also stem out of the experience from the trial-and-error process. We learn to perform behaviors that produce positive outcomes and avoid those that yield negative outcomes. Segregating waste might be an easy habit to form unless there is reinforcement, such as lower monthly fees for garbage collection or membership of a green community. What is more, learning about habits would give clues not only about the sole act of purchasing but also of consuming and disposing of the remnants. The structure of needs, on the other hand, sheds more light on motivation and prioritizing process (Schiffman, Kanuk \& Wisenblit, 2010, p. 107). In the modern world, most consumers seek products to simultaneously satisfy various types of needs. As a result, many brands try to deliver this value. If we consider the abundance of eco-food, it aims at satisfying hunger, building health condition and caring for the environment at the same time. As research shows, the motivations of sustainable consumption include purchasing ethical alternatives, recycling, reducing personal consumption, and saving energy (Antonetti \& Maklan, 2014).

Also, the fundamental point is that growing ecology consciousness gives rise to abt. 2/3 European Union consumers who are ready to buy products marked with eco labels (the so called 'green products'). (Mróz, 2007). What is more, the consumers who actively take up a more ecological and balanced lifestyle, easily identify with the slogan: 'We can really change the world by responsible and ethical consumption' (Rok, 2009). Following the sustainable consumption track is easier due to outside factors, in relation to consumers, such as using energy-efficient and material-saving production technologies, and eliminating harmful materials in production processes. Ecology solutions tend to be at the forefront. They are heading towards usage-limiting natural environmental resources.

In conclusion, the understanding of sustainable consumption adopted in this article coincides with Sheth, Sethia and Shanthi's (2011) proposal. According to the authors, sustainable consumption can be interpreted as 'mindful consumption' that is "guided and underpinned by a mindful mindset that reflects a conscious sense of caring toward self, community and nature."

Sustainable consumption in a food area may concern a different kind of attitudes and behavior. It includes i.a., conscious food products choice taking into consideration their origin so to select organic ones coming from 
local suppliers, produced in an ecological way and socially responsible, and putting attention to eco labelling. It also covers package usage reduction and choosing the ones which are ecological. However, sustainable food consumption means limiting consumption too - not buying food overload and food waste prevention.

From the main subject perspective in this paper, the research results, having been commissioned by the European Union, indicate that barely three product categories and services cause up to $70 \%$ of the detrimental effects on the natural environment (while making merely half of the overall consumer spending). These three categories are food products, transport and construction (Mróz, 2013, p.174). As Voget-Kleschin (2014) claims food consumption proves some tension between individual lifestyles and societal consequences of such lifestyles, but asking individuals to behave more sustainably is unnecessary. Early research conducted among Polish consumers proves that the idea of sustainable consumption is not much known (Dąbrowska \& Gutkowska, 2015). Sustainable consumption behavior can be seen on a minor scale and the behavioral intensity is differentiated by socio-demographic variables and by lifestyle qualities. However, market shortages in the 1980s taught Polish consumers the value of an exchange of goods and services with others, which might turn into a sustainable habit being part of collaborative consumption in the longer term. The US market, as a mature one, proves the potential of collaborative consumption: $19 \%$ of the total US adult population has engaged in a sharing economy transaction and of those consumers who have tried sharing economy, $72 \%$ declare that they could see themselves being a consumer in the sharing economy in the next two years (PwC, 2015).

\section{Sharing economy and collaborative consumption}

Adopting an approach that sustainable consumption aims at shaping such a demand and consumer behavior, on the one hand, to meet their demands and raise life quality, and on the other hand, at the same time, to regenerate environmental capital for future generations, grassroots initiatives appearance helps promote a responsible attitude and makes an ecology procedure possible. Concomitantly with limiting usage and wastage of materials, raw materials, energy and agriculture, one needs to acknowledge it as an enabler. On the grounds of it, one can justify the statement saying that sustainable consumption and sharing economy are strongly linked. It is especially true within the food industry. Food, money, goods, services, transportation, space are among six dimensions that absorb practices, norms and behavior typical for sharing economy easily (Morgan, 2014). 
Sharing economy, also named collaborative economy, seems to gain more momentum now and as such has the power to fuel sustainable consumption or take it to the next level. It embeds a distinctive mechanism of human and physical resources sharing, in order to achieve one's goal, but it is an access to demanded products, services or resources, instead of a traditional transfer of ownership, that defines the core of this trend. As Botsman (Collaborative Consumption, 2014) defines sharing economy: It is "an economy built on a series of networks of connected individuals and communities versus centralized institutions, transforming how we can produce, consume, finance, and learn." Owyang compares sharing economy to honeycombs arguing that both are quite resilient structures that "efficiently enable many individuals to access, share and grow resources among a common group" (Morgan, 2014).

It seems that people no longer need to possess items to feel satisfied (Bardhi \& Eckhardt, 2012). They can share spare capacity and reduce costs associated with ownership. Sharing economy can be described as a new model of production and consumption that assumes "the shared creation, production, distribution, trade and consumption of goods and services by different people and organizations" (Morgan, 2014). Sharing economy rests upon the assumption that people are willing to collaborate once they see some value from the collaboration. The transactions in the system do not take the traditional form of an exchange of product or service with money; they can take the form of access such as renting, lending, subscribing, reselling, swapping, donation.

What is more, according to Botsman and Rogers (2010) people engaged in sharing must conform to four behavioral rules and principles, which are the following:

- trust between strangers, which is a must to close the deal and facilitate the exchange;

- belief in the commons, which means believing that society can secure access to goods for as much of the public as possible;

- idling capacity, as the basic observation leads to the realization that some assets might be underused, and in effect solutions to change the picture are appreciated;

- a critical mass of followers and advocates build the socio-economic system and facilitate its functioning (Bachnik, 2016).

Also, the participants' motivation of sharing economy is vital to make their engagement long-lasting and sustainable. There are several benefits that might encourage participants to join the sharing economy movement, such as:

- an opportunity of using goods, services and "experiences" for prices lower than those offered by traditional firms;

- an opportunity of using goods without a requirement to buy or own them; 
- a source of additional earnings for contractors;

- a social dimension of a given type of consumption and production (i.e., meeting new people, companionship of others, the feeling of building a community);

- added value - new experiences, feelings, "atmosphere" (i.e., atmosphere of a private home vs. an anonymous hotel room) (Szumniak-Samolej, 2016).

For some people an important advantage of the psychological nature of participating in a sharing economy is the well-being resulting from a sense of being useful, undertaking good actions (for oneself and others), which for instance, make for building a community, supporting useful initiatives, protecting the environment, 'fighting with a system', and caring for alternative (not commercial) production methods. Some researchers argue that a stronger emotional connection with the customer might be a success factor (Straker \& Wrigley, 2015).

The trend indicates that consumers are more and more active, adopt an attitude definitely entrepreneurial, on the one hand, to meet their demands, while on the other hand behave responsibly and in compliance with ethical norms they believe. Entrance barriers to a great number of markets are limited to the minimum, as well as new possibilities generated by contemporary ICT let consumers conclude agreements, form communities and create new enterprises which, directly after recruiting a critical mass of supporters, transform into successfully prospering entrepreneurs.

Thus, as took place in the case of sustainable consumption and also regarding sharing economy, one can point to outside determinants conductive to the development of 'access over ownership' approach. These factors are of a social, economic and technological nature (Mróz, 2013; European Union, 2013). Consumer mindfulness comes into mind in the first place. It results from the experience connected with the course of the latest crisis 2008-2014, which made a great many consumers tighten their belts and have a look at their budget management more carefully, strictly linked to the decrease of consumer trust in the corporate world and to the drop in the purchasing power of consumers. The growth of environmental awareness and a rising significance of digitalization expressed by the fact that consumers have become cross-channel shoppers more often and a big part of shopping are online transactions; some of the products are of a digital character. Therefore, meeting demands is not equivalent to the necessity of possessing products. In effect, the potential of the sharing economy is significant, with annual growth exceeding $25 \%$.

In addition, sharing economy seems to undergo an evolution (The next wave, 2014). It was started by companies seeking to find an easy way to share 
goods. Online classified advertisements like Craigslist started to emerge as early as 1995, followed around 2008 by rentals of homes and apartments (like Airbnb), which introduced services into the sharing economy. From 2010 it has become a multi-faceted industry that touches on nearly every aspect of everyday life, covering not only goods and services but also expertise in the form of, e.g., the marketplace for learning and teaching online (Udemy Blog, 2014).

It also needs to be put straight that sharing economy is a system in which individuals, including start-ups, who can find in this scheme an idea for a business model and traditional firms, which can conform to the conditions of this system, can operate in concomitance with each other.

Sharing economy and collaborative consumption in terms of food is quite a broad issue. The most evident way is transferring and receiving food from others. However, sharing food may take place in numerous production stages and food stages. It can deal with cost sharing and work needed to either produce or sell, transport or a production process. (Buczynski, 2013, p. 150).

\section{RESEARCH METHODS}

The study was conducted in five steps. Firstly, to identify the fundamental themes of the research and the prevailing key issues, a literature review was conducted. In the second step identification of initiatives and their selection for case studies was completed. The purposive sampling technique was considered here. The selection criteria were as follows:

1) It was assumed to focus on social initiatives. Social initiatives were defined as social ventures representing "a new type of organization that aim to create sustainable social value, such as promoting the well-being of communities and their existence is based on developing solutions to tackle complex social problems" (Jokela \& Elo, 2015).

2) To become case studies, selected initiatives should meet the sharing economy criteria according to Botsman (Collaborative Consumption, 2014) who defined sharing economy as "an economy built on a series of networks of connected individuals and communities versus centralized institutions, transforming how we can produce, consume, finance, and learn." Networks of connected individuals and communities are perceived here as grassroots social initiatives - pioneered by individuals or groups of independent legal subjects, not by formal organizations (companies or non-governmental organizations).

3) To become case studies, selected initiatives should be coherent with the following understanding of sustainable consumption: it is a 'mindful consumption' that is 'guided and underpinned by a mindful mindset that 
reflects a conscious sense of caring toward self, community and nature' (Sheth et al., 2011).

4) It was assumed that selected initiatives shall relate to food consumption and distribution, and

5) They were to be established recently (2013-2016) in Poland.

The third step was about data collection. To build case studies, online desk research, including web pages and various social media, was completed. Fourthly, the descriptive research method was used to design four initiatives which would fit the above-mentioned selection criteria. The descriptive research method was selected as the one used to "determine, describe or identify what is" (Ethridge, 2004), which we understand as describing characteristics and various aspects of the phenomenon. Agreeing on the method allowed us to arrive at the goal of the paper which is to extract and describe recent social initiatives in food consumption and distribution in Poland and to indicate their characteristics related to sustainable consumption, sharing economy and collaborative consumption.

Finally, in the fifth step, we prepared a table to organize the insights and benchmark selected initiatives which led to conclusion formulation.

\section{ANALYSIS/STUDY}

\section{Food Cooperative Good}

Food Cooperative Good is one of several food cooperatives developing dynamically in Warsaw recently. The Cooperative has been functioning since July, 2013. Originally it was an informal group which used to organize mutual shopping of healthy and organic food from local farmers. Currently it is registered as non-profit, calling 'Warsaw cooperative initiative.' The Cooperative is formed by over 170 people of different ages and various backgrounds describing their activities, using such words: 'We care for building fair and based-on-trust relationships with those who deliver food to us. We create a community accomplishing a common goal - healthy and seasonal food access produced locally, excluding a big business and the chain of corporations' agents (Kooperatywa Dobrze, 2014a). Among many other motivations to work, the members of the cooperative stress increased access to healthy, fresh and seasonal food, promotion of local farms development, winning back the influence on their vicinity, learning to cooperate in a group, grassroots democracy and forming a practical alternative for supermarkets selling low quality food, and for expensive organic shops (Kooperatywa Dobrze, 2016). 
Anyone can join the Cooperative Good. To become a member one needs to support it financially and offer a required work load. The monthly fee is 25 zlotys and a minimum required work load is 3 hours a month. The work schedule is announced for the subsequent three months, and the members declare performing goals predicted in the schedule in advance. The Cooperative work includes goods transport, organizing promotional events, doing administrative work and activity in the shop owned by the Cooperative (Kooperatywa Dobrze, 2014b).

This is the shop which distinguishes the Cooperative Good among other Warsaw food cooperatives. The shop launched in August 2014, in the center of Warsaw and is the first cooperative food shop since 1989. You can buy there healthy, organic food produced by local farmers at fair prices, that is to say, lower than in regular shops with organic shops, and moreover, organic coffee, Fair Trade chocolate, organic oils, honey, dried fruit sold by weight, sugar and gluten-free sweets and organic cosmetics together with cleaning supplies (Słowik, 2016). The shop is also a venue to conduct both educational and integration activities.

The shop is open six days a week and serves anybody who wants to do shopping there. However, there is a difference in prices for members and nonmembers. The cooperative members are entitled to lower prices, covering the price cost (Kooperatywa Dobrze, 2016b).

The shop is owned and jointly managed by all members of the cooperative. From the perspective of the shop activities, the cooperative employs only five persons in the key posts. The shop activity is not orientated to profit, the generated turnover is solely allocated to the development of the shop, cooperative and organizing activities open to social-educational enterprises.

What is worth mentioning is that the shop start-up was subsidized with the use of crowdfunding mechanisms through the Polakpotrafi.pl platform. The project was supported by 208 persons who collectively donated 15307 zlotys, while the minimum sum declared by the project author amounted to 12000 zlotys (Polakpotrafi.pl, 2016a). As research suggests, crowdfunding might be a good method of funding innovation (Kozioł-Nadolna, 2016).

The shop met with such a warm reception that in July 2016, another shop was opened in Warsaw Muranów. This time it was decided that financing would be implemented on two tracks. The first stage was to issue coupons. In the framework of 'Trust Credit' actions the coupons, having been a kind of credit, were sold - the purchase of them meant borrowing money for a new shop start-up. After January 2016, it would be possible, in one of the two Cooperative shops, to exchange the coupons for goods. The second stage of financing was a renewed crowdfunding action on Polakpotrafi.pl portal. As a result, successfully, the initial amount of 17500 zlotys was exceeded 
and $20-690$ zlotys were collected. The project was backed by 274 persons (Polakpotrafi.pl, 2016b).

The cooperative activity is based on forming and motivating cooperating communities. That is why The Cooperative Good organizes regular meetings for its members and what is more, visits to cooperating farmers. Their profiles are also presented on the cooperative's website. Furthermore, running open and educational meetings, e.g. a cooperative congress, workshops devoted to child feeding, meetings with banana planters, workshops dedicated to organic cosmetics, lectures on common food economy, etc., Facebook is used for all communication with shop clients and those who are interested in the cooperative enterprise.

The Cooperative Good is a developing, grassroots movement of aware Warsaw residents, those who are eager to get back the control of food consumed by them as well as actively influencing the reality around them. As one can read on the cooperative's website: 'food cooperatives and other grassroots enterprises are the proof that operating in an economy domain can be based on cooperation and trust, taking into consideration work conditions and caring for nature. In Poland, the rising popularity of the cooperative shows that more and more of us are feeling like organizing ourselves in a new way. We need more practical alternatives which will make the world change gradually' (Kooperatywa Dobrze, 2016a).

\section{Foodsharing Warsaw}

Foodsharing is an initiative designed to reply to the fact of wasting and throwing away food still good to eat. Foodsharing is about sharing with other people the food which is still good enough to be consumed because we have an excessive amount that is likely to be wasted or discarded. Different kind of initiatives work in foodsharing areas i.a. in Germany, Austria, Switzerland, the United States or Great Britain (Braw, 2014). Since February 2016 foodsharing has also been present in Poland.

The first foodsharing center came up in the frame of the Foodsharing Warsaw initiative. The idea behind this initiative is trivially simple - in a special place equipped with a labeled refrigerator and a cupboard anybody can leave food and simultaneously take advantage of what is left. The point is to let everybody share with others - one can add something and help oneself. There can be both readymade and homemade food. In the former case, the food should be tightly closed and described in details. (Hansen, 2016). Not only individuals are encouraged to share food but also organizations (e.g., shops, restaurants, food producers) that can transfer a surplus of food to others instead of disposing it. 
Food quality in the centers is taken care of by special guardians, called food savers. Their task is to check products shelf life and keep the fridges and shelves clean.

Currently, in the framework of Foodsharing Warsaw, three centers are working. The first one is situated at The Psychology Department of Warsaw University, the second one is in Warsaw Jazdów, and the third one in Stół Powszechny - both the café and workshop space functioning by the Powszechny Theatre in Warsaw. This initiative is also supported by its profile on Facebook where one can forward news about the latest events and foodsharing initiatives, the ways to limit food waste, and what is more, building a community consisting of those people to whom the subject is close.

Recently, Foodsharing Torun and Foodsharing Cracow opened, again created by volunteers-social activists' grassroots initiatives.

\section{FEED Them Up}

FEED Them Up is a project evolved and set in motion in March 2016, by a group of students from Warsaw School of Economics. The project was meant for the Nationwide Olympiad 'Theory Released' directed at upper-middle students and pupils, and its aim is to develop participants' practical skills in the field of project management and inspiration for social activities (Zwolnieni z Teorii, 2016). The project was created as a response to a huge problem regarding food waste in Poland, in opposition to an enormous demand for food supply by charity institutions.

Since 2013, new regulations concerning food transfers have been in force in Poland, which mean that shops, restaurants and other kinds of eateries do not pay VAT on food transferred free of charge to public benefit organizations. Previously, only food producers benefited from tax reliefs, so for others, the VAT was a cost and therefore discarding food was more profitable. Despite legal conveniences introduced a few years earlier, due to a lack of knowledge, will or logistic difficulties, not many eateries and shops decided to transfer their food surplus systematically to the most deprived.

The idea of the FEED Them Up enterprise is to employ food surpluses discarded by shops and eateries every day and transferring them to public benefit organizations for charity. The food transferring procedure is simple. FEED Them Up works as an agent, a platform connecting places which want to transfer food and organizations helping people in need.

At the beginning of the cooperation public benefit organizations inform the project representatives about a rough food amount, the sort of food (unprocessed/processed/ready meals) and a frequency the food is to be delivered (every day/ a few times a week/once a month/only after events, etc.). On this basis, a suitable place or gastronomic places are chosen to 
transfer food to a given organization caring for those who need help (Feed Them Up, 2016).

Transport responsibility, most often, is on the side of charity organizations. However, if it is troublesome, FEED Them Up is trying to contact them with the nearest gastronomic place so that the organizations' employees or their persons in charge may take the food without the necessity of using transport or select the place having transport at its disposal.

As far as donors are concerned, all gastronomic places offering food to their customers are taken into consideration, like restaurants, coffee-houses, short-order bars specializing in dairy products, bakeries, confectioner's, also hotels, small catering firms and shops. Food from gastronomic places is transferred in a free donation form. Correspondingly to public benefit organizations, at the very beginning, gastronomic places inform FEED Them Up of an indicative amount, the kind of food and frequency of transfer. The centers are selected on this basis. The conditions of donation can undergo changes at any moment of the cooperation (Feed Them Up, 2016).

The advantage of FEED Them Up cooperation with food-outlets certainly includes satisfaction at helping the needy and limiting food waste, and additionally food leftovers recycling cost-cutting. Moreover, it supports a supplementary promotion of the places, on the project social networking sites (Facebook, Instagram, YouTube), on the website, as well as ranking in media (interview arrangements, recording of promotional materials in the gastronomic places). Also, every place receives a sticker saying: 'No food waste here,' that lets the place differentiate itself from others in respect of food care (Feed Them Up, 2016).

The FEED Them Up team works basically in Warsaw. However, inhabitants of other cities make contact with it (Gdańsk, Poznań, Wrocław, Łomża or Białystok). They want to continue this initiative in their cities. Obviously they have got such a possibility, and the FEED Them Up team shares its knowledge with them and hands over indispensable documents and promotional materials, and if necessary, helps to solve difficulties.

\section{Café Fińska}

Café Fińska is an interesting example of a café - a project which was created as an artistic happening for the Zone Fresh Competition in the framework of The Grolsch ArtBoom Visual Arts Festival in 2013, presenting art in a public space of Cracow. The aim of Café Fińska was to create a meeting place for closer and less known neighbors. According to its creators, it was a reply to the specific demands of a local community. Although there are quite a few attractive cafes, restaurants and entertainment venues making unrepeatable magic local color, still the places are run traditionally, basing on economic 
calculation. However, there are not enough venues 'open to people', overstepping social divisions which engage local initiatives and their dynamic is formed by participants. The creators expected Café Fińska would fulfill the niche (Café Fińska, 2016).

For the need of the café, some space in a small tenement house was adapted. The place facilities were successfully donated. Café Fińska stands for a place open to everybody - neighbors, occasional pedestrians or tourists. The fundamental difference between this café and other Cracow places was a cash-free exchange. It meant one could have some coffee or tea but paying not with money as a means of payment, but with something the guest wished to give in return - e.g., a drawing, an interesting story, some help, a smile or drawing some pictures on a paper tablecloth. The idea was to arrange a meeting place free of financial barriers for surrounding inhabitants. The place in which a sense of community and responsibility for this site is formed. A meal and coffee were to be only a pretext for a conversation and chat. Guests' visits were made more attractive by variable activities such as board games, chess or guitar evening sessions. Each Friday varied events were organized, like concerts, exhibitions, performances, workshops (Café Fińska, 2016). Café Fińska was also open to its guests' proposals as 'the place created by people for people of every age, full of positive energy and diversities' (Polakpotrafi.pl, 2016c).

According to the creators' assumption, the Café Fińska project was supposed to function during two festival weeks. Since it met with an extremely warm welcome on the part of Cracow inhabitants, funds were successfully donated (sponsors, prizes, crowdfunding fund-raising) and prolonged its 'life.' Ultimately, in its initial place, the café worked in 2013-2015. After this time, and due to commercial rent hikes, a new venue was necessary, and at the moment, the café's activity is suspended.

\section{DISCUSSION AND CONCLUSIONS}

Buczyński (2013, p. 19) says sharing economy can reinvent our understanding of what a good citizen is. Collaborative consumption questions a previous approach to professional success, personal wealth and the sense of being an active community member which was based on money and possession of material goods. Sharing allows the creation of a new definition of value which is far from financial motivation. The reason to engage in social initiatives assumes the sharing component is mainly about increasing resource efficiency and enriching one's own and other people's lives. It is more about relationships than tasks undertaken to satisfy psychological needs. Sustainable 
consumption provides a similar effect. It supports citizenship attitude and is in favor of redefining a successful concept in professional and private dimensions of life. The motivation to commit to the greater good, personified with tangible initiatives, drives individuals and organizations to adopt socially responsible norms of behavior and to engage actively in the improvement of natural environment quality and of life quality of communities. That is why the two concepts make for a creative quest of ideas and undertaking (often grassroots ones) social and business actions based on their assumptions. For the sake of the paper, the selection of proper social initiatives was crucial so as to shed more light on the processes, mechanisms and future development options of these ventures. Table 1 . summarizes the main findings and allows for comparisons.

Table 1. Summary of main characteristics of selected social initiatives in food consumption and distribution in Poland referring to sustainable consumption and sharing economy

\begin{tabular}{|c|c|c|c|c|}
\hline & $\begin{array}{l}\text { Food Cooperative } \\
\text { Good }\end{array}$ & $\begin{array}{l}\text { Foodsharing } \\
\text { Warsaw }\end{array}$ & FEED Them Up & Café Fińska \\
\hline Creation date & 2013 & 2016 & 2016 & 2013 \\
\hline 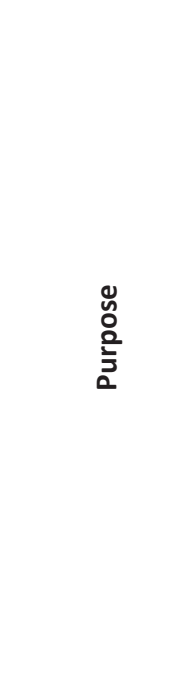 & $\begin{array}{l}\text { To create } \\
\text { a community } \\
\text { accomplishing } \\
\text { a common goal } \\
\text { - healthy and } \\
\text { seasonal food } \\
\text { access produced } \\
\text { locally, excluding } \\
\text { a big business } \\
\text { and the chain } \\
\text { of corporations' } \\
\text { agents }\end{array}$ & $\begin{array}{l}\text { To enable sharing } \\
\text { food with other } \\
\text { people to avoid } \\
\text { wasting and } \\
\text { throwing away } \\
\text { food still good } \\
\text { to eat }\end{array}$ & $\begin{array}{l}\text { In respond to } \\
\text { a massive problem } \\
\text { regarding food } \\
\text { waste in Poland, } \\
\text { in opposition to } \\
\text { an enormous } \\
\text { demand for food } \\
\text { supply by charity } \\
\text { institutions }\end{array}$ & $\begin{array}{l}\text { To arrange } \\
\text { a meeting place } \\
\text { free of financial } \\
\text { barriers for } \\
\text { surrounding } \\
\text { inhabitants. } \\
\text { To create a venue } \\
\text { 'open to people' } \\
\text { and overstepping } \\
\text { social divisions. } \\
\text { To engage } \\
\text { local initiatives } \\
\text { and encourage } \\
\text { "guests" to } \\
\text { form a sense of } \\
\text { community and } \\
\text { feel responsibility } \\
\text { for the site. }\end{array}$ \\
\hline 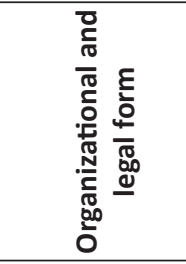 & $\begin{array}{l}\text { Originally it was } \\
\text { an informal group. } \\
\text { Currently it is } \\
\text { registered as non- } \\
\text { profit. }\end{array}$ & $\begin{array}{l}\text { Grassroots } \\
\text { initiative } \\
\text { undertaken by } \\
\text { volunteers-social } \\
\text { activists }\end{array}$ & $\begin{array}{l}\text { Project initially } \\
\text { set by a group of } \\
\text { students }\end{array}$ & $\begin{array}{l}\text { Project initially } \\
\text { created as an } \\
\text { artistic two-week } \\
\text { happening. Then, } \\
\text { prolonged thanks } \\
\text { to successful } \\
\text { fund-raising. }\end{array}$ \\
\hline
\end{tabular}




\begin{tabular}{|c|c|c|c|c|}
\hline & $\begin{array}{l}\text { Food Cooperative } \\
\text { Good }\end{array}$ & $\begin{array}{l}\text { Foodsharing } \\
\text { Warsaw }\end{array}$ & FEED Them Up & Café Fińska \\
\hline 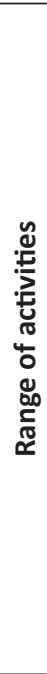 & $\begin{array}{l}\text { Organizing } \\
\text { mutual shopping } \\
\text { of healthy and } \\
\text { organic food from } \\
\text { local farmers } \\
\text { Running } \\
\text { a cooperative } \\
\text { food shop } \\
\text { Conducting } \\
\text { educational } \\
\text { and integration } \\
\text { activities }\end{array}$ & $\begin{array}{l}\text { Setting up and } \\
\text { caring for special } \\
\text { places equipped } \\
\text { with a labeled } \\
\text { refrigerator and } \\
\text { a cupboard where } \\
\text { anybody can } \\
\text { leave food and } \\
\text { simultaneously } \\
\text { take advantage of } \\
\text { what is left } \\
\text { Building } \\
\text { a community, } \\
\text { sharing } \\
\text { knowledge and } \\
\text { helping to set up } \\
\text { similar initiatives } \\
\text { in other cities }\end{array}$ & $\begin{array}{l}\text { Helping to employ } \\
\text { food surpluses } \\
\text { discarded by } \\
\text { shops and eateries } \\
\text { every day and } \\
\text { transferring them } \\
\text { to public benefit } \\
\text { organizations for } \\
\text { charity }\end{array}$ & $\begin{array}{l}\text { Running a café } \\
\text { offering drinks } \\
\text { and meals } \\
\text { Organizing, } \\
\text { concerts, } \\
\text { exhibitions, } \\
\text { performances, } \\
\text { workshops, etc. }\end{array}$ \\
\hline 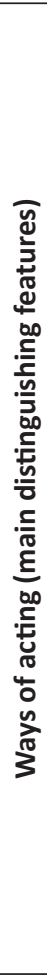 & $\begin{array}{l}\text { A food } \\
\text { cooperative } \\
\text { serving } \\
\text { cooperative's } \\
\text { members } \\
\text { Anyone can } \\
\text { join (to become } \\
\text { a member one } \\
\text { needs to support } \\
\text { it financially and } \\
\text { offer a required } \\
\text { work load) } \\
\text { The cooperative } \\
\text { shop is owned and } \\
\text { jointly managed } \\
\text { by all members of } \\
\text { the cooperative } \\
\text { The shop } \\
\text { serves anybody } \\
\text { who wants to } \\
\text { do shopping } \\
\text { there (there } \\
\text { is a difference } \\
\text { in prices for } \\
\text { members and } \\
\text { non- members }\end{array}$ & $\begin{array}{l}\text { Volunteers (called } \\
\text { food savers) take } \\
\text { after food quality } \\
\text { in the centers } \\
\text { Building and } \\
\text { supporting } \\
\text { on Facebook } \\
\text { a community } \\
\text { consisting of } \\
\text { people to whom } \\
\text { the subject } \\
\text { is close (e.g., } \\
\text { news about the } \\
\text { latest events } \\
\text { and foodsharing } \\
\text { initiatives, the } \\
\text { ways how to limit } \\
\text { food waste) }\end{array}$ & $\begin{array}{l}\text { FEED Them Up } \\
\text { works as an } \\
\text { agent, a platform } \\
\text { connecting places } \\
\text { which want to } \\
\text { transfer food and } \\
\text { organizations } \\
\text { helping people in } \\
\text { need. } \\
\text { Sharing } \\
\text { knowledge and } \\
\text { helping to set up } \\
\text { similar initiatives } \\
\text { in other cities }\end{array}$ & $\begin{array}{l}\text { A cash-free } \\
\text { exchange (not } \\
\text { with money } \\
\text { as a means of } \\
\text { payment, but with } \\
\text { something the } \\
\text { guest wished to } \\
\text { give in return - } \\
\text { e.g.,, a drawing, } \\
\text { an interesting } \\
\text { story, some help, } \\
\text { a smile, etc.) } \\
\text { Building } \\
\text { a community of } \\
\text { people who are } \\
\text { engaged and } \\
\text { responsible for } \\
\text { the venue. }\end{array}$ \\
\hline
\end{tabular}




\begin{tabular}{|c|c|c|c|c|}
\hline & $\begin{array}{l}\text { Food Cooperative } \\
\text { Good }\end{array}$ & $\begin{array}{l}\text { Foodsharing } \\
\text { Warsaw }\end{array}$ & FEED Them Up & Café Fińska \\
\hline & $\begin{array}{l}\text { The shop activity } \\
\text { is not orientated } \\
\text { to profit; the } \\
\text { generated } \\
\text { turnover is solely } \\
\text { allocated to the } \\
\text { development } \\
\text { of the shop, } \\
\text { cooperative and } \\
\text { organizing social } \\
\text { and educational } \\
\text { activities }\end{array}$ & & & \\
\hline 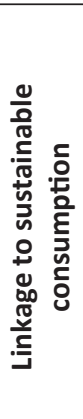 & $\begin{array}{l}\text { Healthy and } \\
\text { seasonal food } \\
\text { produced locally } \\
\text { Taking into } \\
\text { consideration } \\
\text { work conditions } \\
\text { Caring for nature } \\
\text { Motivation to } \\
\text { commit to the } \\
\text { greater good }\end{array}$ & $\begin{array}{l}\text { Enabling and } \\
\text { promoting } \\
\text { responsible and } \\
\text { conscious food } \\
\text { consumption } \\
\text { Reducing food } \\
\text { waste } \\
\text { Motivation to } \\
\text { commit to the } \\
\text { greater good }\end{array}$ & $\begin{array}{l}\text { Limiting food } \\
\text { waste by } \\
\text { gastronomic } \\
\text { places } \\
\text { Helping charities } \\
\text { (and people in } \\
\text { need) } \\
\text { Motivation to } \\
\text { commit to the } \\
\text { greater good }\end{array}$ & $\begin{array}{l}\text { Openness to } \\
\text { people and } \\
\text { overstepping } \\
\text { social divisions } \\
\text { Forming a sense } \\
\text { of responsibility } \\
\text { for the site among } \\
\text { visitors } \\
\text { Motivation to } \\
\text { commit to the } \\
\text { greater good }\end{array}$ \\
\hline 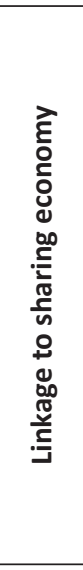 & $\begin{array}{l}\text { Cooperation, } \\
\text { trust, lack } \\
\text { of financial } \\
\text { motivation, work } \\
\text { done by members } \\
\text { to enrich their } \\
\text { own and other } \\
\text { people's lives }\end{array}$ & $\begin{array}{l}\text { Sharing food with } \\
\text { other people (for } \\
\text { free) } \\
\text { Sharing } \\
\text { knowledge } \\
\text { Work done by } \\
\text { volunteers to } \\
\text { increase resource } \\
\text { efficiency to } \\
\text { enrich their } \\
\text { own and other } \\
\text { people's lives }\end{array}$ & $\begin{array}{l}\text { Organizational } \\
\text { model in the form } \\
\text { of a platform } \\
\text { Sharing food with } \\
\text { other people (for } \\
\text { free) } \\
\text { Sharing } \\
\text { knowledge } \\
\text { Work done by } \\
\text { members to } \\
\text { increase resource } \\
\text { efficiency to } \\
\text { enrich their } \\
\text { own and other } \\
\text { people's lives }\end{array}$ & $\begin{array}{l}\text { A cash-free } \\
\text { exchange } \\
\text { Community } \\
\text { building } \\
\text { Community } \\
\text { members' } \\
\text { engagement } \\
\text { to enrich their } \\
\text { own and other } \\
\text { people's lives }\end{array}$ \\
\hline
\end{tabular}

Group shopping, the cooperative shop, work of every member for the association, cooperation based on trust, organic food, a desire for a local market and community development, offered by the Food Cooperative Good, show important aspects of the cooperative activity interacting with two trends, which are the subject of this paper. Facing everlasting promotions and widespread access to consumption goods, for many consumption community members, the effort to share food surplus with others is 
incomprehensible. This is not the case with Foodsharing Warsaw and FEED Them Up. These foodsharing believers work in the name of such values as food waste limiting or willingness to share with those who are in need. It seems to be peculiar organic work, producing small effects when it is smallscale. However, it can change a lot via education, raising social consciousness, and making solutions from this area more accessible and embedding. Apart from foodsharing support, FEED Them Up illustrates a common approach to participation in sharing economy through creating platforms. As with Uber, Blablacar, or Airbnb, FEED Them Up is a virtual 'meeting venue' - the service which connects service providers with those who want to take advantage of them. Although the trend of foodsharing is less booming in Poland than in the US and Germany, it provides a high sense of social and environmental responsibility of those who are actively engaged. Its progress in coming years will not only be a specific image of a sharing economy condition, but also pro-social and pro-ecology citizenships attitudes, particularly in an individual dimension, on a small scale, just as two illustrations from the Polish market show. In the spirit of sharing economy and sustainable consumption approach, Café Fińska is an alternative example to setting up cafes where food, its price, service quality or even the interior and 'climate' are not taken into consideration. There is something more important about it - a common property feeling and mutual responsibility for the place, building a common property and taking part in its functioning.

What is essential is that the initiatives discussed make active use of social media (e.g., crowdfunding, Facebook profile). The new media is a communication and promotion system, moreover, a cooperation platform for initiatives undertaken in the spirit of sustainable consumption and sharing economy. They make it possible to share in new ways, on a scale unavailable earlier. They ease and encourage participants to try group grassroots initiatives.

It needs to be underlined that all the described social initiatives came into existence as grassroots initiatives - originated from individuals or small groups. One of them (Food Cooperative Good), in the process of market development has changed its legal form and transformed into a formal organization (association) and another one (Café Fińska) due to commercial rent pressures is being suspended for the moment. It shows entrepreneurial spirit and the tangible need to throw into practice some values unifying more than just a few individuals. The pretty fast development of the ventures also indicates that their business models resonate well in the communities and may lead to the creation of follow-up businesses, set upon similar qualities rooted in sustainable consumption and sharing economy. Each sampling also shows a different organizational model, which provides evidence of how many different forms of operations are viable in order to adopt sustainability 
consumption and collaborative consumption notion in food consumption and distribution. Such flexibility may increase business viability for entrepreneurs.

The analyzed initiatives differ a lot in the range of undertaken activities, ways of acting and even in ways of relating to sharing economy and sustainable consumption notions. Nonetheless all of them meet the adopted study criteria of qualification to initiatives referring to sustainable consumption and sharing economy in food consumption and distribution. The biggest concern here is the sustainability of social initiatives undertaken in the food consumption and distribution sector. For the moment, being new and attractive, they sustain easily, however it is still unknown whether responsible consumption behaviors will be adopted by communities in the longer term. To verify perceptions and behavioral adoptions a more quantitative study, backed by in-depth interviews, shall be undertaken next. Its findings would also allow for more general insights and conclusions.

\section{References}

Anroinetti, P., \& Maklan S. (2014). Feelings that make a difference: How guilt and pride convince consumers of the effectiveness of sustainable consumption choices. Journal of Business Ethics, 124, 117-134.

Bachnik, K. (2016). Sustainable consumption through the sharing economy. Research Papers of Wroctaw University of Economics, 423, 35-44.

Bachnik, K. (2016). Zrównoważony rozwój a małe i średnie przedsiębiorstwa. In A. Skowronek-Mielczarek (Ed.), Zarzqdzanie małymi $i$ średnimi przedsiębiorstwami w warunkach zrównoważonego rozwoju (pp. 41-65). Warsaw, Poland: Difin.

Bardhi, F., \& Eckhardt, G. (2012). Access based consumption: The case of car sharing. Journal of Consumer Research, 39(4), 881.

Botsman, R. (2013). The sharing economy lacks a shared definition. Retrieved from http://www.collaborativeconsumption.com/2013/11/22/thesharing-economy-lacks-a-shared-definition

Botsman, R., \& Rogers, R. (2010). What's mine is yours: The rise of collaborative consumption. New York, NY: HarperCollins.

Braw, E. (2014, May). Free lunch, anyone? Foodsharing sites and apps stop leftovers going to waste. The Guardian. Retrieved from https://www. theguardian.com/sustainable-business/free-food-sharing-leftoverssurplus-local-popular

Brundtland Report (Our Common Future). (1987). United Nations World Commission on Environment and Development (WCED). Oxford, England: Oxford University Press.

Buczynski, B. (2013). Sharing is good. How to save money, time and resources through collaborative consumption. Gabriola Island, Canada: New Society Publishers. 
Café Fińska. (2016). Retrieved from http://cafefinska.wix.com/ cafefinska\#!about/c1c32

Dąbrowska, A., \& Gutkowska, K. (2015). Collaborative consumption as a new trend of sustainable consumption. Oeconomia, 14(2), 39-49.

European Union. (2013, September). Business Innovation Observatory. The sharing economy. Accessibility based business models for peerto-peer markets. Retrieved from http://ec.europa.eu/DocsRoom/ documents/13413/attachments/2/translations?locale=ro

Ethridge, D. E. (2004). Research Methodology in Applied Economics. Ames, IA: Blackwell Publishing.

Evans, M., Jamal, A., \& Foxall, G. (2009). Consumer behavior ( $2^{\text {nd }}$ ed.). West Sussex, England: Wiley.

Feed Them Up. (2016). Retrieved from http://feedthemup.com/o-projekcie

Food and Agriculture Organization of the United Nations. (2016). SAVE FOOD: Global Initiative on Food Loss and Waste Reduction. Retrieved from http:// www.fao.org/save-food/resources/keyfindings/en

Hansen, K. (2016, May). Foodsharing, czyli jedz, dziel się i kochaj! [video]. Newsweek. Retrieved from http://www.newsweek.pl/ styl-zycia/foodsharing-w-warszawie-stanela-pierwsza-w-polscejadlodzielnia,artykuly,385427,1.html

Holt, D. (2016, March). Branding in the age of social media. Harvard Business Review, Retrieved from https://hbr.org/2016/03/branding-in-the-age-ofsocial-media

Jokela, P., \& Elo, M. (2015). Developing innovative business models in social ventures. Journal of Entrepreneurship, Management and Innovation, 11(1), 103-118.

Kniazeva, M., \& Venkatesh, A. (2007). Food for thought: a study of food consumption in postmodern US culture. Journal of Consumer Behaviour, 6(6), 419-435.

Kooperatywa Dobrze. (2014a). Retrieved from http://www.dobrze.waw.pl/onas/

Kooperatywa Dobrze. (2014b). Retrieved from https://docs.google.com/file/d/ OBz2ifoflohOzSTJZQjNTcON4Z1pKMjJYQkpuRIZHbUxuaVJN/edit

Kooperatywa Dobrze. (2016a). Retrieved from http://www.dobrze.waw.pl/dlamediow

Kooperatywa Dobrze. (2016b). Retrieved from http://www.dobrze.waw.pl/onas/dolacz-do-nas (accessed 25.06.2016)

Kozioł-Nadolna, K. (2016). Funding innovation in Poland through crowdfunding. Journal of Entrepreneurship, Management and Innovation, 12(3), 7-29.

McDonald, S., Oates, C.J., Alevizou, P.J., Young, C.W., \& Hwang, K. (2012). Individual strategies for sustainable consumption. Journal of Marketing Management, 28(3-4), 445-468.

Möhlmann, M. (2015). Collaborative consumption: determinants of satisfaction and the likelihood of using a sharing economy option again. Journal of Consumer Behaviour, 14, 193-207. 
Morgan, J. (2014). Why the collaborative economy is changing everything. Forbes. Retrieved from http://www.forbes.com/sites/jacobmorgan/2014/10/16/ why-the-collaborative-economy-is-changing-everything

Mróz, B. (2007). Nowe trendy w konsumpcji a koncepcja społecznej odpowiedzialności biznesu: perspektywa europejska. In A. Dąbrowska, \& M. Janoś-Kresło (Eds.), Konsument na rynku europejskim, Warsaw, Poland: IBRKK.

Mróz, B. (2013). Konsument w globalnej gospodarce. Trzy perspektywy, Warsaw, Poland: Of. Wyd. SGH.

Panato Café. (2016). Retrieved from http://panato.org/panato-cafe

Peborgh, E., Odiseo Team. (2008). Sustainability 2.0. Buenos Aires.

Polakpotrafi.pl. (2016a). Retrieved from http://polakpotrafi.pl/projekt/sklepkooperatywy

Polakpotrafi.pl. (2016b). Retrieved from https://polakpotrafi.pl/projekt/drugisklep-kooperatywy-dobrze

Polakpotrafi.pl. (2016c). Retrieved from https://polakpotrafi.pl/projekt/cafejozefinska

PwC. (2015, April). The sharing economy. Consumer Intelligence Series. Retrieved from http://www.pwc.com/us/en/industry/entertainmentmedia/publications/consumer-intelligence-series/sharing-economy.html

Schiffman, L.G., Kanuk, L.L., \& Wisenblit, J. (2010). Consumer behaviour (10 ed). Upper Saddle River, NJ: Pearson Prentice Hall.

Sheth, J.N., Sethia, N.K., \& Shanthi, S. (2011). Mindful consumption: A customercentric approach to sustainability. Journal of the Academy of Marketing Science, 39, 21-39.

Słowik, K. (2016, July). Kooperatywa Dobrze otworzyła drugi sklep na Muranowie. Wyborcza. Retrieved from http://warszawa.wyborcza.pl/war szawa/1,34862,20384552,kooperatywa-dobrze-otworzyla-drugi-sklep-namuranowie.html?disableRedirects=true

Straker, K., \& Wrigley, C. (2015). The role of emotion in product, service and business model design. Journal of Entrepreneurship, Management and Innovation, 11(1), 11-28.

Strutyńska, J. (2014, September). Panato Cafe - płacisz za czas. Retrieved from http://www.wroclaw.pl/panato-cafe-placisz-za-czas

Szumniak-Samolej, J. (2016). Changes in the business environment. Research Papers of Wrocław University of Economics, 423, 122-137.

Szutowski, D., \& Ratajczak, P. (2016). The relations between CSR and Innovation. Model approach. Journal of Entrepreneurship, Management and Innovation, 12(2), 77-94.

Udemy. (2014). The next wave of the sharing economy [Blog post]. Retrieved from https://blog.udemy.com/the-next-wave-of-the-sharing-economy

Voget-Kleschin, L. (2015). Reasoning claims for more sustainable food consumption: A capabilities perspective. Journal of Agricultural and Environmental Ethics, 28, 455-477. 
World Food Programme. (2016). Hunger statistics. Retrieved from https:// www.wfp.org/hunger/stats

Ziferblat. (2016). Retrieved from http://www.ziferblat.co.uk

Zwiększenie konkurencyjności regionów poprzez społeczną odpowiedzialność biznesu (CSR) [Training materials]. (2012). Warsaw, Poland: PARP.

Zwolnieni z Teorii. (2016). Retrieved from http://www.zwolnienizteorii.pl/ about

\begin{abstract}
Abstrakt
Celem artykułu jest opisanie ostatnich inicjatyw społecznych w obszarze konsumpcji i dystrybucji żywności w Polsce i wskazanie ich cech zwiqzanych ze zrównoważonq konsumpcjq, ekonomiq współdzielenia oraz konsumpcjq współpracujqcq. Dodatkowym celem jest także wskazanie procesów, mechanizmów i przyszłych ścieżek rozwoju dla tego typu inicjatyw. Żywność to obszar, w którym implementacja wyżej wymienionych zjawisk wydaje się łatwiejsza, gdyż konsumenci dostrzegaja znaczenie swoich odpowiedzialnych wyborów. Jednak $w$ Polsce, świadomość społeczna $w$ tym zakresie jest raczej ograniczona, a zachowania odpowiedzialne występuja na małq skalę. Natomiast badania międzynarodowe wskazuja na duży potencjał gospodarki współdzielenia, także w obszarze żywności. Marnotrawstwo żywności jest dobrym punktem wyjścia do zmiany nawyków konsumpcyjnych. $W$ artykule przedstawiono cztery wybrane inicjatywy społeczne z Polski, które realizujq filozofię zrównoważonej i współpracujqcej konsumpcji. Z uwagi na jakościowy charakter studium, następnym etapem będq badania ilościowe pozwalajq̨ce na wysunięcie bardziej generalnych wniosków.
\end{abstract}

Słowa kluczowe: zrównoważona konsumpcja, ekonomia współdzielenia, ekonomia współpracujqca, inicjatywy społeczne, przemysł spożywczy.

\title{
Biographical notes
}

Katarzyna Bachnik, Ph.D., is an expert with 10-year experience in management, innovation and design thinking, international marketing, corporate social responsibility and social media. She has worked as a lecturer, a trainer and an editor and she is an author of several publications and expertise papers in the aforementioned areas. Affiliated at Institute of Management, Warsaw School of Economics, she has been granted several international scientific scholarships.

Justyna Szumniak-Samolej, Ph.D., is an Assistant Professor at Department of Management Theory, Warsaw School of Economics, Poland. Her key research areas are corporate social responsibility, social media and new business models. She participated in several research projects primarily focused on social corporate responsibility in the age of digital networked technologies. Her corporate social responsibility academic publications include books, refereed journal articles, book chapters and refereed conference papers. 


\section{Book Review}

\section{Title: Social Enterprise Model}

\section{Author: Małgorzata Halszka-Kurleto (Ph.D.); Difin (Polish publisher); 2016.}

The book consists of an introduction, four substantive chapters, a summary, and references. In the introduction, the author outlines her research problem which is aimed at the recognition of the most effective business models for social enterprise (SE). Throughout this recognition, the author aims to identify a social enterprise model for the Polish context and believes that this aim can increase the effectiveness of social enterprises in a competitive environment. The way these aims are formulated encompasses both theoretical and practical issues, which can be considered as particularly beneficial for the field of management research.

The first chapter includes a theoretical basis for social enterprise. Here, the author overviews the existing literature (from Australian, British and American contexts) but also refers to the domestic literature on the SE subject. The very core of social enterprise is adequately framed through pointing out that this is an enterprise that mainly pursues social aims, and reinvests generated profits to achieve these social aims, which in the end does not increase shareholders' incomes. In the next part of the book, the social enterprise construct evolution is presented, and the author uses here a system approach here, as well as providing comparative research between social and commercial enterprise (see table 5). As part of this research, the author outlines the main characteristics of a legal framework for social enterprise in British, American, Australian, Polish and European Union contexts. This is complemented by the provision of features of a social enterprise environment and SE commercialization process. 
What should be acknowledged as a particularly valuable achievement in Chapter 1 is a clear formulation of definition and attributes of a theoretical social enterprise model. The essence of social enterprise is the realization of social mission and achievement of related social goals thanks to received revenues and other streams from SE activity as well as donors. In the discussed theoretical model of social enterprise, the author includes social goals, moderating variable, outcome variable, particular social enterprise attributes, structure, innovation, as well as economic goals (Figure 4).

In the next chapter, the author considers how different models: business, processual, marketing and financial support; can be applied in designing the model for a social enterprise. This model outlines how: a) SE operates in the market, b) SE designs customer and beneficiary relationships, c) SE generates surplus from business activity, and d) SE captures the value offered to customers and beneficiaries. In the model, the following components are included: key partners, key resources and key relationships with clients (and beneficiaries). The driving forces for social enterprise are individual social entrepreneur features, human resources, and innovations. Among the innovations process, product and organizational innovations deserve particular emphasis. For the purpose of her research, the author proposes eight business models: fundraising-entrepreneurial, intermediary, support, complex, philanthropy, and patented.

The theoretical research presented in chapter two is very clear. Among the weaknesses of this effort, the application of Business Model Canvas (BMC) proposed by A. Osterwalder and Y. Pigneur without any earlier critical discussion should be highlighted.

BMC is characterized by too many components. The argumentation for this view is as follows:

- Customer segments, customer relationships, value proposition are, actually, one component of a business model that encompasses value proposition and generation for the client,

- Income streams and cost structure refer to the mechanism of capturing the value by the enterprise, and this value is only an economic one (whereas in business other value types are also generated-emotional, technical ones)

- Key resources and key partners are, in fact, only one business model component

- Channel(s) for value proposition can be considered as a separate business model component.

Such aggregation of components shows that a business model is constituted by only four main elements, and some of the existing ones are too broad. This analysis also helps to conclude that the discussed business models have some flaws, as it does not include any competition-related and risk- 
related components. Nowadays, it is common knowledge that competition is a key activity in every enterprise. Therefore exclusion of competition in a business model should be considered as a significant flaw. It is also important, that the authors of a business model (canvas) do not recognize relations between individual components and with the environment.

The setting of a Polish social enterprise model is discussed in Chapter 3. Different social enterprise models throughout the EU are presented here. The social enterprise models from EU, the UK, and the USA are compared. Emerging differences in existing solutions are proposed together with flexicurity. The Danish 'golden triangle' on flexicurity is a configuration of a flexible job market, a generous social welfare system and active policies in the job market. The qualitative research results that are presented are backed up by quantitative data on social enterprise operations.

As a summary, the idea: "The end of charity: time for social enterprise" [N. Frances, 2008] is referred to. Also, the author posits that the Polish social enterprise model is represented by different local hybrid forms of social activity.

The results of empirical research are presented in the last chapter. The main task of this research was to validate the applicability of the theoretical propositions on how a business model can be used in a social enterprise description. The research objectives are put forward to meet cognitive, methodological as well as utilitarian purposes. A research social enterprise model in Poland is introduced here (Figure 10). This model includes environment, social enterprise (organizational and legal form, business model and economic activity type), effectiveness (social and economic). The Figure is accompanied by the relevant hypotheses, which leads to understanding them in a better way.

According to Polish Statistical Office data from 2014, the population in the author's study encompassed more than 134234 enterprises, and 899 social enterprises were randomly selected from this population. In the end, the response rate equaled $79.87 \%$ meaning that 718 social enterprises participated in the research. The questionnaire designed by the author helped to gather respondents' opinions about the research problem. Respondents were asked about legal-organizational form, business model, statutory goals, type of activity, economic and statutory activities, employment size, scope of statutory activity, and financial situation.

The results show that among social enterprises there is a diversity of economic activity, their financial condition is poor, their organization is weak, and a fundraising-entrepreneurial model is the most common one. It is also possible for a social enterprise, to implement more than one business model at a time. 
The research undertaken by the author leads to the creation of a holistic social enterprise model (Figure 11). The purpose of the support and reasons for the support for subjects in need are mentioned here, which deserves particular attention from the reader. Further, a conceptual social enterprise model is presented (Figure 12) where a business model and a social enterprise body of knowledge are combined. The author's achievements, allow the reviewer to recommend this book to other readers, as reference that adds to the understanding of business model concepts. The author justifies the employment of a business model concept in the analysis and a description of social enterprise activity.

The review was prepared by Tadeusz Falencikowski, (Ph.D., Eng, habilitatus, associate professor) 